\title{
INTERFERÊNCIAS DO RUÍDO DO TRÁFEGO URBANO NA QUALIDADE DE VIDA Estudo de Caso - Zona Residencial - Brasília /DF
}

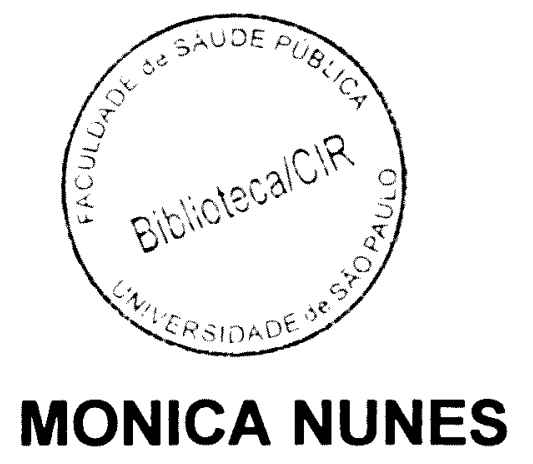

Tese de Doutorado apresentada ao Departamento de Saúde Ambiental da Faculdade de Saúde Pública da Universidade de São Paulo para obtenção de Grau de Doutor.

$$
\text { Área de concentração: Saúde Ambiental }
$$

ORIENTADOR: PROFESSORA Dra. HELENA RIBEIRO 
Autorizo, exclusivamente para fins acadêmicos e científicos, a reprodução total ou parcial desta tese, por processos fotocopiadores. Assinatura:

Data: 
Aos meus pais $e$, especialmente, aos meus filhos André e Júlia 


\section{AGRADECIMENTOS}

À Professora Helena Ribeiro, pela orientação segura, estimulo, amizade, e confiança, tornando sempre possivel o alcance da realização deste estudo.

Ao Professor Carlos Celso de Amaral e Silva, meu reconhecimento pela sua colaboração e estimulo sempre presente.

Ao Professor Gary Winkel, da City University of New York - Graduate Center of Environmental Psychology, pela sua atenção e seriedade com que me orientou no periodo de estágio nessa universidade.

Ao Professor Harmut Gunther, meus agradecimentos pelo estimulo e, em especial pela ajuda na obtenção do estágio na universidade City University of New York.

À Dra. Silvania Medeiros Gonçalves, diretora do Projeto Silêncio (IBAMA), pela amizade, colaboração e apoio instrumental para realização da pesquisa.

Aos meus pais Geraldo e Bárbara, pelo exemplo e incomensurável apoio para realização deste estudo.

Aos meus filhos André e Julia pela maturidade, compreensão e carinho com que superaram os obstáculos e meus limites ao longo deste periodo.

À colega Adelaide Nardocci pelo apoio, amizade e especial colaboração na etapa final deste estudo

À colega Cilene Victor, pelo apoio e amizade

A colega Maria de Fátima Pedrozo pela amizade e apoio ao longo do curso

A Antonio de Jesus $M$. Chaib pelo incentivo inicial para realização deste curso

Ȧ empresa NOVACAP pela oportunidade e pela confiança no investimento depositado a minha pessoa

Ao CNPQ/CAPES pela grande oportunidade e apoio financeiro para efetivação plena do curso.

À Secretaria de Meio Ambiente e Recursos Hidricos - DF, pelo apoio técnico e instrumental para realização da pesquisa

À Comissão da Pós Graduação em especial à Angela Renilda e Cidinha, pela simpatia e atenção 


\section{RESUMO}

Nunes, M. Interferências do Ruido do Tráfego Urbano na Qualidade de Vida: Estudo de Caso - Zona Residencial - Brasília/DF. São Paulo; 2000. [Tese de Doutorado - Faculdade de Saúde Pública da USP].

Objetivo. Avaliar a existência do ruido como um problema ambiental e seus possiveis efeitos na qualidade de vida e na saúde da população. Métodos. Selecionou-se uma zona residencial multifamiliar, constituida de apartamentos e lindeira a uma via de grande volume de tráfego, na cidade de Brasilia. Foram feitas medições de ruido nos niveis térreos dos blocos selecionados e nos apartamentos, com janelas abertas e fechadas. Aplicouse um questionário constituido de questões fechadas sobre percepção da qualidade ambiental urbana, sensibilidade e efeitos relacionados à exposição ao tráfego urbano. Resultados. Entre os resultados da pesquisa identificou-se que: a área de estudo é comprometida quanto ao aspecto da poluição sonora e a população sofre, diariamente, com este problema; o nivel de ruido incomoda as pessoas que moram na área e interfere na realização de atividades diárias. Conclusões. Os grupos de pessoas do sexo feminino e os de mais jovens mostraram-se mais sensiveis ao ruido e declararam sentir com maior intensidade seus efeitos negativos; consequentemente, estas pessoas sentem-se mais incomodadas que as demais quanto ao ruido urbano. Foi também identificado que existe uma expectativa de que as pessoas que menos gostam da área onde moram e pior qualificam a qualidade ambiental do lugar são as mais sensiveis, as que mais sofrem os efeitos negativos do ruido de tráfego e, ao mesmo tempo, são as menos acostumadas com o problema

Descritores: ruido. qualidade de vida. qualidade ambiental urbana. efeitos na saúde humana. percepção do ruido. 


\section{SUMMARY}

Nunes, M. - Interferências do Ruido do Tráfego Urbano na Qualidade de Vida: Estudo de Caso - Zona Residencial - Brasilia/DF Traffic Noise Interference in the life quality: Case Study - Residential area - Brasilia/DF]. São Paulo (BR); 2000. [Tese de Doutorado - Faculdade de Saúde Pública da Universidade de São Paulo].

Objective. A noise survey was undertaken in a residential area of apartment buildings, close to a street with a high traffic noise, in the city of Brasilia, to study the environmental quality and the effects associated with traffic noise exposure. Methods. A structure questionnaire was based on direct questioning about urban quality perception, sensibility and the related effects as a result of an exposure to noise traffic. The noise level was measured in the streets and inside the apartments with closed and opened windows. Results. Among the major findings of the survey it has been identified that: the noise problem exists in the area of the study and that the local population has been suffering from annoyance and interference on daily activities; youngest people and the women are the most affected and in a higher level; persons who dislike the area where they live and qualify negatively the environmental quality of the place are the most sensitive and the ones who most feel the negative effects from the traffic noise and are, also, less used to it. Conclusions. It has been verified that women and youngest people liked the area less than the others do and felt more the negative effects of the noise than the others do and, consequently, they were also more disturbed.

Descriptors: noise. Life quality. Urban environment. Health effects. Noise perceptions 


\section{ÍNDICE}

1 - INTRODUÇÃO

2 - O MEIO AMBIENTAL URBANO 3

2.1 - Conceitos 3

2.2 - Qualidade Ambiental urbana 8

2.3 - Indicadores de Qualidade de Vida 12

3 - METODOLOGIA 17

3.1 - Hipótese do Estudo 17

3.2 - Etapas do Estudo $\quad 17$

3.2.1 - Revisão Bibliográfica 18

3.2.2 - Desenvolvimento do estudo de Caso 18

3.2.3 - Medição do Ruido do Tráfego 26

3.2 .4 - Tratamento dos dados 28

4 - CIDADE DE BRASILIA 29

4.1 - Introdução 29

4.2 - Área de estudo 31

5 - O RUIDO URBANO 41

5.1 - Introdução $\quad 41$

5.2 - Percepção 43

5.2.1 - Percepção Ambiental 44

5.2.2 - Percepção Auditiva 45

5.3 - Fontes do Ruido Urbano 47

5.4 - Caracteristicas do Ruido do Tráfego Urbano 49

5.5 - Controle da Emissão do Ruido do Tráfego Urbano 52

5.6 - Efeitos do Ruido do Tráfego urbano 54

5.7 - Legislação 56

6 - ANÁLISE DOS EFEITOS DO RUIDO DO TRÁFEGO URBANO NA SAÚDE HUMANA 62

7- RESULTADOS 76

7.1 - Estudo de Associações entre Variáveis $\left(\chi^{2}, p\right) \quad 76$

$\begin{array}{ll}7.1 .1 \text { - Perfil da população } & 76\end{array}$ 
$\begin{array}{ll}7.1 .2 \text { - Perfil da residência } & 78\end{array}$

7.1 .3 - Avaliação ambiental da área de estudo 79

7.1.4 - Sensibilidade e Percepção do Ruido do Tráfego urbano 84

7.1 .5 - Efeitos do Ruido de Tráfego 94

7.1.6 - Caracterização do Grupo mais Atingido pelo Problema 102

7.2 - Análise Canônica dos Dados 106

7.3 - Medições do Ruido do Tráfego na Área de Estudo 109

8 - DISCUSSÃO 112

8.1 - Niveis de Ruido Encontrados na Área de Estudo 112

8.2 - Qualidade Ambiental da Área de Estudo 113

8.3 - Sensibilidade e Percepção do Ruido do Tráfego Urbano 114

8.4 - Efeitos do Ruido do Tráfego Urbano 116

8.5 - Caracterização do Grupo que Sofre Maiores Impactos 117

9 - CONCLUSÃO 121

9.1 - Análise das Hipóteses 122

9.2 - Recomendaçōes $\quad 124$

10 - REFERENCIAS 126

ANEXOS

Anexo 1 - Brasilia, Setorização

Anexo 2 - Questionário da pesquisa 


\section{LISTA DE TABELAS}

Tabela 1 - Volume de tráfego das vias existentes frente às zonas residenciais.

Tabela 2 - Resumo da população americana exposta ao nível médio de ruído diário.

Tabela 3 - Limites máximos de emissão de ruido para veículos automotores na cidade de Brasilia.

Tabela 4 - Distribuição da amostra por faixa etária.

Tabela 5 - Distribuição da amostra por bairro e faixa etária. 76

Tabela 6 - Distribuição por nivel escolar.

Tabela 7 - Distribuição por nível escolar e faixa etária.

Tabela 8 - Distribuição da amostra por tempo de residência na área. 77

Tabela 9 - Distribuição por tempo de residência na área e faixa etária. 78

Tabela 10 - Distribuição da amostra por andares de apartamento . 78

Tabela 11 - Distribuição por número de pessoas por apartamento. 79

Tabela 12 - Distribuição pela opção em gostar ou não da área onde reside.

Tabela 13 - Distribuição pela opção de gostar da área onde reside por faixa etária.

Tabela 14 - Distribuição pela opinião de gostar ou não da área onde reside por tempo de residência (agrupados em $>4$ anos e $\geq 4$ anos)

Tabela 15 - Distribuição das características que mais gostam na área

Tabela 16 - Distribuição da Amostra segundo indicações das caracteristicas que menos gostam na área

Tabela 17 - Distribuição segundo avaliação da qualidade ambiental da cidade

Tabela 18 - Distribuição da avaliação da qualidade ambiental da cidade por sexo

Tabela 19 - Distribuição da avaliação da qualidade ambiental da área onde vive 
Tabela 20 - Distribuição da avaliação da qualidade ambiental da área por tempo de residência

Tabela 21 - Distribuição da avaliação de características ambientais

Tabela 22 - Distribuição da amostra segundo prioridades adotadas em caso de escolha da área onde viriam morar

Tabela 23 - Distribuição por tempo de permanência em casa nos dias úteis

Tabela 24 - Distribuição segundo o tempo de permanência em casa nos dias úteis e a variável sexo

Tabela 25 - Distribuição segundo tempo de permanência em casa (horas) nos dias úteis por faixa etária

Tabela 26 - Distribuição do tempo de permanência em casa no final de semana

Tabela 27 - Distribuição segundo nivel de sensibilidade ao ruido

Tabela 28 - Distribuição segundo avaliação do próprio apartamento quanto ao nivel de barulho

Tabela 29 - Distribuição da amostra segundo avaliação do próprio apartamento quanto ao nivel de barulho por sexo

Tabela 30 - Distribuição segundo avaliação do apartamento quanto ao nivel de barulho por faixa etária com apenas três alternativas de respostas

Tabela 31 - Distribuição da amostra segundo avaliação do próprio apartamento quanto ao nivel de barulho por bairro

Tabela 32 - Distribuição segundo as pessoas que se assustam com o barulho

Tabela 33 - Distribuição das pessoas que se assustam com o barulho e a variável sexo

Tabela 34 - Distribuição segundo o costume de fechar as janelas ao longo do dia

Tabela 35 - Distribuição do costume da amostra de fechar as janelas ao longo do dia por faixa etária agrupadas em $<60$ e $60=>89$

Tabela 36 - Distribuição da amostra segundo identificação de incômodo 
provocado pelo barulho

Tabela 37 - Distribuição segundo identificação de incômodo provocado pelo barulho por faixa etária

Tabela 38 - Distribuição da Amostra segundo identificação do nivel de incômodo provocado pelo barulho

Tabela 39 - Distribuição da amostra segundo identificação do nivel de incômodo provocado pelo barulho por sexo

Tabela 40 - Distribuição da amostra segundo identificação do nivel de incômodo provocado pelo barulho por faixa etária

Tabela 41 - Distribuição da amostra segundo identificação do nivel de incômodo provocado pelo barulho por faixa etária, agrupando-a em intervalos de idade $<60$ e $>=60$ anos.

Tabela 42 - Distribuição da amostra segundo identificação dos dias de maior incômodo durante a semana

Tabela 43 - Distribuição segundo identificação dos periodos de maior incômodo ao longo do dia

Tabela 44 - Distribuição segundo a referência de estar acostumado com o ruido do tráfego

Tabela 45 - Distribuição segundo o costume com o ruido do tráfego, por sexo

Tabela 46 - Distribuição segundo identificação de interferência do ruido em atividades diárias

Tabela 47 - Distribuição segundo opção de atividades que sofrem maior interferência pelo ruido de tráfego

Tabela 48 - Distribuição segundo a identificação de interferência do ruido de tráfego na atividade de ouvir som, radio e TV.

Tabela 49 - Distribuição segundo a identificação de interferência do ruido de tráfego na atividade de ouvir som, rádio e TV, por sexo

Tabela 50 - Distribuição segundo a identificação de interferência do ruido de tráfego na atividade de leitura

Tabela 51 - Distribuição segundo a identificação de interferência 
do ruido de tráfego na atividade de falar

Tabela 52 - Distribuição da amostra segundo a identificação de interferência do ruido de tráfego na atividade de dormir

Tabela 53 - Distribuição segundo a identificação de interferência do ruído de tráfego na atividade de leitura por faixa etária

Tabela 54 - Distribuição segundo a identificação de danos causados pelo ruido do tráfego à saúde do entrevistado

Tabela 55 - Distribuição segundo os danos causados pelo ruido do tráfego à saúde do entrevistado por sexo

Tabela 56 - Distribuição segundo os danos causados pelo ruído do tráfego à saúde do entrevistado por faixa etária

Tabela 57 - Distribuição segundo a identificação de danos causados pelo ruido do tráfego à saúde da familia do entrevistado

Tabela 58 - Distribuição segundo a identificação de danos causados pelo ruido do tráfego à saúde da familia do entrevistado por sexo

Tabela 59 - Distribuição da identificação de danos causados pelo ruido do tráfego à saúde da familia do entrevistado por faixa etária.

Tabela 60 - Distribuição da identificação da existência de áreas residenciais piores, quanto à presença do ruido causado pelo tráfego urbano.

Tabela 61 - Distribuição segundo a existência de perspectiva de redução do nivel de ruido de tráfego na área de estudo.

Tabela 62 - Distribuição segundo a existência de perspectiva de redução do nivel de ruido de tráfego na área de estudo por sexo.

Tabela 63 - Distribuição segundo a existência de perspectiva de redução do nivel de ruido de tráfego na área de estudo por faixa etária.

Tabela 64 - Distribuição da amostra segundo o nivel de sensibilidade ao ruido e a identificação do nivel de barulho do 
apartamento.

Tabela 65 - Distribuição segundo o nivel de sensibilidade ao ruido e a identificação de incômodo com o ruido de tráfego.

Tabela 66 - Distribuição segundo o nivel de sensibilidade ao ruído e a identificação do incômodo com o ruido de tráfego.

Tabela 67 - Distribuição segundo o nivel de barulho do apartamento e a identificação do incômodo com o ruido de tráfego.

Tabela 68 - Distribuição segundo a interferência em atividades diárias e o nivel de sensibilidade ao ruido.

Tabela 69 - Distribuição segundo a interferência em atividades diárias e a identificação de incômodo.

Tabela 70 - Distribuição segundo a interferência em atividades diárias e o nivel de incômodo provocado pelo ruido do tráfego urbano.

Tabela 71 - Correlações, Coeficientes Canônicos Padrōes, Correlações Canônicas, Percentuais de Variância e Redundância entre as variáveis do perfil da amostra e os efeitos do ruido urbano na qualidade de vida.

Tabela 72 - Niveis de ruido (leq) medidos na área de estudo período manhã 


\section{1- INTRODUÇÃO}

A pesquisa aborda a qualidade ambiental urbana da cidade de Brasilia e insere uma análise especifica do ruido do tráfego urbano: como problema, indicador da qualidade ambiental da cidade e causador de possiveis efeitos sobre a saúde da população.

O estudo apresenta, inicialmente, uma discussão teórica sobre a problemática urbana e sua interface com a questão ambiental. São discutidos os vários conceitos sobre o meio ambiente urbano, qualidade ambiental $\mathrm{e}$ os indicadores que vêm sendo adotados como critério e metodologia de análise em sua avaliação.

É apresentado um perfil da cidade de Brasília, selecionada por ser uma cidade planejada que atenderia não apenas aos objetivos especificos da pesquisa mas também forneceria uma análise paralela que permitisse verificar se o planejamento urbano adotado teria inserido e alcançado as metas para um controle ambiental adequado.

A pesquisa consiste em uma avaliação ambiental, em campo, que envolve o comportamento humano em suas atividades diárias. Assim, o desenvolvimento dos instrumentos da pesquisa, tais como seleção da amostra, área de estudo, elaboração do questionário e metodologia de aplicação, foi fundamentado na área da psicologia ambiental.

A psicologia ambiental é, hoje, uma área onde é encontrada a grande maioria das pesquisas que envolvem a relação homem e ambiente considerando seu comportamento diante da percepção e da imagem que ele apreende do seu meio. O desenvolvimento desta pesquisa na área da psicologia foi determinado pelas limitaçōes observadas em estudos experimentais, em laboratório, que criam situações pré-definidas e portanto irreais para análises do comportamento humano. A metodologia do estudo em campo mostra-se mais apropriada para o exame dos aspectos fisicos do meio ambiente em sua forma natural. Proshansky (1995, p.61), citado por Bonnes et Secchiaroli, 1995) faz críticas aos estudos de laboratório que, segundo ele, descaracterizam a questão quando apresentam a reprodução 
de uma situação limitada com a eliminação de inúmeros fatores necessários para a análise; consequentemente os resultados não podem ser generalizados nem adotados para as situações similares que, entretanto, ocorrem em condições reais no espaço urbano. Neste contexto os estudos, em sua maioria, são desenvolvidos em campo através de uma avaliação perceptiva da amostra em análise.

Adotou-se como fonte de dados a percepção e o comportamento da amostra, residentes em uma zona multifamiliar, frente aos problemas ambientais provocados pelo ruido do tráfego. Para obtenção desses dados foi desenvolvido um questionário com rigoroso critério na elaboração das questōes, definição de escalas de respostas, linguagem e conteúdo. Buscou-se, ainda, minimizar a subjetividade na compreensāo e interpretação do mesmo para garantir resultados que demonstrassem o comprometimento da área de estudo quanto ao aspecto da poluição sonora e os efeitos negativos provocados na população da amostra, decorrentes da exposição diária ao ruido. 


\section{2 - O MEIO AMBIENTE URBANO}

\section{1- Conceitos}

O objetivo deste capitulo é discutir sobre o conceito de alguns termos que são utilizados para definir o espaço urbano, em todas as suas dimensões, como meio ambiente. O esclarecimento sobre os significados e conceitos desses termos é importante para melhor entende-los e, consequentemente, definir e conhecer o que pode ser adotado como variáveis ambientais urbanas.

Considerando a literatura sobre 0 assunto, observa-se a utilização dos termos meio ambiente urbano e ecossistema urbano para a descrição do espaço da cidade de uma forma holistica. Entretanto esses termos têm sido frequentemente utilizados como termos genéricos, politicos e subjetivos. Esse fato tem impedido uma melhor compreensão sobre seus conteúdos, quando se referem aos problemas reais que são atualmente detectados nas áreas urbanas.

Considerando o aspecto histórico, o termo ambiente começou a ser utilizado no periodo da Arte Pop americana para representar, de forma simbólica, o ambiente construido desvinculado de suas caracteristicas estéticas. Esse termo foi importado pela Europa com um conceito diferente, e foi adotado pela arquitetura para referir-se aos espaços novos construidos que tivessem o poder de estruturar a sua própria utilização e o seu entorno. Nas Ciências Humanas, a utilização do termo superou a questão estética e funcional e foi adotado com um sentido semelhante ao definido pela arquitetura; entretanto o seu significado não era restrito apenas à paisagem urbana, mas a uma estrutura construída com poder social (Cutter, 1985).

A Organização Mundial de Saúde, em 1972 (WHO, 1972), já reconhecia que a cidade não seria somente um meio no qual as pessoas vivem, mas englobaria também o sistema fisico e social juntamente com seus efeitos diretos e indiretos sobre a saúde humana.

A cidade deve ser vista como sendo composta de duas partes: o meio ambiente natural - lugar, geologia, clima e o meio ambiente criado - 
edificaçōes, ruas e outros componentes da morfologia urbana. Esses ambientes fisicos estariam envolvidos com as condições: forças e fatores demográficos, sociais, econômicos, culturais e politicos especificos de cada área urbana (WHO, 1972).

Ecossistema urbano é outro termo também utilizado para referir-se ao espaço urbano. O seu conceito tem sido desenvolvido desde a década de 1960. A cidade, como um ecossistema, é imaginada como um espaço que envolve relaçōes complexas entre a atividade humana e o meio ambiente. $O$ termo ambiente foi, também, abordado por varias áreas cientificas: primeiramente foi elaborado por sistemas teóricos e ecológicos e posteriormente discutido por cientistas de outras áreas, entre eles: arquitetos, antropólogos e geógrafos (Brugman, 1992).

Segundo Brugman (1992) a cidade pode ser imaginada como um ecossistema, entretanto ela apresenta seis caracteristicas que a diferencia do ecossistema natural: 1) densidade populacional humana, 2) manipulação e regulação do ambiente físico, material e do fluxo de energia; 3) condição de intenso contato competitivo entre membros de uma mesma espécie; 4) ecossistema novo, caracterizado pela presença de ciclos abertos 5) alta intensidade de energia, para suprir a concentração populacional $\mathrm{e}$ as atividades produtivas; 6) maior intensidade de comunicação e informação do que a apresentada pelos ecossistemas naturais.

Exline et al. (1982) propõem uma divisão do ecossistema urbano em dois subsistemas: o subsistema físico e o cultural. O subsistema físico poderá ser dividido em subsistemas menores, incluindo os seguintes: geológico, climático, hidrológico e biológico, no entanto todos eles são considerados interdependentes, interagindo entre si de forma complexa.

Os aspectos geológicos e topográficos, mesmo em grandes cidades, são os fatores limitantes para o crescimento urbano e sua expansão urbana, quando não for possivel superá-los com tecnologia e recursos financeiros

Quanto ao aspecto climático, o ecossistema urbano apresenta, pelo menos, cinco caracteristicas, diferentes daquelas encontradas no meio 
rural, tais como: primeira, a diferença considerável entre as superficies da cidade e a rural - a grande presença do concreto nas cidades além de absorver e armazenar uma grande quantidade de calor inibe o crescimento de vegetação; segunda, a superficie da cidade é bem mais rugosa, em decorrência da verticalização dos edificios que aumenta a absorção do calor e interfere no direcionamento e na velocidade dos ventos; terceira, o aquecimento é afetado pelo impacto do ecossistema urbano nas águas de superficie e a carência de áreas verdes gera a predominância de superficies impermeáveis, como o concreto, que acentuam a velocidade de escoamento superficial das águas de chuva e diminuem o processo de evaporação, produzindo um maior aquecimento das cidades; quarta, a presença da energia e do calor gerados pela própria população da cidade através de suas atividades diárias; e, finalmente, a quinta caracteristica refere-se aos impactos negativos na atmosfera decorrentes da presença dos poluentes na cidade.

Quanto ao aspecto hidrológico é identificada a intensidade dos impactos das áreas urbanas. A impermeabilização da superficie do solo urbano, como já foi citada, ocasiona um aumento na frequêencia e na magnitude dos fluxos de água gerando uma grande elevação do coeficiente do escoamento superficial. Esse fato cria uma grande preocupação no controle dos problemas de drenagem das águas de chuva para evitar as inundações.

No aspecto biológico, verifica-se a influência da vegetação urbana que, além de ser um aspecto importante na estética do ecossistema, atua na transpiração e gera a alteração climática do meio.

Perloff (1973) propōe que antes que se faça qualquer interferência no ambiente urbano de áreas metropolitanas deve-se subdividi-lo em cinco campos de análise, utilizando-se as seguintes abordagens: meio ambiente natural, meio ambiente espacial, meio ambiente dos serviços de transporte, meio ambiente da comunidade vicinal e o micro meio ambiente: 
- o meio ambiente natural compreende o estudo da qualidade do ar, da água, espaços para recreação, zonas tranqüilas, ruidosas, com odores, microclimáticas e a situação da exposição solar das edificações;

- o meio ambiente espacial envolve um estudo onde são consideradas a caracterização e a análise do espaço subterrâneo, do solo e do espaço aéreo, em termos de normas e eficiência de uso;

- o meio ambiente dos serviços e transporte envolve considerações e estudos sobre a distribuição de água, telefone, eletricidade, sistema de drenagem e a própria rede de transportes. A acessibilidade aos lugares é básica em muitos aspectos do meio ambiente; neste último item, deve-se abordar desde a disponibilidade do transporte de massa e outras formas de transporte, até os dados referentes ao tempo de viagem, ao congestionamento, à segurança e à tensão;

- o meio ambiente da comunidade vicinal deve abordar elementos, diferenciados, como: áreas pobres, áreas de centro de cidades, áreas suburbanas e entorno;

- o micro meio ambiente será constituido da familia, do lugar de trabalho, sendo esse o cenário das relações mais intimas do individuo.

Já segundo Branco (1989), a cidade não pode constituir um ecossistema verdadeiro, uma vez que não compreende uma atividade de produção ou fixação de energia primária. Ela recebe um fluxo contínuo de energia e matéria, combustiveis, matérias - primas e alimentos provenientes de áreas externas, caracterizando-a como unidirecional, não havendo retorno e, consequentemente, não cíclica. Esse processo contraria, fundamentalmente, os fluxos de matéria característicos da biosfera.

Diante da variedade de conceitos e abordagens citadas, observa-se que existem ainda grandes discussões sobre o que deve ser entendido como meio ambiente ou ecossistema urbano. O mesmo já não se aplica ao termo "meio ambiente natural", que tem seu conceito científico próprio na área da ecologia e claramente definidos seus impactos e suas variáveis.

Constata-se, portanto, nesta discussão de conceitos, uma grande preocupação em diferenciar o meio ambiente urbano ou ecossistema 
urbano do conceito ecológico do meio ambiente natural e, também, do meio ambiente rural. Busca-se encontrar, na conceituação de ecossistema urbano ou meio ambiente urbano, a analogia, interação e procedimentos similares àqueles definidos na área das ciências naturais especialmente na biologia. $O$ fato de o meio ambiente urbano e o meio natural apresentarem similaridades e não serem idênticos quanto aos seus fluxos, tem gerado muita discussão na área acadêmica onde se questiona se ambos podem ou não ter uma análise paralela. Embora esse seja um questionamento importante, ele tem inibido o desenvolvimento de estudos das especificidades do próprio meio ambiente urbano, para que seja definida sua ciência multidisciplinar.

A cidade, ao ser considerada um meio artificial, construida pela ação humana, apresenta suas particularidades históricas, sociais, econômicas e culturais. Não se tem, portanto, um modelo único para caracterizá-la. Esse fato cria, consequentemente, uma situação complexa para a caracterização genérica de um modelo para análise. Portanto o termo meio ambiente encontra-se sujeito a uma interpretação cientifica disciplinar.

A dimensão e complexidade do termo meio ambiente urbano têm gerado dificuldades nas tentativas de identificar, racionalizar e medir a intensidade das variáveis ambientais e de seus impactos. Entretanto é urgente o combate à deterioração das condições urbanas que, em muitos casos, particularmente em paises em desenvolvimento, têm atingido proporções de crise.

Todas as áreas, atualmente, destacando-se as da saúde, do planejamento, da geografia, da psicologia e do urbanismo, consideram a questão ambiental importante e essencial para as cidades. É fundamental encontrar soluções para a redução dos impactos negativos do processo de urbanização, que já ocorreram e que ainda se desenvolvem atualmente nas cidades, de modo a garantir uma qualidade ambiental aceitavel para a população. 


\section{2 - Qualidade Ambiental Urbana.}

Diante do desenvolvimento de estudos das características do meio ambiente urbano, têm sido desenvolvido, paralelamente, critérios para análise e avaliação da qualidade de vida oferecida à comunidade, tendo-se como referência o bem-estar do ser humano.

No processo de análise e avaliação do meio ambiente urbano, vem sendo adotada como critério a necessidade do atendimento a um determinado padrão de qualidade ambiental para proporcionar um bom nivel de qualidade de vida. Entretanto tem-se, como desafio, neste tipo de análise, a elaboração dos conceitos do que seja qualidade ambiental urbana padrão e qualidade de vida. Ambas as variáveis vêm sendo utilizadas como instrumentos de medição e controle do meio urbano.

Esta etapa, que talvez seja a mais delicada e importante em um estudo do meio ambiente, torna-se complexa quando se estende a discussão sobre quais fatores e quais prioridades devam ser consideradas na elaboração de um conceito de qualidade de vida padrão para uma determinada comunidade. Ela envolve a definição de elementos que seriam adotados como indicadores de qualidade de vários aspectos presentes no meio urbano e seriam, também, aqueles que interfeririam de modo positivo ou negativo no meio ambiente de uma determinada população.

Considerando a caracteristica holística de uma abordagem ambiental, pode-se prever o uso de critérios subjetivos, diante das especificidades culturais, sociais e econômicas de uma determinada população, pois os componentes do meio urbano vão além de suas caracteristicas físicas e bióticas.

A Organização Mundial de Saúde-OMS desenvolveu um projeto, denominado "Organização Mundial de Saúde - Avaliação da Qualidade de Vida" (WHO, 1994b), que teve como meta obter um critério de avaliação internacional de qualidade de vida. Admitindo não haver um consenso sobre o que seja qualidade de vida, são abordadas caracteristicas já aceitas por pesquisadores na construção de seu conceito de qualidade de vida. Entre 
elas admite-se qualidade de vida como subjetiva, multidimensional, com aspectos positivos e negativos.

A subjetividade apresentaria dois niveis de análise: a percepção de condições objetivas, sendo elas materialmente representadas e a percepção de condições subjetivas que envolve uma avaliação pessoal quanto ao nivel de satisfação com os recursos. Admitindo-se esta característica da subjetividade, a avaliação da qualidade de vida seria favorecida, pois haveria uma maior racionalização na elaboração de questões a serem aplicadas em um estudo e na análise dos resultados, considerando essas diferenças perceptivas que ocorrem na obtenção das respostas na aplicação de pesquisas.

A qualidade de vida é considerada multidimensional por envolver dimensões físicas, psicológicas, sociais e religiosas. Neste aspecto são consideradas, respectivamente, as percepções individuais do estado físico, cognitivo e afetivo, das relaçōes sociais e, por último, das crenças pessoais que estruturam e qualificam experiências. Ela abrange, também, a consideração de dimensões positivas e negativas.

Um dos fatores que dificulta a definição do que seja um padrão ideal de qualidade de vida é a identificação das necessidades sociais as quais têm um forte vinculo com os aspectos histórico, cultural, econômico e também com a percepção e julgamento de prioridades de uma população especifica. Logo, a determinação de um padrão de qualidade de vida caracteriza-se pela presença da subjetividade, sendo dependente de caracteristicas sociais, culturais e econômicas de grupos distintos que estabelecem sua própria hierarquia de necessidades, de modo a atender suas preferências, tradiçōes e modo de vida

Segundo Frick (1986), a qualidade de vida urbana envolve um aspecto objetivo e outro subjetivo. Objetivamente, ela pode ser medida através dos niveis de saúde mental e fisica da população de uma determinada área. Subjetivamente, a presença ou ausência de qualidade de vida urbana será medida através do julgamento resultante de uma 
associação da percepção e da experiência daqueles que vivem, trabalham e visitam a cidade ou vizinhança.

Há, também, abordagens distintas sobre a questão, sendo esta uma situação semelhante à da discussão do conceito de meio ambiente urbano. Consequentemente, os conceitos de qualidade ambiental urbana e de qualidade de vida estão sujeitos a interpretações científicas disciplinares e vários vêm, portanto, sendo definidos com abordagens disciplinares especificas.

Segundo Cutter (1985), conceitua-se qualidade de vida, na escala individual, como felicidade ou satisfação própria com a vida e o ambiente, incluindo necessidades, desejos e preferências de estilo de vida e outros fatores que determinam o bem estar do individuo. Para a comunidade, este conceito estaria vinculado às especificidades do grupo, ou melhor, às condições sociais e ambientais existentes, refletindo um consenso local de valores e metas.

Segundo a OMS, a qualidade de vida constrói-se através da percepção individual de sua condição de vida, inserida no seu contexto cultural e em seu sistema de valores, tendo como referência suas metas, expectativas, padrões e interesses (WHO, 1994b).

Os geógrafos incorporam à qualidade de vida o bem estar do individuo. Entretanto dão maior importância às características do lugar, considerando as medições objetivas e subjetivas de condições ambientais e sociais que são vivenciadas pela população. Três dimensões são consideradas importantes: a social, a ambiental e a perceptiva. Cada dimensão inclui critérios de medições e avaliações através de indicadores, da variável mais objetiva à mais subjetiva. Entretanto todas elas estariam inter-relacionadas: a dimensão social considera, como condições objetivas do ambiente social, entre outros, a habitação, renda e a violência; a dimensão ambiental leva em conta as caracteristicas físicas, como o clima, a poluição, a recreação etc.; a terceira dimensão, a perceptiva, avalia a relativa importância das condições objetivas através da definição subjetiva 
da imagem do ideal para o indivíduo e de suas expectativas sobre o lugar (Cutter, 1985).

O critério mais comum de avaliação da qualidade de vida das cidades, empregado pela Saúde Pública, é a utilização de indicadores tais como: indices de morbidade, mortalidade, expectativa de vida, incidência de doenças infecciosas e não infecciosas. A cidade não é considerada somente como o ambiente no qual as pessoas vivem, mas como um sistema físico e social com efeitos diretos e indiretos sobre a saúde humana e há a preocupação com o controle dos processos quimicos, físicos e biológicos e de influências e fatores que exerçam ou possam vir a exercer efeitos significativos na saúde fisica e mental e no bem-estar social do homem, em sua sociedade. Apresenta duas metas de atuação: uma é a corretiva, com a eliminação de riscos para a saúde humana no meio ambiente, e a segunda é a preventiva, que busca o gerenciamento dos recursos ambientais da área urbana, para promover o bem estar e evitar os riscos

No planejamento urbano, a densidade urbana está relacionada ao conforto fisico e ao custo administrativo da manutenção da cidade. Observa-se a preocupação e a consciência de planejadores com as medidas de controle do crescimento urbano e da avaliação da qualidade de vida utilizadas nos paises desenvolvidos. Entretanto nem sempre essas medidas são adequadas para os paises em desenvolvimento, diante das diferenças socioculturais e financeiras.

Observa-se que quando é levantada a questão sobre o que deve ser feito para a melhoria da qualidade da vida urbana, são abordados diferentes aspectos, revelando os diferentes significados implicitos em seu conceito, que classificam, desde o nivel de oferta de serviços adequados para a população - preocupações com os problemas econômicos, como emprego, renda e desenvolvimento econômico, referências de nivel de saúde - até o interesse no nivel de satisfação da vida familiar e outras interações sociais e culturais.

Existem discussōes de que também a qualidade de vida urbana depende, principalmente, da qualidade das relações sociais em uma

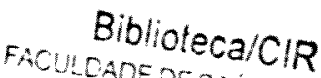

$$
\begin{aligned}
& \text { UNMERTIOADE DALDE PUBUICA }
\end{aligned}
$$


comunidade. Para as pessoas que vivem na cidade a qualidade de vida parece ser mais afetada por suas relações sociais do que pelo meio ambiente físico.

Já Proshansky (1986) coloca não haver sentido em tentar buscar um conceito comum e unificado para qualidade de vida urbana. A natureza da vida urbana, sua população, grupos sociais, instituições, atividades, objetivos e metas requerem que o conceito de qualidade de vida seja multidimensional. Segundo ele, qualidade de vida urbana deve ser, necessariamente, objeto de estudo de vários grupos tais como, cientistas, arquitetos, planejadores, geógrafos e pelo próprio governo, estando, entretanto de acordo com o aspecto da vida urbana que cada um deles defina como essencial.

\section{3- Indicadores de qualidade de vida}

Atingir um consenso do que seja qualidade de vida é difícil e um acordo universal na definição de indicadores necessários para conceituá-la torna-se também complexo.

A definição de indicadores ambientais a ser considerada, em uma avaliação será sempre dependente do conceito que foi adotado para o que seja qualidade ambiental urbana. Portanto o caráter subjetivo da conceituação de qualidade de vida urbana reflete a mesma complexidade encontrada na definição das variáveis a serem adotadas na etapa de avaliação do meio ambiente urbano.

Por um lado, existem, também, criticas à utilização de indicadores de qualidade ambiental como parâmetros universais, em virtude, muitas vezes, da subjetividade do individuo, ou melhor, das particularidades dos individuos, em sua percepção e critério de hierarquia, quanto à natureza das necessidades e também particularidades próprias das áreas urbanas.

Por outro lado, alguns autores já adotam as questões da subjetividade e a percepção como fatores importantes. 
Segundo Perloff (1973), a palavra indicador é utilizada normalmente para descrever a condição de um único elemento que seja parte de um complexo inter-relacionado, tendo como exemplos: poluição atmosférica, espaços disponiveis, nivel de ruido etc. .

Considerando a inserção de três dimensões em sua conceituação de qualidade de vida, Cutter (1985) subdivide, da mesma forma, os indicadores em: indicadores sociais, ambientais e perceptivos.

Os indicadores sociais são aqueles que se referem ao bem estar sociocultural da população, incluindo variáveis como: composição populacional, emprego, renda, educação, saúde, segurança, habitação, transporte, ambiente físico, mobilidade social e expectativa de vida.

Os indicadores ambientais representam o nivel de poluição ambiental e estão divididos em duas categorias principais: nivel aceitável e nivel de periculosidade, aquele seria para fazer uma comparação do nivel de poluição do ambiente com os padrões aceitáveis e este compara o potencial de risco e a periculosidade com relação a saúde humana.

Os indicadores perceptivos são utilizados para obter-se conhecimento do bem estar e das condições de vida do individuo ou de uma determinada população. Têm como fonte de dados a percepção de um determinado grupo em relação à qualidade de vida que decorre de suas prioridades, valores e da própria capacidade de percepção.

Entretanto a mesma autora ( Cutter, 1985) levanta criticas, em outros aspectos, quanto à limitação dos indicadores. É comum, nesses estudos, o envolvimento de variáveis não quantificáveis, utilização de censos com dados não atualizados, uso de metodologias e seleção de variáveis diferentes na obtenção final dos dados. Questōes também são discutidas quanto ao poder de representatividade e abrangência das variáveis utilizadas para definir-se a qualidade de vida urbana de uma determinada cidade. Todos esses fatores podem impedir estudos comparativos entre áreas de estudo diferentes. Eles podem causar dificuldades para definições de padrões e quantificação de indicadores para uma avaliação final da qualidade de vida urbana. 
Perloff (1973) propõe uma metodologia de análise e avaliação do meio ambiente urbano que envolve várias etapas. Primeiramente, a construção de indicadores significativos das condições atuais buscando uma padronização para as condições ideais. A etapa posterior consiste em avaliar os custos referentes à manutenção do meio ambiente na situação presente e uma avaliação de custo que implicaria na permanência das insuficiências do meio. Outra, consiste na elaboração de uma estimativa de custos para solucionar apenas os problemas ambientais. A última etapa é uma avaliação do custo para o alcance dos padrões ideais e de beneficios definidos para aquele meio ambiente.

Concluindo, Perloff (1973) propõe uma metodologia de análise e avaliação ambiental construida, primeiramente, de indicadores significativos da situação real considerando, paralelamente, referenciais padrões para situações ideais. Utilizando ambas as variáveis, ele propõe uma análise de custo beneficio para avaliar a necessidade de interferência ou não no problema. Ele propõe, essencialmente, um modelo de tomada de decisões destacando, principalmente, o estado real do problema, considerando os custos necessários envolvidos ou o que é necessário para que sejam atingidos os niveis desejáveis (Perloff, 1973). Entretanto ele próprio assume não ser fácil a determinação de indicadores padrões. A presença da subjetividade dificulta a sua construção, pelo número de diferentes opiniões e reações de individuos distintos, tanto físicas como psicológicas, sobre uma mesma situação.

Portanto as ações de politica ambiental devem ser realizadas não apenas com respeito a diversas classes da comunidade de uma metrópole, mas considerando também os diversos grupos quanto à idade, renda, raça e etnia e niveis de educação. Estas ações são necessárias para tentar-se uma caracterização e uma identificação uniforme de um determinado grupo, minimizando-se assim a subjetividade na construção de indicadores

Como foi exposto, mesmo a conceituação do meio ambiente urbano, a seleção de suas variáveis e os critérios de análises são amplos e especificos em muitas áreas do estudo. Entretanto esses estudos inter- 
relacionam-se, na medida em que muitas vezes são selecionadas para análise variáveis semelhantes em diferentes pesquisas, criando assim a composição multidisciplinar caracteristica do meio ambiente.

Outro fator observado é que um determinado meio urbano possui suas próprias especificidades e características físicas, como a formação histórica, social, cultural e econômica de sua população.

Estudos vêm sendo realizados, buscando uma maior compreensão da relação entre a população e seu meio ambiente urbano.

Bonnes et al. (1991) desenvolveram um estudo utilizando-se de uma metodologia de trabalho multidisciplinar, buscando uma abordagem integral do ecossistema da cidade de Roma. Nesse estudo, profissionais de várias especialidades direcionaram e definiram as variáveis a serem analisadas, tendo-se como proposta três abordagens paralelas: obtenção do nível de compreensão e conhecimento do caráter funcional e administrativo da cidade e identificação de áreas preferenciais para residência; análise da qualidade ambiental de áreas urbanas através da seleção de indicadores, como energia, abastecimento de água, oferta de transporte e poluição sonora; e, por último, uma avaliação perceptiva das caracteristicas sociais e fisicas de determinadas áreas ( centro, zona residencial, periferia).

Observa-se que todos os dados são obtidos diretamente com a população através de sua própria percepção e avaliação individual das questōes. Bonnes, portanto, obtém resultados amplos e ricos, diante da abrangência de variáveis, utilizando-se de critérios diferenciados na etapa de obtenção dos dados.

Há um volume significativo de literatura referente a modelos de análise do meio ambiente urbano. Existem, também, várias definições sobre o que sejam indicadores ambientais e critérios de medição da qualidade ambiental urbana. Entretanto não são encontrados na literatura exemplos de aplicação desses modelos a uma determinada realidade, com indicadores próprios e representativos da questão ambiental. Tem-se ainda uma discussão basicamente teórica sobre o assunto que requer aplicações práticas para serem comprovadas. A necessidade de estudos minuciosos 
sobre as cidades brasileiras é urgente, considerando ser o Brasil um país em desenvolvimento que apresenta caracteristicas urbanas bem diferenciadas dos paises desenvolvidos. As grandes cidades brasileiras vêm apresentando um crescimento cada vez mais intenso e desordenado, provocando uma desocupação do meio rural e atuando como pólos atrativos para populaçōes de regiões mais pobres.

Esses estudos devem iniciar-se, primeiramente, com a caracterização do meio ambiente urbano, considerando sua história, o quadro sócioeconômico e cultural da população, seus aspectos fisicos, recursos disponiveis, elementos poluentes etc., buscando uma abordagem holistica. A importação de definições de problemas ambientais urbanos, conceituadas em paises desenvolvidos, pode gerar conflitos e discrepâncias com o quadro real existente nas cidades brasileiras, considerando o nivel diferenciado de desenvolvimento e, principalmente, o fator cultural especifico de cada nação.

Observa-se a necessidade de estudos para melhor caracterização das cidades brasileiras, na busca da definição de variáveis que possam ser adotadas como indicadores ambientais especificos de sua realidade Posteriormente, será necessário um desenvolvimento de pesquisas sobre cada um desses indicadores, utilizando-se tanto mediçōes técnicas, para comprovar a sua existência e sua dimensão no meio urbano, como a utilização de avaliações perceptivas da população quanto à sua presença dentro dos valores da comunidade. Deverão ser consideradas as características socioculturais e econômicas do grupo e a intensidade e freqüência de danos à saúde humana em seu meio.

A implantação de modelos para a análise e avaliação qualitativa do meio ambiente urbano deverá consistir, portanto, em uma etapa posterior, na priorização das intervenções necessárias para neutralizar ou reduzir os impactos negativos que mais afetam a comunidade. 


\section{3 - METODOLOGIA}

\section{1 - Hipóteses do Estudo}

O desenvolvimento desta pesquisa tem como objetivos: discutir problemas ambientais que possam ser considerados comprometedores da qualidade de vida urbana; realizar um estudo e uma avaliação especifica da intensidade e da existência do ruido, como um fator poluente $e$ comprometedor da qualidade de vida no meio urbano por medição técnica; avaliar o ruido como um problema real no meio urbano e a sua percepção como tal pela população em estudo; avaliar os impactos do ruido de tráfego na saúde da população.

Diante da discussão acima proposta, foram formuladas as hipóteses, que poderiam vir a ser analisadas no transcorrer deste estudo.

1- H1: O ruido do tráfego existe como um problema ambiental nas áreas residenciais urbanas na cidade de Brasilia;

2- $-\mathrm{H}$ 2: O ruido é um problema ambiental nas áreas residenciais da cidade de Brasilia e é percebido pela população que prioriza a sua solução;

3-H 3: $\quad$ O ruido è um problema ambiental nas áreas residenciais urbanas na cidade de Brasilia e gera efeitos negativos na saúde da população;

4- H 4: As reaçōes de incômodo ao ruido estão relacionadas ao perfil do individuo e às suas preferências quanto à área onde reside.

\section{2 - Etapas do Estudo}

Considerando não apenas os objetivos a serem alcançados neste estudo, como também as hipóteses a serem analisadas, buscou-se elaborar 
uma metodologia adequada para o desenvolvimento da pesquisa, subdividindo-a em três etapas: revisão bibliográfica sobre o tema; realização de um estudo de caso, por meio de uma pesquisa aplicada em uma zona residencial na cidade de Brasilia; por último, discussão e análise estatística dos resultados.

\subsection{1 - Revisão Bibliográfica}

A revisão bibliográfica constituiu-se na busca de uma base teórica que possibilitasse um enriquecimento do conhecimento cientifico do problema, tanto para situá-lo na realidade ambiental urbana atual, como também para sustentar as discussões apresentadas na conclusão.

Foi efetuada uma pesquisa de publicações nacionais e internacionais nesta área com vistas à obtenção de: caracterização e discussão conceitual de termos considerados na avaliação ambiental de cidades brasileiras, tais como: meio ambiente urbano, qualidade de vida urbana e indicadores ambientais; aprofundamento do conhecimento cientifico sobre o tema ruido, abordando suas fontes, sua intensidade e sua propagação no meio urbano, bem como seus impactos à saúde humana; conhecimento de metodologias e modelos da psicologia ambiental, na avaliação perceptiva do homem e do meio ambiente; seleção do método estatístico para a análise da significância dos resultados obtidos na pesquisa do estudo de caso.

\subsection{2 - Desenvolvimento do Estudo de Caso}

\section{a) Seleção da Área}

A segunda etapa consistiu no desenvolvimento do estudo de caso. Primeiramente selecionou-se a área de estudo, tendo como critérios : ser uma cidade planejada; ser uma zona residencial multifamiliar, próxima a uma via, que atuasse como fonte de ruido; ser preferencialmente uma situação urbana, repetitiva e de presença comum na cidade, para obter-se 
uma avaliação mais abrangente e referencial do ruido de tráfego urbano como poluição na cidade.

Diante dessas premissas, foi selecionada a cidade de Brasilia, visto que é uma cidade que possui um planejamento urbano rigido. Foi, então, escolhido o Eixo RW, que compreende uma das vias de ligação entre os dois extremos sul e norte da cidade, onde circula a maior parte dos automóveis e é, simultaneamente, um corredor do transporte coletivo. Esta via situa-se ao longo de todo o sentido transversal da cidade, indo do inicio da Asa Norte até o final da Asa Sul, e apresenta ao longo de toda sua extensão uma zona residencial multifamiliar (Anexo 1).

Como o trecho acima definido seria muito extenso para ser adotado integralmente, foi necessária, nesta etapa, a adoção de novos critérios para o dimensionamento físico da área de estudo. Buscou-se, por meio de uma análise do volume e do comportamento do tráfego ao longo do dia, a definiçāo do trecho da via mais adequado para o desenvolvimento do presente trabalho. Considerando-se a área central como o principal ponto de atração da cidade e que as vias de acesso a ela apresentam maior volume de tráfego e, consequentemente, maior emissão de ruído, foram selecionadas dez quadras residenciais vizinhas a estas vias : cinco quadras na Asa Sul (SQS 104 , SQS 105 , SQS 106, SQS 107 e SQS 108) e cinco quadras na Asa Norte (SQN 104, SQN 105, SQN 106, SQN 107 e SQN 108) (Anexo 1).

Posteriormente, a área foi analisada empiricamente, buscando obter-se o perfil arquitetônico das edificações residenciais, dimensão de afastamentos da via, tipos de vegetação presentes entre a via e as edificações e, por último, a seleção dos blocos que comporiam a amostra.

Os blocos selecionados compreenderam aqueles situados paralelos e lindeiros à via selecionada, pertencentes às quadras $104,105,106,107$ e 108 da Asa Sul e às quadras de mesmo número situadas na Asa Norte (Figura 1). 
Figura 1 - Posição das quadras em relação ao Eixo Rodoviário Oeste (ERW) 


\section{b) Definição do Instrumento de Coleta de Dados}

Como instrumento de maior importância na efetividade da pesquisa, selecionou-se o questionário. Após a definição da área de estudo, foi iniciada a elaboração do questionário a ser aplicado.

Algumas criticas têm sido feitas à utilização de questionários na realização de pesquisas junto à população. Questiona-se a representatividade das amostras para seu universo real, e também a possivel subjetividade dos resultados obtidos.

Considerando ser imprescindivel a utilização do questionário como procedimento na metodologia deste estudo, buscou-se, por meio de consultas à área da psicologia ambiental, uma referência científica para a seleção da amostra, a elaboração de questionários e a aplicação dos mesmos. Tentou-se desta forma, minimizar subjetividade e otimizar os resultados almejados na pesquisa.

Devido à complexidade do assunto a ser abordado no questionário, por se tratar de reações perceptivas e comportamentais frente a questões ambientais, houve a preocupação de, primeiramente, definirem-se as metas.

As metas a serem alcançadas com a aplicação do questionário ficaram assim definidas :

a) conhecimento do nivel de percepção e da opinião sobre a qualidade ambiental urbana oferecida na cidade de Brasilia e, especificamente, na área residencial em questão;

b) os niveis de percepção, de avaliação e de prioridade dados ao ruido do tráfego urbano como problema ambiental.

c) identificação de efeitos diretos e indiretos que possam ser causados pelo ruido à saúde humana;

d) obtenção de variáveis pessoais e locais especificas da amostra selecionada, que propiciem a avaliação de qualquer interferência das mesmas nos resultados.

Iniciou-se, posteriormente, o rascunho das questões e sua organização buscando uma seqüência lógica e de fácil entendimento para a 
população à qual seria aplicado o questionário. Segundo Marans (1987), o questionário deve apresentar uma forma em que as idéias sejam comunicadas de uma forma clara, interessante e objetiva.

Neste momento, encontrou-se um tópico, considerado sempre polêmico na elaboração dos questionários - o tipo de pergunta a ser formulada: se aberta (respondida nas palavras da própria pessoa) ou fechada (respondida a partir de alternativas oferecidas pelo pesquisador).

Segundo Solorzáno (1991), a opção pelo uso de um dos tipos ou até mesmo a junção dos dois em um mesmo questionário dependerá, principalmente, dos dados a serem coletados e do método de coleta a ser utilizado na pesquisa.

Outra discussão foi a forma de aplicação do questionário - se através do correio, de entrevista por telefone ou de entrevista pessoal com a amostra. Segundo Marans ( 1987), a seleção de um método particular de coleta de dados depende de vários fatores, tais como: tipo de questões que - pesquisador deseja perguntar; número e distribuição espacial da população na qual serão aplicadas as questões; os custos de orçamento alocados para a coleta.

São geralmente utilizadas três técnicas para coletar dados em pesquisas: entrevista pessoal, entrevista por telefone e questionário enviado pelo correio, apresentando cada uma delas suas respectivas vantagens e desvantagens (Gouveia, 1991)

Apenas quando ocorre a definição do método e se tem a idéia do que será perguntado, o pesquisador pode iniciar o processo de elaboração das questões.

Diante dessa discussão, optou-se pela aplicação dos questionários via entrevistas diretas no local com datas pré-marcadas, por telefone e, como última opção, pela entrega direta do questionário às pessoas, fornecendo uma explicação prévia do assunto e telefone de contato para dúvidas e determinação da data de retorno. Optou-se, também, pelo desdobramento máximo do conteúdo a ser abordado no questionário, em questōes curtas, objetivas e fechadas. 


\section{c) O Questionário}

A primeira versão do questionário continha 39 questões, sendo duas delas abertas e as demais fechadas. Buscou-se, na elaboração das perguntas, atingir o atendimento pleno das metas definidas, utilizando-se uma linguagem clara para favorecer uma maior compreensão das questões pelos entrevistados e o ordenamento das mesmas por assuntos e escala de análise.

Apesar de todo o cuidado na elaboração dos questionários, questões ainda foram levantadas sobre a necessidade da realização de um pré-teste para sua avaliação (cópia do questionário no Anexo 2).

Segundo Marans (1987), questionário que apresenta uma sequência lógica e cuidadosa para o pesquisador pode parecer de dificil compreensāo para a população a ser estudada. Torna-se, então, necessária a realizaçāo dos pré-testes para detectar a efetividade do questionário e das questões elaboradas especificamente para atingir os objetivos propostos

Assim, optou-se pela aplicação do pré-teste, na área de estudo, para analisar a sua eficiência como meio de obtenção de dados. Considerando ainda que, para o cálculo final do tamanho da amostra, seria necessário ter-se um valor previsto de prevalência de seu comportamento frente à questão básica do questionário, foi realizada, juntamente com o pré-teste da pesquisa, esta avaliação. Isto possibilitou a obtenção dos indices necessários ao dimensionamento adequado da amostra. A questāo, considerada como básica no questionário, foi aquela que se referia à identificação do incômodo causado pelo ruido.

O pré-teste consistiu na aplicação do questionário a 50 pessoas buscando-se observar a capacidade de resposta às questões elaboradas, o conteúdo das mesmas, bem como o tempo necessário para a execução de todo o questionário. Posteriormente foram feitas as correções, buscando, no produto final do questionário, sua perfeita adequação para atender aos objetivos inicialmente traçados. 
As questões de números um (1) a oito (8) foram elaboradas para obter a percepção e a opinião da qualidade ambiental urbana no bairro estendendo-se também à cidade onde reside a população da amostra.

As questões de números nove (9) a vinte (20) abordaram desde o tempo de exposição, a intensidade da percepção do ruido como um problema ambiental urbano até a sensibilidade e o nivel de incômodo causado pelo ruido.

As questões do números vinte e um (21) a trinta e um (31) foram elaboradas para analisar a interferência e os efeitos do ruido no bem-estar e na saúde da população.

As últimas questōes, de números trinta e dois (32) a quarenta um (41), foram elaboradas para obter dados de caracteristicas físicas dos apartamentos, dimensão familiar e informações pessoais da população da amostra, tais como: idade, sexo e nivel escolar. Esses dados foram utilizados para avaliar a existência de qualquer relação entre os resultados obtidos e essas variáveis.

$\mathrm{Na}$ elaboração das questões, buscou-se utilizar uma linguagem simples e direta, de forma a facilitar tanto a aplicação, quanto a compreensão e a análise final do questionário.

Não sendo possivel o acesso real a toda população residente na área de estudo, constatou-se a necessidade do dimensionamento numérico adequado da amostra para a aplicação do questionário, buscando assegurar uma validade estatistica dos seus resultados.

Foram então considerados, paralelamente ao perfil urbano da área de estudo, os seguintes critérios básicos para o dimensionamento final da amostra a ser consultada: o grau de homogeneidade da população; a significância da população amostral utilizada; o número de subgrupos a serem estudados; o grau de confiança dos resultados atingidos; o tempo disponivel para a realização da pesquisa; os recursos financeiros disponiveis.

Esses fatores foram considerados conjuntamente na tomada de decisão do dimensionamento e da caracterização da população 
amostral. Optou-se, assim, pela definição de uma amostra em que a população selecionada fosse integralmente adulta $e$ inserida economicamente na classe de renda de nível médio.

Para definir o número mínimo de questionários a serem aplicados, de forma a garantir a representatividade da amostragem nas oito quadras selecionadas, utilizou-se a seguinte fórmula:

$$
n=\frac{p . q}{d^{2} / z^{2}}
$$

Onde:

$$
\begin{aligned}
& n=\text { tamanho da amostra. } \\
& p=\% \text { de pessoas que afirmaram serem incomodadas pelo ruído. } \\
& q=\% \text { de pessoas que afirmaram não serem incomodadas pelo ruído } \\
& z=\text { variância } \\
& d=\text { margem de erro. } \\
& \text { Logo foi adotado: } p=0,69, q=0,31 \quad d=0,069 \quad z=1,96
\end{aligned}
$$

Como exposto anteriormente, juntamente com a aplicação do préteste do questionário, foi feito um levantamento da prevalência de comportamento da população amostral sobre a questão que identificava a presença do incômodo. Considerando os 50 questionários aplicados nesta etapa, obteve-se que $69 \%$ deles responderam sim e $31 \%$ responderam não, identificando, respectivamente, os valores de $p=0,69$ e $q=0,31$. Aplicando-se os valores de $p$ e $q$ na fórmula, obteve-se $n=172$, definindo ser necessária uma amostra mínima de 172 pessoas.

Foram ainda acrescidos mais $25 \%$ do valor definido como margem máxima de rejeição. A dimensão final da amostra ficou estabelecida em 206 pessoas. Todas essas pessoas eram residentes dos dezessete blocos selecionados para a aplicação da pesquisa. As pessoas que comporiam a amostra foram selecionadas por sorteios dos números dos apartamentos dos blocos das dez quadras.

O período selecionado para aplicação dos questionários foi entre os meses de março a maio de 1999, buscando acompanhar o volume de 
tráfego normal da cidade e evitando, portanto, os periodos de férias escolares que geram grande redução do fluxo de veiculos.

\section{d) A Aplicação dos Questionários}

Os questionários, na sua maioria, foram aplicados por entrevistas diretas pelo pesquisador e por estudantes de pós-graduação previamente treinados. Os demais foram por meio de explicação direta ao entrevistado sobre o conteúdo e a forma de preenchimento e definida a data para o retorno do questionário.

Esta foi a etapa mais complicada da pesquisa, pois vários fatores dificultaram o acesso à amostra selecionada Em muitos casos, foi possivel o contato anterior por telefone, para marcar o horário das entrevistas. Com os demais, diante da dificuldade para encontrá-los, o contato foi feito diretamente no bloco onde a pessoa residia. Diante das dificuldades para encontrar as pessoas selecionadas, foram feitas substituições por meio de novos sorteios.

Outro fator que dificultou a realização das entrevistas foi o problema de insegurança na área urbana, hoje comum nas cidades. Houve dificuldades de convencimento de que se tratava de uma pesquisa científica sobre a qualidade ambiental urbana. A maioria das rejeições que ocorreram foram devidas a esses dois fatores e poucas foram aquelas que aconteceram pelo não interesse na pesquisa.

\subsection{3. - Medição do Ruído do Tráfego}

A etapa de medição do ruido do tráfego urbano foi efetuada no mesmo semestre em que foram aplicados os questionários

Foram utilizados dois equipamentos para as medições: um medidor de nivel de pressão sonora, analógico, marca Entelbra - ETB -142A série AM134, cedido pelo Instituto de Ecologia e Meio Ambiente - IEMA - Distrito Federal sendo o outro também um medidor de nivel de pressão sonoradosimetro digital, que fornece a média temporal dos vários niveis de ruído. 
marca Rionco - NL- 04 JISC 1505-1900, IEC 651: 1979 Type 2, IEC 804: 1985 Type 2. A utilização do equipamento análogico seguiu as recomendações preconizadas pela Companhia de Tecnologia de Saneamento Ambiental/SP - CETESB ( Szwarc et al., 1992 ). O tempo minimo de medição, em cada ponto, foi de vinte minutos e, posteriormente, foi realizado o cálculo do nivel de ruído (Leq), utilizando-se a fórmula :

$$
L e q=0,01(L 90-L 10)^{2}+0,50(L 90+L 10)^{2}
$$

Os dois equipamentos estavam devidamente calibrados. As medições foram feitas no periodos de pico de tráfego, ou seja, nos horários previstos para a maior movimentação de veiculos.

Foram definidos quatro pontos de medição. Considerando que a pesquisa tem como área de abrangência tanto a Asa Sul como a Asa Norte, trabalhou-se com dois pontos na Asa Sul e dois na Asa Norte, nas quadras de números 104 a 108. Na localização dos pontos de medição, foram considerados o comportamento diário do tráfego nesta via, seu papel como via coletora, distribuidora e sua grande importância no acesso à zona central da cidade.

Os dados foram coletados nos horários entre $7 \mathrm{~h}$ e $8 \mathrm{~h}$ da manhã e entre $17 \mathrm{~h} 45 \mathrm{~min}$ e $19 \mathrm{~h}$ da noite. Em alguns dos apartamentos, tanto na Asa Sul como na Asa Norte, foram também feitas medições com as janelas abertas para observar a variação do nivel de ruido emitido no ambiente interno em ambas as situações.

$\mathrm{Na}$ área externa, as medições foram feitas próximas às fontes, a 1,30 $m$ da via e no nivel térreo dos blocos. Nos apartamentos, as medições foram feitas no primeiro, segundo e terceiro andares com as janelas fechadas. $E$, hoje, é um hábito comum dos moradores desses prédios manter as janelas fechadas quase que ao longo de todo o dia de modo a minimizar a intensidade do som na área interna de suas residências 
Em seguida, após a finalização da aplicação dos questionários, as respostas foram compiladas e convertidas em valores numéricos, de modo a serem tabuladas e analisadas.

\subsection{4. - Tratamento dos Dados}

Foi primeiramente criado o banco de dados, utilizando-se o programa EPI - INFO, versão 6.0 (WHO, 1994a).

$\mathrm{Na}$ etapa de análise, utilizando-se o mesmo programa, foram obtidas as frequências dos resultados em todas as questões de modo a caracterizar as respostas da amostra. Posterior a essa etapa foram realizados cruzamentos entre as variàveis que identificavam reações e comportamento frente ao ruido e as variáveis sexo e faixa etária de modo a obter uma avaliação da presença de associações entre elas. A etapa posterior da análise constituiu-se na realização de cruzamentos entre as variáveis que identificavam o comportamento da amostra frente ao ruido, de modo a obter a identificação de associações estatisticas entre elas. Utilizou-se como método de avaliação estatístico, um estudo de associações, onde os valor do $\chi^{2}$ e o valor de $\mathbf{p}$ foram considerados para a identificação da significância das associações. Nos cruzamentos onde os valores de $p$ foram inferiores a $0,05(p<0,05)$, as associações foram consideradas significantes, onde se concluiu haver correlação entre os comportamentos

$O$ interesse em investigar a presença de correlações estatisticas múltiplas entre as variáveis levou a realização da última etapa de avaliação ,que consistiu em uma análise estatística de multivariância utilizando-se 0 método da análise canônica através do programa SPSS versão 8

Buscou-se, nesta etapa, a análise integral dos resultados buscando a atender os objetivos desta pesquisa e a comprovação das hipóteses levantadas no inicio do estudo 


\section{4 - CIDADE DE BRASILIA}

"Nasceu do gesto primário de quem assinala um lugar ou dele toma posse: dois eixos cruzando-se em ângulo reto, ou seja, o próprio sinal da cruz"

Lúcio Costa

\section{1 - Introdução}

A cidade de Brasilia, fundada em 1960, caracteriza-se por seu planejamento. O plano urbanístico da cidade incorpora idéias modernistas fundamentais e apresenta um planejamento prévio de uso e ocupação do solo urbano de toda a área prevista, contendo propostas de cunho social.

Um cruzamento axial define a área de desenvolvimento urbano. Os edificios públicos são dispostos ao longo do eixo, direção leste-oeste (Eixo Monumental), enquanto as zonas residenciais sāo dispostas no outro eixo (Eixo Rodoviário), na direção norte-sul. Esses dois vetores da organização urbana atuam, ao mesmo tempo, como vias expressas garantindo acesso aos vários setores da cidade, podendo ser considerados como geradores do plano de Brasilia.

O traçado urbano do Plano Piloto, na concepção original do plano urbanistico da cidade, consistia em avenidas largas, sem cruzamentos e poucos semáforos. Privilegiava o deslocamento através do transporte privado, caracteristica esta até hoje mantida.

O urbanismo modernista homogeneiza a heterogeneidade dos usos e cria setores exclusivos para cada função urbana. O plano de Brasilia segue essa identidade, prevendo uma setorização plena do uso e da ocupação do solo para toda área da cidade, conforme mostra o Anexo 1. Tem-se a distribuição de setores destinados a atividades especificas, tais como politico-administrativas, residencial, comercial, de serviços terciários, de lazer e para as demais atividades que compõem a vida urbana da população. 
O Eixo Monumental, onde está disposto o setor politico administrativo, divide o Eixo Rodoviário residencial nas Asas Sul e Norte. Cada asa dividese em nove faixas, numeradas de 100 a 900 . O número da faixa indica sua posição, a leste (par) ou a oeste (ímpar) da via expressa. As faixas de 100 a 400, duas de cada lado do Eixo Rodoviário, norte sul, possuem superquadras residenciais e comerciais. Ao número 500 corresponde uma faixa comercial, a Via W3, onde também se encontram instalações e serviços. As faixas 600 e 900 contém equipamentos comunitários de maior dimensão, como escolas, que servem a diversos setores e, também, equipamentos públicos. $\mathrm{Na}$ faixa 700 , tem-se a disposição de residências unifamiliares geminadas em toda a extensão da direção norte-sul .

Cada faixa, nas séries de 100 a 400 , tem quinze superquadras, totalizando sessenta em cada asa e 120 na cidade inteira; são identificadas numericamente, iniciando a numeração, de cada lado, a partir do cruzamento dos eixos.

A área central de Brasília desenvolve-se simetricamente, ao longo do Eixo Monumental, nos sentidos norte $\rightarrow$ sul da cidade e ao longo do Eixo Rodoviário, nos sentidos leste $\rightarrow$ oeste. Compreende os setores destinados à realização de atividades administrativas, comerciais, de serviços e de diversões, manifestando, de forma bastante evidente, as caracteristicas próprias do centro das cidades, constituindo-se em um setor importante dentro do contexto urbano. Grande parte do tráfego urbano converge para esta área por sua especificidade quanto à concentração da oferta de serviços. Localizada no seu ponto mais central está a Estação Rodoviária de Brasilia, importante ponto de convergencia das linhas de ônibus que efetuam não apenas as ligações com as regiões do entorno mas também os serviços internos da cidade. É, portanto, um dos pólos de maior fluxo de ônibus e veiculos, responsável por um número significativo de viagens.

$A$ idéia original de integrar, nas quadras residenciais, as diferentes classes sociais não foi possivel em virtude de sua alta valorização imobiliária. A população de baixa renda foi obrigada a deslocar-se para o 
entorno de Brasilia, onde se localizam as "cidades satélites" distantes, aproximadamente, de 25 a $50 \mathrm{~km}$ do centro administrativo de Brasília.

Assim, diariamente, identifica-se um deslocamento pendular entre as "cidades satélites" e o hoje denominado "Plano Piloto".

Atualmente, a cidade de Brasilia, apresenta o índice de motorização do pais de $38 \%{ }^{1}$ sendo o maior do pais, podendo ser justificado tanto pelas necessidades criadas pelo próprio plano urbanístico como também pela alta renda média característica da população cidade.

Ela destaca-se ainda pela sua paisagem urbana com grande predominância de áreas verdes. É hoje uma das cidades que apresenta o maior indice de área verde por habitante. Tem, atualmente, uma população de 262264 habitantes. Considerando a população distribuida pela regiões administrativas, ou melhor, cidades satélites, o Distrito Federal tem uma população de 1887016 . Portanto a previsão de uma população total de 500000 habitantes já foi bastante ultrapassada apresentando, atualmente, uma realidade bem diferente que já obriga uma adequação do plano urbanístico ao desenvolvimento da cidade.

Brasilia é uma cidade nova - 40 anos - que, diante de sua proposta urbana, gera expetativas positivas quanto à sua qualidade ambiental. Entretanto são muito escassos os estudos sobre seu aspecto ambiental atual, tornando-se necessária uma avaliação da relação entre as vertentes de sua proposta urbana modernista e os beneficios para a qualidade de vida de sua população.

Hoje ela é uma cidade tombada, pela UNESCO, como patrimônio histórico da humanidade representando os ideais $e$ as vertentes do urbanismo modernista

\section{2 - Área de Estudo}

Considerando o interesse desta pesquisa em obter uma avaliação da qualidade ambiental da cidade, quanto à poluição sonora, foram definidos

\footnotetext{
${ }^{1}$ Fonte-Ministério da Justiça - Departamento Nacional de Transito-- DENATRAN (1999)
} 
critérios para identificar uma área de estudo adequada. Um fator de grande importância é a caracterização do fluxo do trảfego.

Conferiu-se ao eixo central, correspondente às três vias paralelas de acesso, a função circulatória-tronco para o tráfego local e, dispondo-se ao longo desse eixo, o grosso dos setores residenciais. $O$ eixo central constitui - Eixo Rodoviário e os eixos paralelos constituem o Eixo RW (eixo rodoviário W-Oeste) e o Eixo RL (eixo rodoviário L-Leste) situados, respectivamente, a oeste e leste do eixo central que é a via de maior porte entre eles.

Essas vias têm como origem e destino as áreas internas da cidade e, também, as cidades satélites e as áreas rurais situadas no entorno de Brasilia. Todos as vias têm um papel importante na movimentação de ida e vinda da população. O tráfego compõe-se de veiculos de passeio, de carga e de uma grande circulação de ônibus para atender à demanda de transporte coletivo.

Nenhuma das vias possui qualquer semáforo, tendo sido previsto para elas um fluxo continuo e livre, ao longo de todo sentido longitudinal da cidade. Foi prevista, ainda, juntamente com essa proposta, a oferta de travessia transversal subterrânea para pedestres, de modo a não haver necessidade de interrupção do tráfego. As três vias citadas são separadas por áreas verdes e não há nesses espaços qualquer tipo de ocupação.

Buscou-se, na definição da área de estudo, selecionar aquelas quadras mais próximas da área central por ser o trecho, ao longo de todo o eixo, onde há uma concentração maior de volume do tráfego e que, consequentemente, apresenta o maior potencial para emissão de ruido.

A área selecionada compreende uma zona residencial multifamiliar, situada nas quadras de números cem (Anexo 1), disposta ao longo da via denominada Eixo Rodoviário W, que se caracteriza por apresentar duas pistas, em sentidos opostos, sendo que cada uma delas possui duas faixas de rolamento com $3,5 \mathrm{~m}$ de largura conforme mostra as Figuras 2,3 e 4 referente à aqueles situados na Asa Sul e as Figuras 5, 6 e 7 que mostram a disposição dos prédios nas quadras da Asa Norte. Compõe, juntamente com - Eixo Rodoviário e o Eixo Rodoviário L, as vias principais de ligação da 
Figura 2 - Identificação dos blocos e pontos de medição de ruído considerados na pesquisa - Super-Quadras 104 e 105 Sul

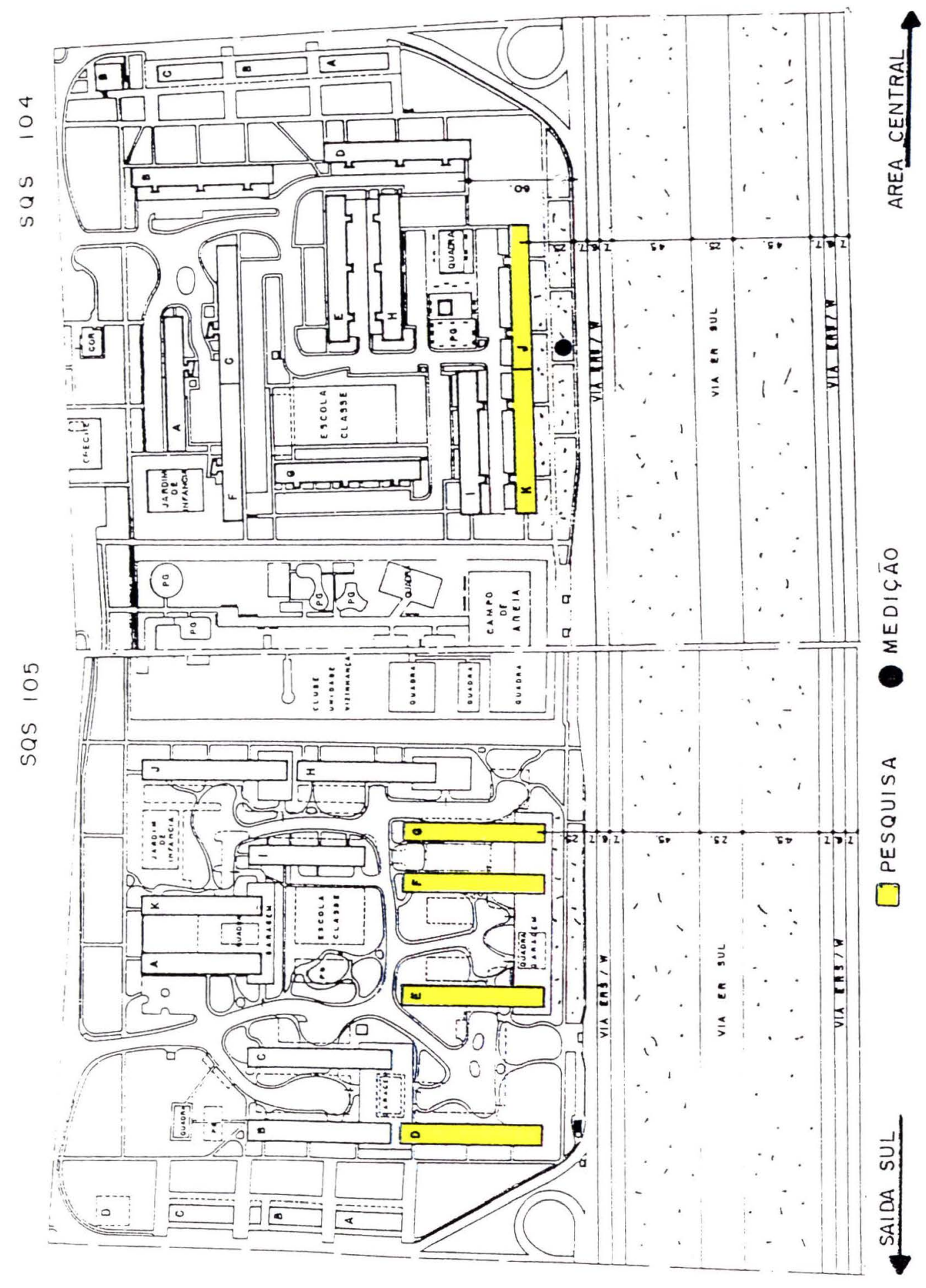


Figura 3 - Identificação dos blocos e pontos de medição de ruído considerados na pesquisa - Super-Quadras 106 e 107 Sul

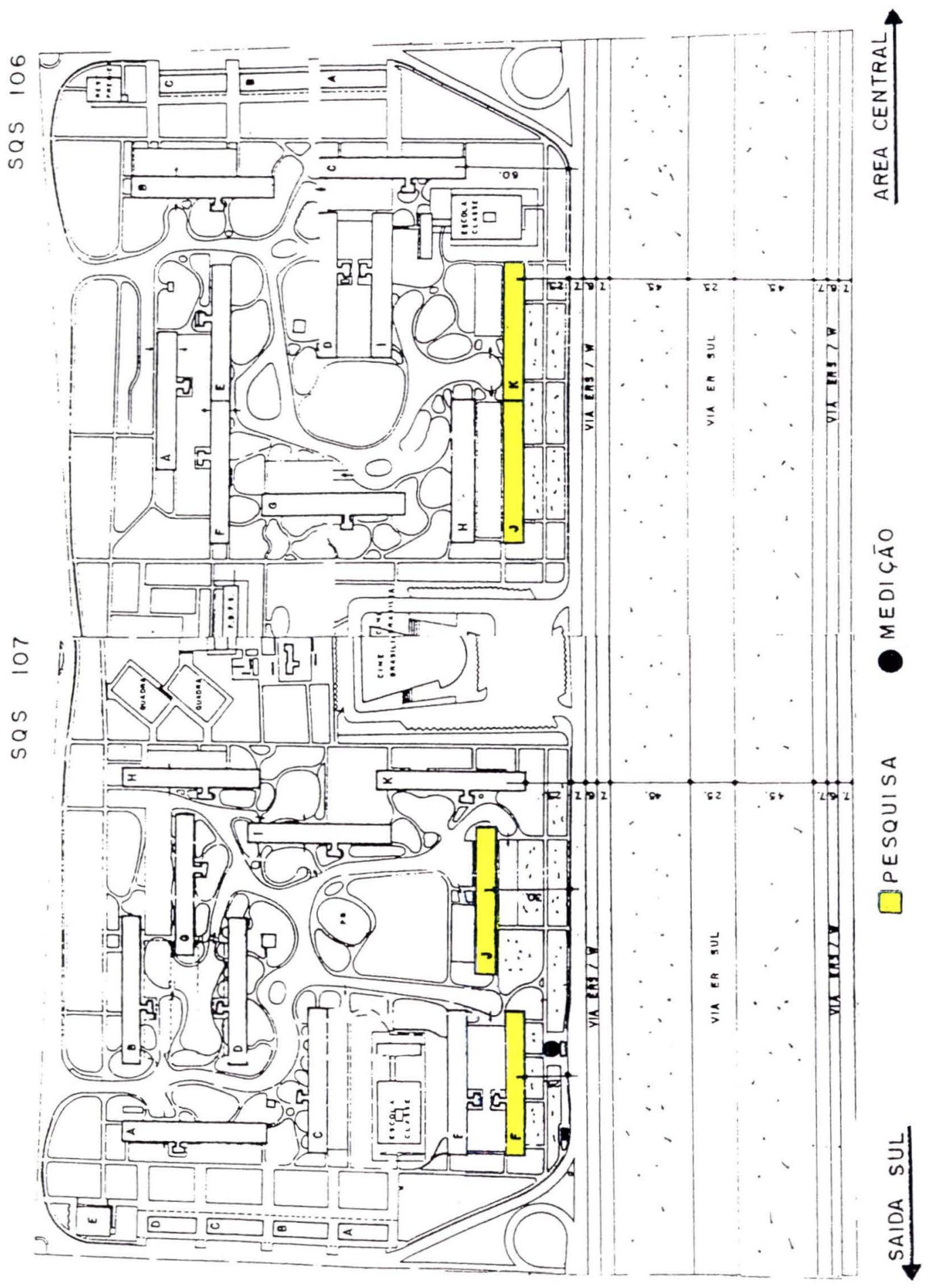


Figura 4 - Identificação dos blocos e pontos de medição de ruído considerados na pesquisa - Super-Quadra 108 Sul

\lrcorner
$\mathbb{a}$
$\mathbb{E}$
$z$
$u$
$u$
$\varangle$
$w$
$\sigma$
$\alpha$

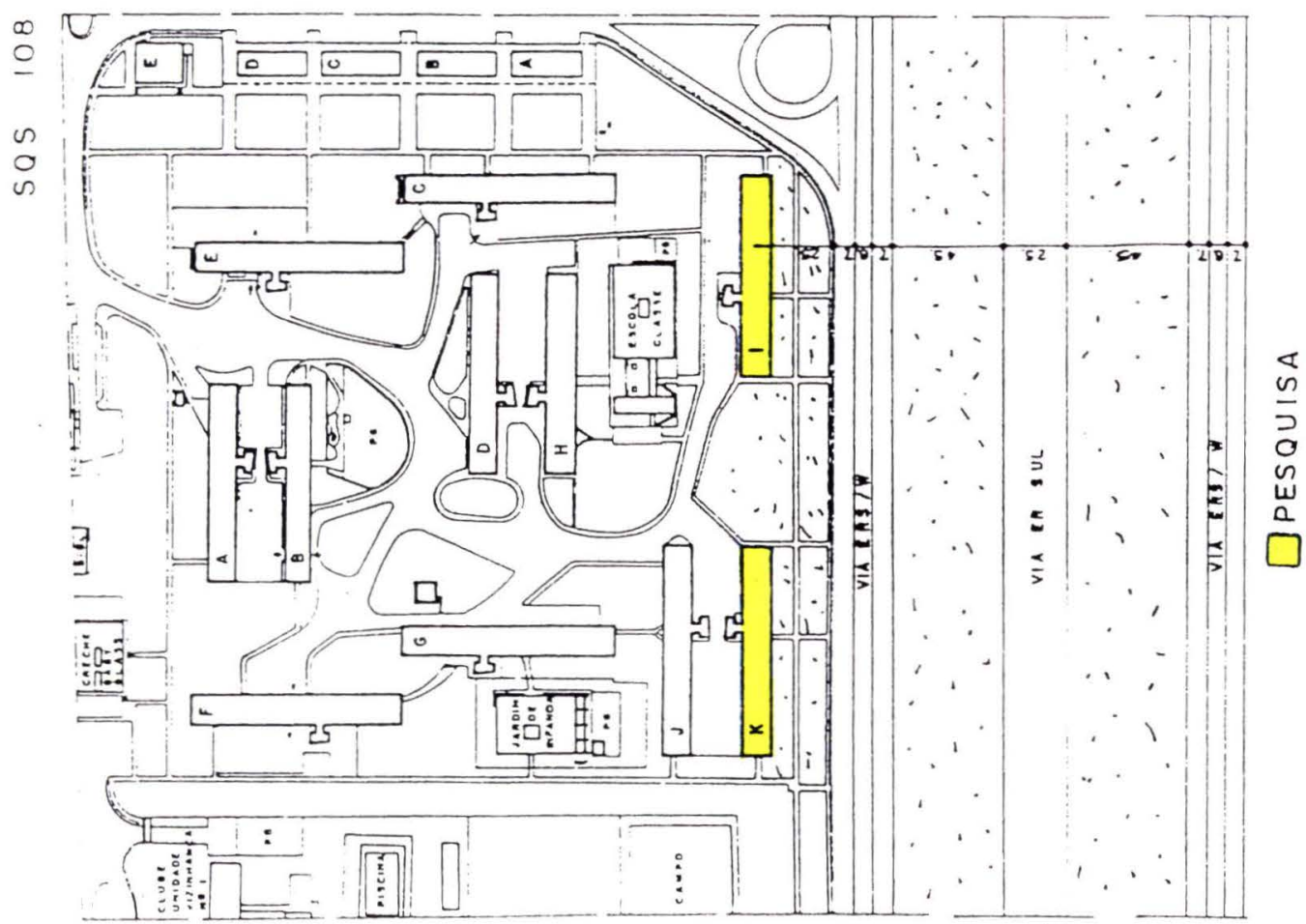

5
5
$\frac{5}{4}$
5 
Figura 5 - Identificação dos blocos e pontos de medição de ruído considerados na pesquisa - Super-Quadras 104 e 105 Norte

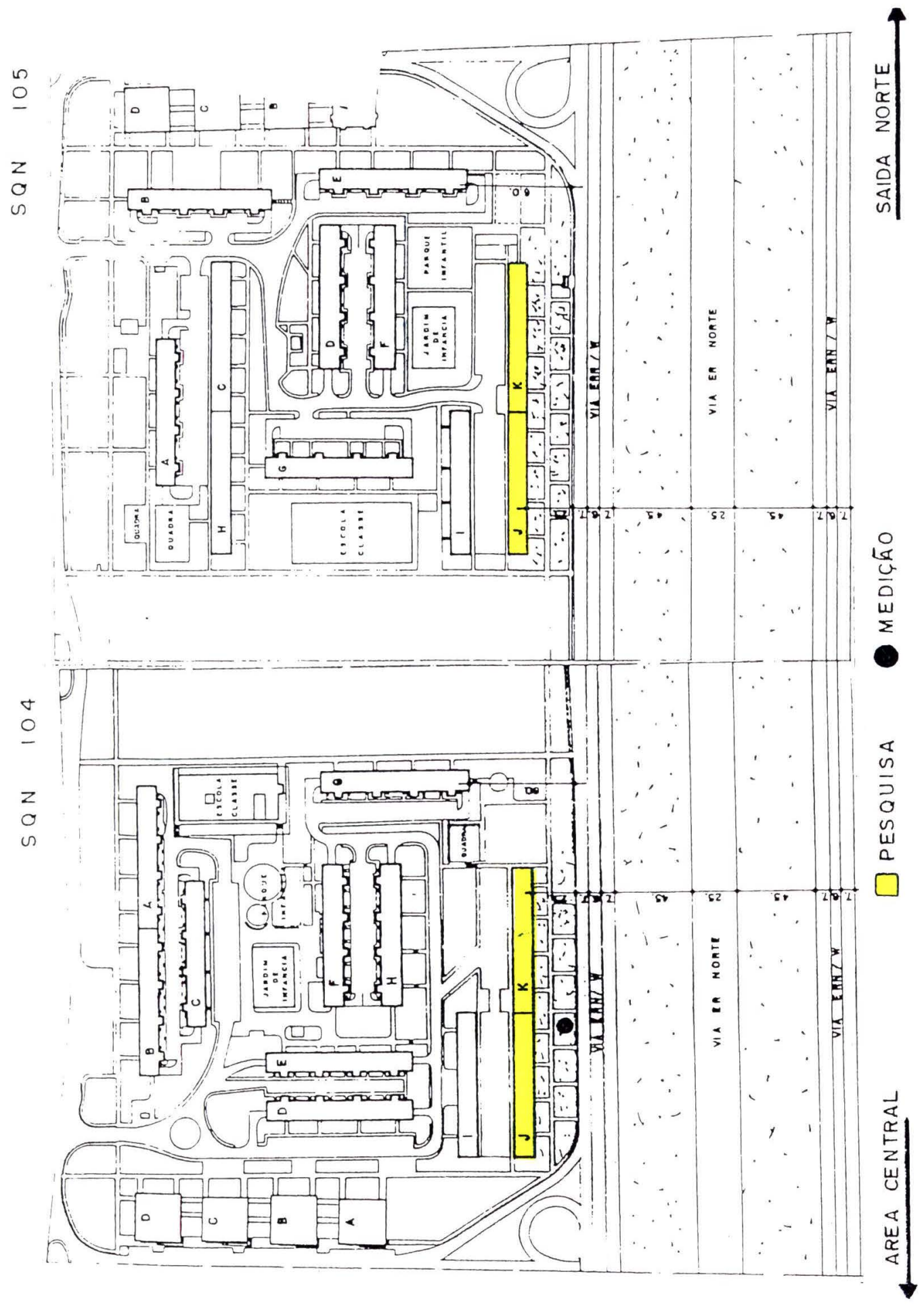


Figura 6 - Identificação dos blocos e pontos de medição de ruido considerados na pesquisa - Super-Quadras 106 e 107 Norte
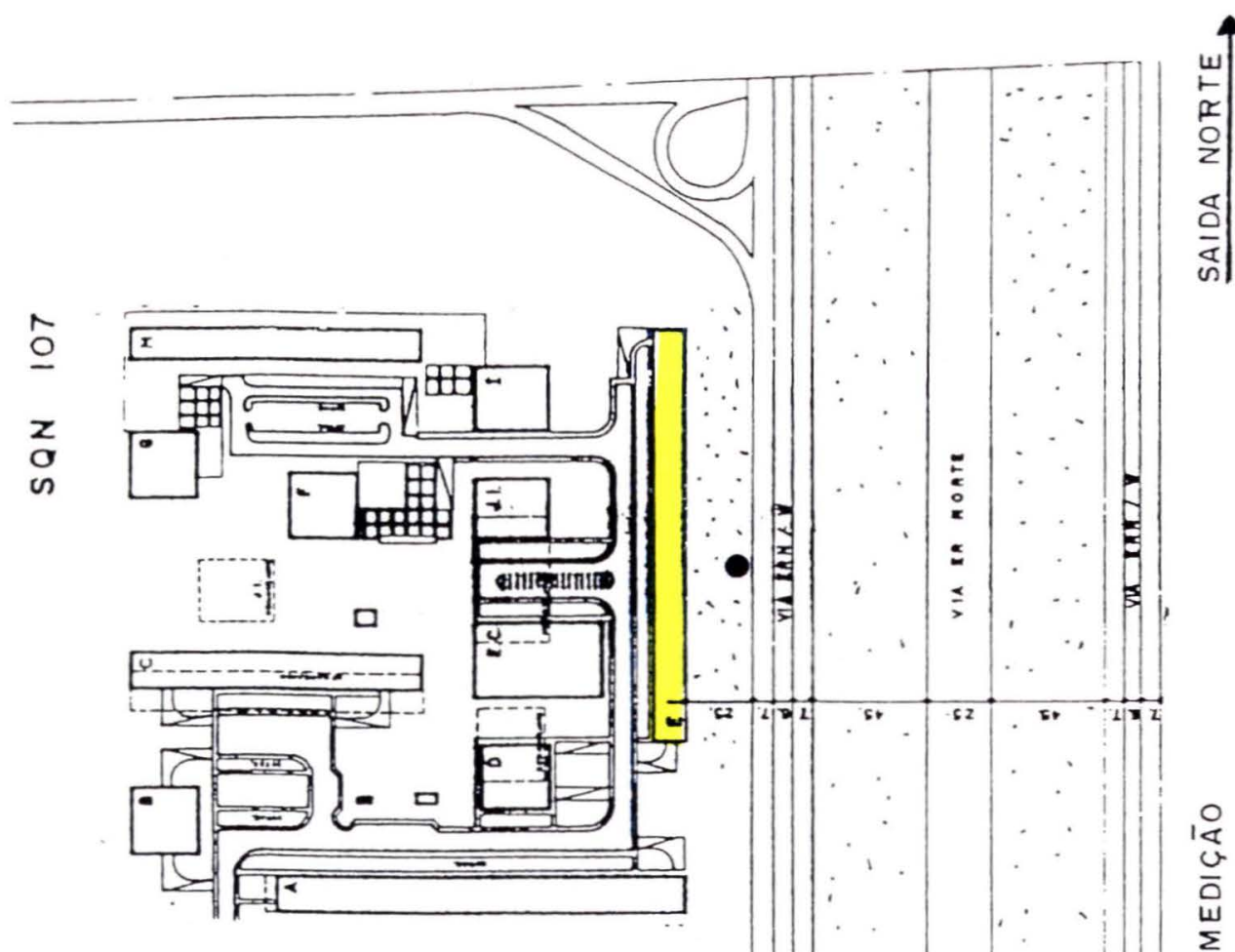

这

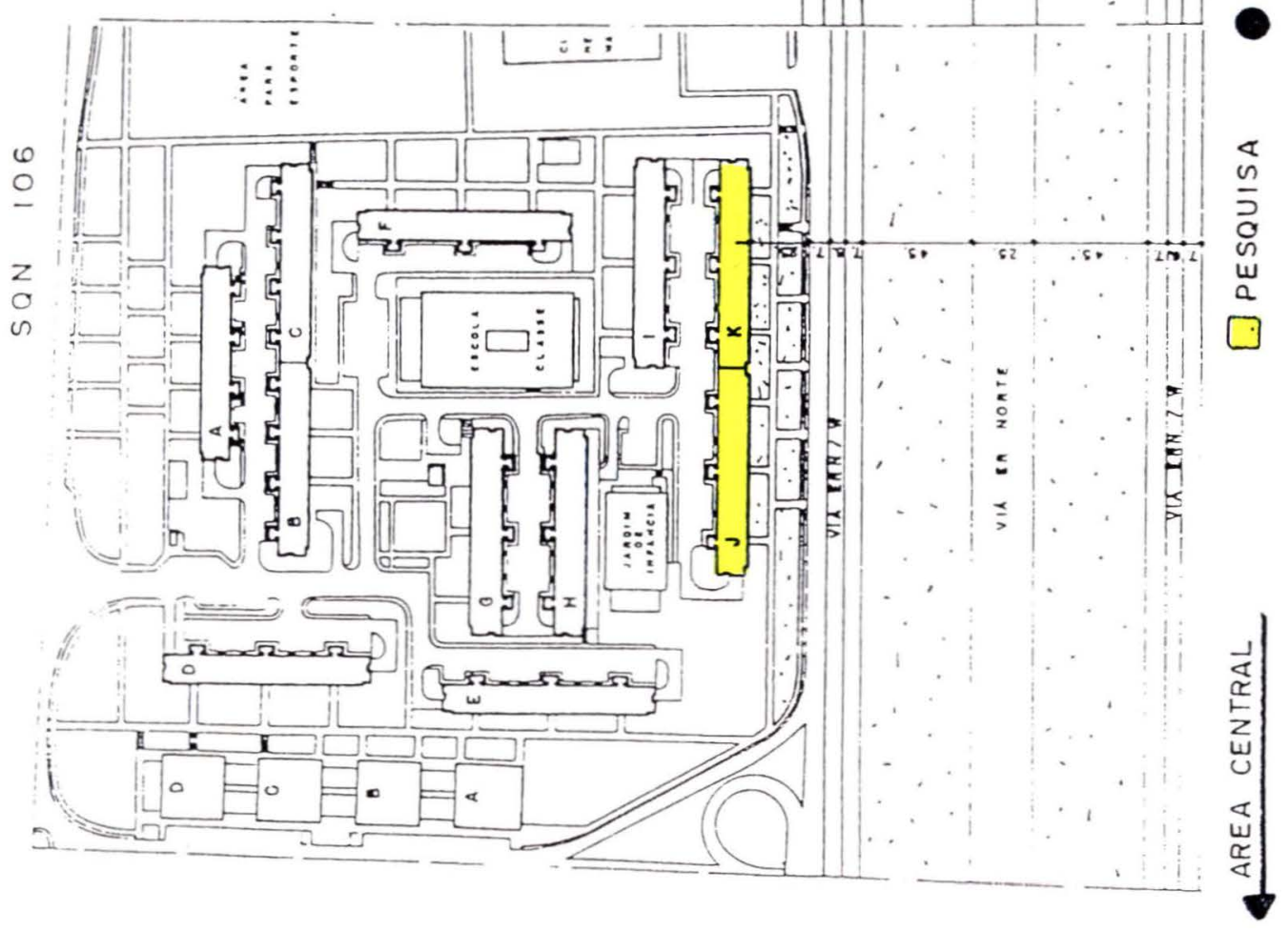


Figura 7 - Identificação dos blocos e pontos de medição de ruído considerados na pesquisa - Super-Quadras 108 Norte

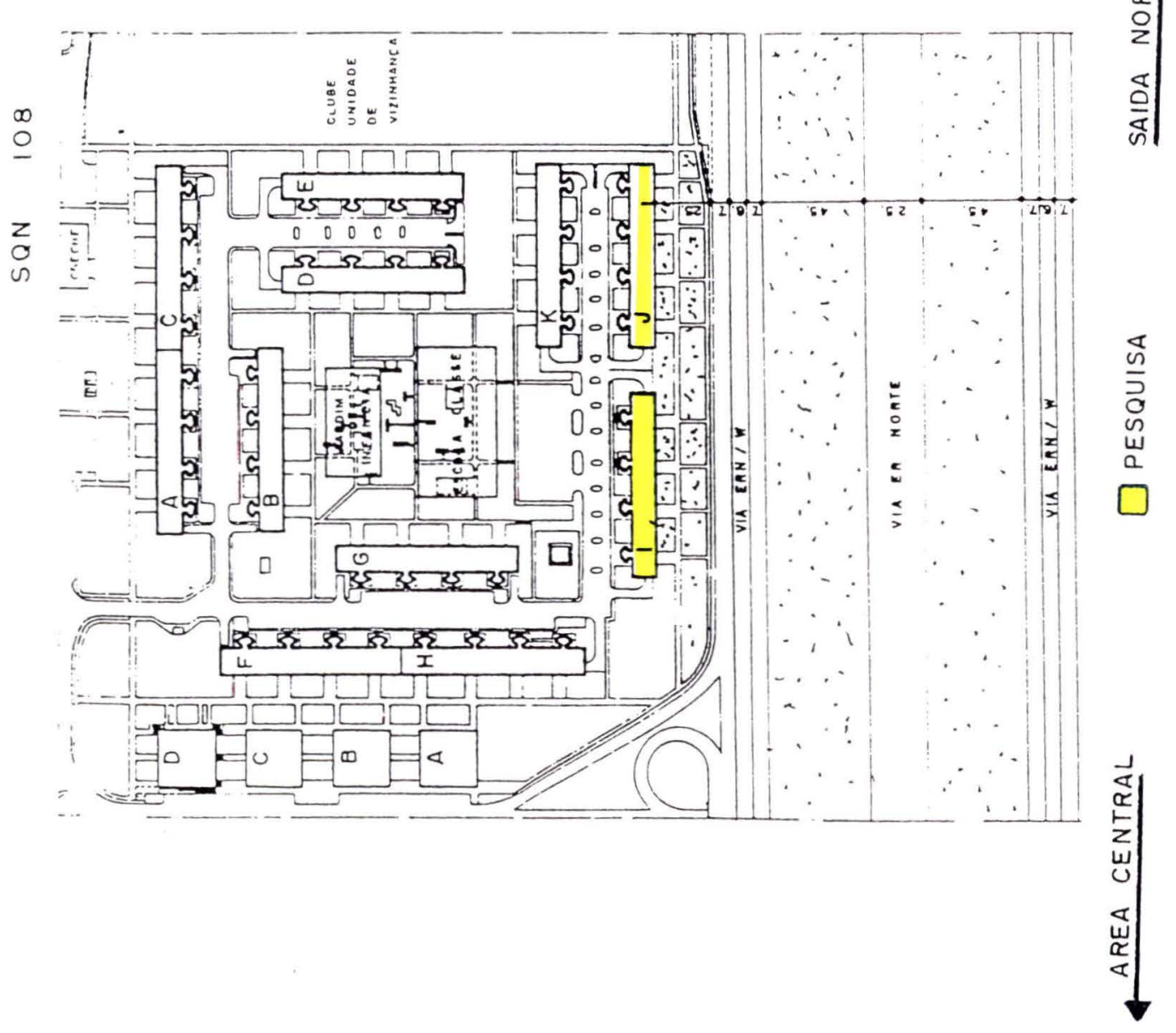


Asa Norte à Asa Sul e, consequentemente, o acesso principal à área central de Brasilia. No Eixo RW, em sua lateral oeste, tem-se o uso residencial ao longo de toda sua extensão. A área residencial é subdividida em quadras, com a oferta de residências multifamiliares, com gabaritos de seis andares. A numeração dessas quadras inicia-se na área próxima ao centro com a Superquadra 102 indo até a extremidade final do eixo, com a Superquadra 116. A Asa Norte e a Asa Sul obedecem ao mesmo sistema de endereçamento, havendo apenas a diferenciação do sentido. Portanto em cada Asa tem-se a oferta de 15 quadras para uso exclusivo de residências, com gabarito de seis andares. A cada duas quadras, no sentido perpendicular ao eixo, há uma via que atende tanto o acesso ao comércio local como também ao interno das quadras e os eixos laterais atuam como vias distribuidoras e coletoras das vias locais. Embora o Eixo rodoviário L apresente, também, uma área de uso residencial ao longo de toda a sua extensão, o motivo da escolha do Eixo $W$ deveu-se ao fato de que ele apresenta um volume superior de tráfego conforme mostra a Tabela 1 e, consequentemente, constitui uma fonte com maior potencial para análise do ruido do tráfego urbano e de sua interferência na qualidade de vida das pessoas residentes em áreas próximas.

Tabela 1 - Volume de tráfego das vias existentes frente a zonas residenciais multifamiliares na cidade de Brasilia

\begin{tabular}{lrrr}
\hline & Sentido sul/norte & Sentido norte/sul & Volume de tráfego/dia \\
\hline Eixo Oeste(W) Norte & 7500 & 23000 & 30500 \\
Eixo Leste(L) Norte & 16500 & 3300 & 19800 \\
Subtotal & 24000 & 26300 & 50300 \\
Eixo Oeste(W) Sul & 9000 & 30000 & 39000 \\
Eixo leste (l) Sul & 30000 & 12500 & 42500 \\
Subtotal & 39000 & 42500 & 81500 \\
L2 Norte & 12000 & 8000 & 20000 \\
L2 Sul & 13000 & 12000 & 25000 \\
Subtotal & 25000 & 20000 & 45000 \\
\hline
\end{tabular}

Fonte: Departamento de Trânsito do Distrito Federal - 2000/DETRAN 
As quadras selecionadas (Anexo 1) estão mais próximas ao Eixo RW entretanto tem-se também como fonte de emissão de ruido o tráfego de veiculos dos dois eixos paralelos, o Central e o Eixo L. Entre esses três eixos existem apenas faixas, com $45,00 \mathrm{~m}$ de largura, destinadas às áreas verdes que os acompanham ao longo de toda a sua extensão dentro da cidade.

Os prédios, onde foi aplicada a pesquisa, encontram-se lindeiros e paralelos aos eixos e todos, com soluções arquitetônicas similares, têm sua fachada principal voltada para eles. Obedecem a uma faixa do afastamento da via de 25,00m, onde foram desenvolvidos jardins, arborização e circulação de pedestres ( Figuras 2,3,4,5,6,7).

A ventilação e a iluminação dos prédios são feitas por esquadrias metálicas e panos de vidro. Nas fachadas, em todos eles, não há qualquer tratamento de isolamento acústico ou térmico.

Considerando as especificidades do plano urbanístico da cidade, a uniformidade do uso e ocupação do solo e as soluções de arquitetura nos prédios de uso residencial; a área selecionada constituiu-se de apenas um trecho urbano, mas característico de uma mesma situação que se estende por toda a cidade. Com isso prevê-se que a conclusão deste estudo possa ser estendida, ou pelo menos adotada, como referência de análise ambiental urbana às áreas externas aos seus limites. 


\section{5 - O RUÍDO URBANO}

\section{1 - Introdução}

O ruido diferencia-se dos demais elementos poluentes urbanos por constituir-se como tal apenas no periodo em que é emitido deixando de existir no momento em que termina a emissão, não restando qualquer vestigio de sua presença que possa permitir uma análise. Inexistindo barreiras, ele não tem limites espaciais, não tem cor, forma ou odor (Beristain, 1998).

Entre os conceitos existentes para o ruido têm-se: "um conjunto de sons sem harmonia", "um conjunto confuso de sons", "qualquer sensação auditiva desagradável ou que incomoda"; assim, esses conceitos sempre denotam o sentido de um som indesejável, que perturba o homem em qualquer uma de suas atividades.

Segundo Beristain (1998) o ruido pode ser definido sob vários aspectos: o subjetivo, o da comunicaçāo, o do prazer e também sob o aspecto da legislação. Sob o aspecto subjetivo, o mais complexo, conceitua-se ruido como qualquer som que seja desagradável. Essa conceituação, entretanto envolve aspectos culturais e preferências pessoais. Sua avaliação é muito dependente do estado de ânimo e da percepçāo pessoal de cada um que a ele esteja exposto.

Na comunicação, o ruido pode ser definido como o som que não transmite qualquer mensagem. Pode também ser definido como um som agradável ou não, que interfira na comunicaçāo de uma mensagem principal, independente da fonte.

Sob o aspecto do prazer, o ruido é considerado como todo som que não apresenta harmonia

Quanto ao aspecto da legislação, tanto nacional como internacional, considera-se ruido como todos os sons vocais, musicais ou aleatórios que superem os niveis estabelecidos permissiveis para determinadas atividades 
e, de maneira fundamental, para a segurança e para o conforto das pessoas. Portanto os limites não devem ser ultrapassados, de modo a garantir a saúde e a tranquilidade dos trabalhadores e da comunidade em geral, independente do prazer que possa causar a certas pessoas.

Observa-se, assim, que a identificação da presença do ruido será sempre relativa, sendo dependente da sensibilidade e da percepção das pessoas envolvidas, ou do tipo de atividades ou ações desenvolvidas por elas.

Analisando o ruido do tráfego urbano, ele apresenta todas as caracteristicas citadas nos conceitos acima descritos: pode ser considerado um som desagradável, não transmite qualquer mensagem, não apresenta harmonia $e$, muitas vezes, supera os niveis de ruido definidos pela legislação. Sob todos os aspectos abordados, è um tipo de som que pode ser definido como ruido.

Embora o conceito de ruido tenha este caráter subjetivo em sua definição, ele tem suas propriedades físicas como uma emissão de som. O som é o resultado da mudança de pressão, no meio, provocada por vibrações ou turbulências. A amplitude desta alteração de pressão é definida como nivel sonoro, e a rapidez com que ela acontece é denominada frequência do som. O nivel sonoro é medido na unidade de decibel (dB) enquanto que a frequência do som é definida em ciclos por segundo ou Hertz. O limiar inferior da audibilidade, pela própria definição, é de zero decibel, sendo, também, dependente da frequência do som emitido, que é perceptível ao ouvido humano quando encontra-se entre o intervalo de frequência entre 20 a 20000 Hertz.

A medida do som em decibel é obtida em uma escala logaritma e não linear: um pequeno aumento na escala de decibel implica em um grande aumento da energia sonora. Tecnicamente, um aumento de três $d B$ representa uma duplicação da energia sonora, e um aumento de $10 \mathrm{~dB}$ representa um aumento de dez vezes mais a intensidade do som no ambiente (Sutter, 1991). 
Adota-se como referência, nas medições de nível sonoro, considerando as limitações da capacidade auditiva humana quanto a intensidade sonora $e$ as frequências entre as três escalas existentes, a escala " $A$ " que é representada pela unidade dB(A). Essa escala pondera os valores dos níveis de ruído para aproximar a resposta em frequência do ouvido humano. Portanto a legislação e medições que são destinadas a avaliar o impacto no ser humano são geralmente realizadas utilizando-se esta ponderação ( Szwarc et al., 1992 ).

O estado normal, quanto à sensibilidade da audição, é considerado como a habilidade de detectar sons que estejam no intervalo de freqüência entre 20 e $20000 \mathrm{~Hz}$. Tem-se como norma a ocorrência de uma redução da capacidade auditiva em pessoas mais idosas (Berglund, 1995).

Considerando a diversidade de abordagens sobre o tema ruido, optou-se, neste capitulo, pela apresentação e discussão em tópicos dos diferentes aspectos que o envolvem.

\section{2 - Percepção}

A base da pesquisa aplicada neste estudo é a avaliação perceptiva de um problema e, inicialmente, serão discutidos conceitos do que é considerado percepção. Na Psicologia Experimental, em seus diferentes estudos, é definida como a capacidade acentuada de discriminar estimulos sensoriais. Entretanto atualmente o termo percepção vem sendo utilizado em áreas diferentes da psicologia e, também, na linguagem popular, o que tem levado à geração de conceitos e interpretação variados.

Em termos gerais a percepção é o resultado de um processo iniciado por um estimulo externo ao organismo. O organismo torna-se consciente deste estimulo, através dos significados das células nervosas receptoras que são sensiveis a formas especificas de energia, tais como luz, som e temperatura. Quando essas fontes de energia são suficientemente fortes para estimular as células receptoras, admitindo-se que o organismo pode ou não se tornar consciente desse estimulo, este processo se refere à 
sensação; quando um número de sensações são colocadas juntas no cérebro, por um processo intermediário, de modo que as pessoas se lembram ou organizam o modelo dessas sensações, este processo é chamado percepção ( Fisher et al., 1984).

De acordo com a tradição construtiva, a percepção consiste em um processo de informação através de deduções ou construções de significados das sensaçōes presentes e lembranças de sensaçōes passadas. Outra conceituação referente a este termo, também pertencente a uma abordagem convencional seguindo, entretanto, uma linha "funcionalista ", expõe que o processo perceptual é moldado pela necessidade do organismo de "conviver" com o ambiente.

\subsection{1 - Percepção Ambiental}

$O$ interesse em mencionar os conceitos acima tem como objetivo favorecer a compreensão do que seja a percepção ambiental. Ela inclui componentes cognitivos, afetivos, interpretativos e avaliativos, todos eles operando simultaneamente (Fisher et al., 1984).

Entretanto, é questionado se a percepção do ambiente não apenas é mais complexa mas apresenta, também, uma complexidade diferente quando se analisa a situação de como e onde ela ocorre. Primeiramente o ambiente produz informações que são conduzidas por padrões de mensagens sensoriais que não são especificas para canais sensoriais particulares; segundo, os ambientes são ilimitados e envolvem as pessoas, induzindo-as mais a explorá-los do que propriamente apenas a observá-los. Assim, pode-se concluir que a percepção do ambiente pode não ser

imediata mas requer um armazenamento na memória, transitório ou permanente, e a integração das mensagens de informação vindas de várias fontes; terceiro, a informação no ambiente necessita ser selecionada e a relevância e a realidade da informação tem que ser julgada pois, em qualquer momento, o número de informações recebidas é maior do que aquele que pode ser assimilado, e ainda existem informações que podem 
ser simultaneamente redundantes e inadequadas; quarto, os ambientes são vistos como parte das atividades sociais e possuem qualidades afetivas e estéticas que são percebidas holisticamente. Por último os fatores cognitivos tais como 0 armazenamento de experiências passadas e 0 armazenamento temporário de informações na memória têm um papel importante na percepção ambiental, participando de julgamentos, decisões e escolhas ( Golledge, 1987).

Segundo Rapoport (1978) a percepção ambiental envolve um conjunto de atitudes, motivações e valores que influem nos distintos grupos sociais na definição do meio ambiente percebido afetando o conhecimento do meio e, também, o comportamento dentro dele. Essa definição não é somente influenciada pela experiência e pelo passado cultural mas, também, por aspirações e expectativas.

Portanto, o meio ambiente não é algo externo e não tem uma forma estática e constante para ser percebido pelo homem. As pessoas e o seu meio estão em constante intercâmbio ativo, sistemático e dinâmico. ambiente é experimentado pelo individuo, através de todos os seus sentidos, podendo entender-se que a percepção total do meio é uma resposta ao meio exterior sócio-físico e ao meio interior (motivação, atenção, saúde etc.). Rapoport (1978) descreve, de forma clara, identificando o homem imerso no meio ambiente respondendo ao seu significado através do seu som, odor, textura, temperatura e visão

Portanto os sentidos exercem um papel fundamental nesta experiência e para se ter uma percepção espacial plena é necessário que o individuo seja, ao mesmo tempo, polisensorial.

\subsection{2 - Percepção auditiva}

A questão da percepção da qualidade ambiental, especificamente da sonoridade vem sendo um dos tópicos mais desenvolvido na literatura da psicologia ambiental. Entretanto diversas abordagens vem sendo feitas sobre $o$ assunto podendo-se subdividi-las em três categorias: pesquisas 
fisiológicas que tratam dos efeitos do ruido sobre o aparelho auditivo; pesquisa senso preceptivas que realizam estudos para determinar limiares de respostas estimulos especificos; e pesquisas sobre os estados psicológicos, que adotam uma abordagem social e ambiental (Gouveia, 1991).

A percepção auditiva envolve a recepção e a interpretação dos estímulos sonoros através do sentido da audição e é um processo altamente complexo e elaborado percebido nos centros auditivos do cérebro. É possivel identificar-se alguns dos componentes da percepção auditiva, segundo Boothroyd (1986) citado por Russo et al.(1993 p.1): detecção, sensação sonora, discriminação, reconhecimento, compreensão, atenção e memória.

A detecção ocorre quando pelo menos um dos componentes tonais encontra-se na faixa de frequências entre 20 e $20000 \mathrm{~Hz}$ e tem amplitude suficiente para provocar um efeito significativo nos modelos de estimulação elétrica no nervo auditivo; a sensação sonora é a impressão subjetiva deixada pelo estímulo sonoro, representada, principalmente, através de três dimensōes: sensação de frequência - "pitch", sensação de intensidade "loudness" e sensação de qualidade - o timbre; a discriminação é o processo de diferenciação de sons acusticamente similares, mas com frequência, duração e/ou intensidade diferentes; o termo localização referese aos julgamentos relacionados à direção e à distância da fonte sonora; o reconhecimento é a identificação correta dos dados sensoriais baseada em conhecimento previamente adquirido, isto é, na experiência; a compreensão é a interpretação de uma nova combinação de modelos sonoros e permite ir além dos limites da experiência; a atenção consiste no processo de monitorização do sinal acústico para atribuir-lhe um significado; finalmente a memória permite reter, armazenar e evocar informações recebidas sendo que o processamento adequado dos dados sensoriais e seu armazenamento será utilizado e aperfeiçoado futuramente ( Russo et al., 1993).

O ruido, como foi discutido em todos os seus conceitos, caracterizase como um som indesejado e dificilmente gera atenção ou atração por sua 
qualidade. Entretanto, embora apresente essa característica, ele é percebido pelo sentido da audição que vai processá-lo fisiologica e psicologicamente envolvendo processos de grande complexidade.

Assim a percepção auditiva é parte de um processamento que envolve uma análise complexa do sinal acústico, integrando a informação em modelos auditivos. É um processo adaptável, modificável e influenciado pela aprendizagem segundo Sloan (1991) citado por Russo et al.(1993 p.3). Considerando o próprio envolvimento sensorial no processo da percepção, pode-se prever a dificuldade de se esperar um comportamento e uma reação uniformes de um determinado grupo diante da complexidade e da especificidade do sistema nervoso de cada ser humano. Em se tratando da percepção ambiental, ela é mais complexa pois envolve o homem interagindo com a dinâmica do seu meio ambiente real.

Estudos vem sendo realizados quanto a variáveis que influenciam na percepção do barulho, sendo até agora a intensidade do estímulo sonoro a mais pesquisada, havendo ainda, entretanto discussões na literatura sobre esta questão.

Outra variável, que também vem sendo pesquisada como influente na percepção do incômodo ao ruido tem sido a satisfação com a moradia. Existem estudos, que levantam a associação entre as pessoas menos incomodadas com o ruido e aquelas mais satisfeitas com a moradia

Considerando a complexidade de uma avaliação perceptiva os resultados desta pesquisa são importantes e se aproximam mais da realidade, abrindo possibilidades de uma maior generalização do comportamento humano em seu meio ambiente.

\section{3 - Fontes do Ruído Urbano}

$O$ ruido atua como um elemento poluente em diversas situações dentro da sociedade moderna. Ele pode ser produzido pelo próprio processo dos meios de comunicação, sistemas de transporte, aparelhos de uso 
doméstico, construções, ambiente de trabalho, veiculos, tráfego urbano, atividades de recreação e ambientes educativos.

As principais fontes de ruído, considerando sua origem, são classificadas em: fontes fixas - indústria, comércio e construção civil; fontes móveis - veículos automotores, tráfego de veículos e aeronaves; fontes diversas - animais ruidosos, música indesejada, bares, restaurantes, cultos religiosos e residências.

O trânsito de veículos constitui uma das mais importantes fontes de ruido. Destacam-se o ruido de aviões, por sua enorme amplitude, localizado em zonas de aeroporto e corredores aéreos; o ruido ferroviário e o ruido do transporte terrestre motorizado que tem como fonte: automóveis, motocicletas, ônibus e transporte de carga.

$O$ ruido provocado pelo tráfego de veículos automotores tem sido considerado, indiscutivelmente, através de vários estudos, como a maior fonte de poluição sonora no meio urbano. Esse fato é decorrente do rápido crescimento da frota circulante nas últimas décadas, o que tem intensificado significativamente o problema.

Considerando os resultados obtidos em pesquisa realizada pela PA (Environmental Protection Agency, 1981), citado por Sutter (1991, p.13) que nos Estados Unidos da América o ruído do tráfego é realmente a maior fonte de ruido no meio urbano, como é apresentado na Tabela 2.

Tabela 2 - Resumo da população americana exposta ao nível médio de ruido diário.

\begin{tabular}{ccccccc}
\multicolumn{6}{c}{ Número estimado (em milhōes) para população em cada nivel de categoria } \\
\hline $\begin{array}{c}\text { DNL } \\
\text { (dB) }\end{array}$ & $\begin{array}{c}\text { Tráfego de } \\
\text { automóveis }\end{array}$ & Aviões & Construção & Trem & Indústria & Total \\
\hline$>80$ & 0.1 & 0.1 & -- & -- & -- & 0.2 \\
$>75$ & 1.1 & 0.3 & 0.1 & -- & -- & 1.5 \\
$>70$ & 5.7 & 1.3 & 0.6 & 0.8 & -- & 8.1 \\
$>65$ & 19.3 & 4.7 & 2.1 & 2.5 & 0.3 & 27.8 \\
$>60$ & 46.6 & 11.5 & 7.7 & 3.5 & 1.9 & 63.6 \\
$>55$ & 96.8 & 24.5 & 27.5 & 6.0 & 6.9 & $92.4^{\star}$ \\
\hline
\end{tabular}

Fonte -EPA (1981:13) citado por Sutter; p. 13 ( 1991)

(1) DNL - média anual de ruído externo.

(2) Existe superposição entre as populações expostas a diferentes fontes de ruido. 
Lopez ( 1998 ), no desenvolvimento de um estudo sobre o impacto da poluição sonora em uma população, buscou como referência principal de seus resultados a avaliação da própria comunidade. A área de estudo compreendeu 17 municipios da comunidade de Madri, obtendo-se no total sete mil cento e quarenta e três entrevistas. Entre seus resultados observouse que o ruido do tráfego urbano foi, comprovadamente, a maior fonte de poluição sonora, seguida pelo ruído de vizinhança (22\%), e pelo ruido de execução de obras $(11 \%)$ como fontes principais na área de estudo analisada.

As fontes de ruído em vias terrestres podem ser divididas em duas categorias principais: o ruido do motor e do escapamento, e o ruido do atrito entre os pneus e o pavimento (Murgel, 1998).

O ruido do motor e do escapamento é determinado, basicamente, pelo nivel tecnológico e pelo modo de operação dos veículos. As recentes leis de controle de emissão de ruido têm obrigado os fabricantes a desenvolverem veículos menos ruidosos. A influência da via, sob este aspecto, está relacionada com as condições gerais de tráfego e da topografia, sendo emitido maior nivel sonoro nos trechos de maior movimento, sinuosos e em aclive (Murgel, 1998).

O ruido gerado pelo atrito entre pneus e pavimento está diretamente relacionado com a velocidade desenvolvida, com a rugosidade do pavimento e com o tipo de pneus utilizados (Murgel, 1998)

Além dos elementos acima mencionados como fontes de ruido, não se pode desconsiderar que a qualidade do tráfego, diante de suas variáveis como volume, fluxo e operação, tem um papel representativo no aumento da intensidade dos niveis de ruido provocado por veiculos.

\section{4 - Características do Ruido do Tráfego Urbano}

Uma das principais caracteristicas do ruido é ser temporal em sua existência e em de sua intensidade. O ruido do tráfego urbano apresenta essas caracteristicas estando, portanto, sempre dependente do 
comportamento, dos hábitos e da periodicidade e dos tipos de atividades desenvolvidas pela população nas cidades, ao longo do dia, da semana, do mês e até mesmo do ano. Todas elas interferem diretamente no dimensionamento do volume de tráfego que ocorre nas vias urbanas.

Segundo EPA (1974b, p.5) citado por Sutter (1991), pesquisas realizadas revelam, também, que o nivel de ruido em uma comunidade está diretamente relacionado com a densidade populacional. O ruido em áreas urbanas é, geralmente, superior ao de áreas rurais. Hoje, nos Estados Unidos da América, o problema do ruido vem aumentando, no mínimo, na mesma proporção da urbanização e de modo mais acelerado que o crescimento da população.

O tráfego urbano caracteriza-se por apresentar os periodos denominados de pico e entre-pico. Os periodos de pico são considerados aqueles que apresentam maior volume de tráfego por hora e o periodo entre-pico aquele que apresenta uma maior estabilidade e menor volume de tráfego de veículos em uma determinada via. Pode-se prever, consequentemente, que a emissão do maior nivel de ruido acontecerá nos periodos de pico

A via urbana é o instrumento básico na geração da acessibilidade nas cidades. O sistema viário está sempre integrado ao uso e ocupação do solo e presente de modo intenso em qualquer área urbana. Entretanto a hierarquia proposta no sistema viário e o próprio planejamento urbano são os principais fatores na determinação do volume de tráfego ao longo das vias. A existência de incompatibilidade na definição do uso e ocupação do solo de uma determinada área, com a hierarquia proposta no sistema viário já é um fator que gera o surgimento de incômodo do ruido à população.

Palhares et al. (1998) desenvolvem um estudo, na cidade de Belo Horizonte, que tem como objetivo a realização de um mapeamento dos niveis de pressão sonora equivalente (Leq) provocados pelo ruido do tráfego veicular. O objetivo geral deste estudo é o de correlacionar o incômodo provocado pelo ruido de tráfego com as caracteristicas de padrōes de uso do solo urbano, rede viária e perfil do tráfego veicular. Através dos 
resultados e da metodologia aplicada, constata a presença de maior intensidade de ruido nas vias com as seguintes caracteristicas: maior volume de tráfego; vias mais estranguladas, com falta de espaços abertos; regime de tráfego mais interrompido por semáforos; congestionamentos; velocidades mais baixas; maior proporção de veículos pesados na composição de tráfego na hora de pico. É, também, observado o comportamento diferenciado dos niveis de ruido para um mesmo local em função do perfil do tráfego para o pico da manhã ou da tarde. Constata ainda a presença de ilhas de silêncio com niveis de ruido bem abaixo do máximo permitido pela legislação e que quase toda área de estudo apresenta-se afetada por niveis ruido de $1 \mathrm{~dB}$ até $11 \mathrm{~dB}$ acima do permitido.

Um outro estudo foi desenvolvido na cidade de Belo Horizonte, buscando analisar o impacto da melhoria das condições de tráfego em um corredor de transporte urbano, no que se refere ao conforto acústico na comunidade presente em sua área lindeira. Valadares et al. (1998) adotam como hipótese que a melhoria nas condições de serviços de tráfego para os motoristas e usuários do sistema viário representa, entre outros beneficios, menor tempo e, portanto, maior velocidade média de viagem nos percursos. Entretanto como conseqüência, há um aumento dos niveis de ruido emitidos pelos veículos, considerando que o nivel da potência sonora dos veículos é maior com o aumento da velocidade de tráfego.

Como conclusão é verificado que os pontos qualificados como os de melhor nivel de serviço são aqueles que a comunidade, através de atitudes enérgicas, reporta como os pontos de maior poluição sonora. Assim, o aumento da velocidade do fluxo do tráfego pode gerar um aumento na emissão de ruido. O controle da velocidade permitida em uma via pode ser, portanto, considerado como um instrumento mediador para minimizar o nível de ruido presente nas vias.

Observa-se que neste estudo foram considerados vários fatores, que interagem conjuntamente na definição da emissão do nivel do ruido do tráfego urbano, tais como velocidade, qualidade do tráfego e via e, ainda, um 
outro fator de grande importância, embora de caráter subjetivo, que se refere à percepção e à identificação do problema pela própria população.

O ruido do tráfego urbano apresenta especificidades próprias nos aspectos espacial, temporal, tecnológico, social e psicológico que já o diferencia dos demais tipos de ruido. Assim, a abordagem do assunto requer a consideração de todas as variáveis envolvidas no processo de emissão do ruido, tais como: duração, intensidade, percepção e seus efeitos.

Existem atividades que requerem maior silêncio e/ou solicitam maior tempo de permanência do individuo, como aquelas desenvolvidas em zonas de trabalho e de residência que, muitas vezes, estão localizadas de forma incompativel com o tipo de via existente nas suas proximidades.

\section{5 - Controle da Emissão do Ruído do Tráfego Urbano}

O controle do ruido pode ser obtido por três vias distintas: redução do ruido da fonte, limitação da transmissão do som ou isolamento do receptor.

A redução da intensidade do ruído do tráfego urbano, na fonte, envolve a análise de todos os elementos que interagem e atuam conjuntamente na sua emissão. Isso implica na necessidade da avaliação tecnológica do próprio veículo, tipo de pavimentação utilizado na pista, tipos de veiculos que circulam, volume do tráfego no qual estão inseridos, periodo de tempo em que acontece, como ainda o planejamento quanto ao uso e ocupação do solo da área.

A redução da produção do ruido nos veiculos tem sido um desafio para o desenvolvimento da engenharia produtiva. As leis estão, cada vez mais, exigindo redução do nivel de ruido emitido pelos veículos em seu processo de fabricação.

Quanto ao tipo de pavimento sabe-se que o pavimento de concreto gera um acréscimo do nivel de ruido em cerca de $2 \mathrm{~dB}(\mathrm{~A})$ mais que o asfalto convencional, não sendo recomendável em trechos urbanizados próximos a 
residências. O uso do asfalto de baixa rugosidade acarreta uma redução do nível sonoro em até $3 \mathrm{~dB}(\mathrm{~A})$ (Murgel, 1998).

O controle da velocidade do tráfego é outro instrumento que pode ser utilizado como delimitador do ruido. Aumentando-se a velocidade, os motores passam a operar em maiores rotações e, proporcionalmente, geram um aumento do ruido do atrito entre pneus e pavimento. Limitando-se a velocidade máxima em $80 \mathrm{~km}$ para automóveis e $60 \mathrm{~km}$ para caminhões, gera-se uma redução do nivel do ruído em cerca de 2 dB(A) (Murgel, 1998)

Trabalhando-se, conjuntamente, com a redução da velocidade e com o uso de pavimento asfáltico de baixa rugosidade, pode-se abaixar o nivel de ruído em até $5 \mathrm{~dB}(\mathrm{~A})$.

A utilização da alternativa de isolamento do receptor, considerando a tipologia predominante das edificações nos centros urbanos, envolve a utilização de materiais isolantes nas fachadas, tais como janelas de vidro duplo e outras soluções já existentes. A adoção dessa medida, por parte de uma politica de governo, implica em interferência na propriedade e na iniciativa privadas sendo, portanto, considerada como de última opção Entretanto observa-se que essas soluções vêm sendo adotadas por iniciativa própria de pessoas que convivem com este tipo de problema, para minimizar o incômodo já existente em muitas zonas urbanas.

O controle da transmissão sonora pode ser feito utilizando-se barreiras acústicas ao longo das vias, podendo ser utilizados tanto a própria natureza quanto elementos artificiais. Os meios naturais são utilizados em situações em que as características topográficas locais são aproveitáveis para efeito de barreiras, podendo, ainda, serem criados implantando-se faixas de vegetação alta ao longo das vias. Na última alternativa, para a obtenção de um efeito efetivo, é necessário que se tenha uma alta densidade de vegetação, de pequeno, médio e grande porte, por uma faixa de, no mínimo, $50 \mathrm{~m}$ de largura, o que nem sempre é possível (Murgel, 1998).

As ondas sonoras ao se depararem com um obstáculo podem ser refletidas, absorvidas ou refratadas. As barreiras acústicas possuem a 
finalidade de impedir a livre propagação do som levando a uma redução do ruido bem maior do que ocorreria em condições naturais. O nivel de efetividade dessas barreiras depende do tipo de material utilizado, sua forma, altura e posição relativa à fonte sonora. A parte refletida seguirá em direção oposta; a parte absorvida será dissipada, sendo que uma pequena parte dela será transmitida e a parte refratada contorna o obstáculo e atua como uma nova fonte de menor intensidade. A parcela de ruído a ser absorvida dependerá da densidade superficial do material empregado, podendo favorecer uma redução entre 25 e 45 dB(A) (Murgel, 1998).

Portanto a capacidade de redução sonora de uma barreira, seja natural ou artificial, vai depender de vários fatores: localização, geometria e material empregado.

O controle do ruido poderá, também, ser feito a partir de alteração de normas de uso e ocupação do solo, diversificação de alternativas na circulação do sistema viário, buscando reduzir o volume de tráfego em determinadas vias e também através de legislação.

Observa-se que existem opções de controle do nivel de ruido emitido pelo tráfego urbano. Entretanto têm-se constatado dificuldades em adotálas devido ao fato de que quando se constata a presença do ruído do tráfego urbano como incômodo, já se tem um ambiente totalmente construido, o que resulta em grandes limitações nas medidas de controle possiveis.

\section{6 - Efeitos do Ruído de Tráfego Urbano}

Os efeitos do ruido urbano e, principalmente, do ruido do tráfego urbano têm sido um assunto historicamente discutido. Muitas pesquisas já foram e ainda são realizadas sobre a questão. Entretanto a dificuldade de comprovação do ruído urbano como causa de uma doença especifica tem dificultado a conclusão e a generalização dos resultados obtidos em muitos estudos realizados. A invisibilidade, a temporalidade e o comportamento não uniforme, caracteristico do ruido, talvez, sejam fatores que contribuam para esta situação. 
A discussão dos efeitos do ruido na saúde humana encontra-se apresentada, de forma mais detalhada, no capítulo 6 .

Estudos demonstram que a perda ou redução da capacidade auditiva do homem, como efeito de exposição ao ruído, na maioria dos casos, acontece quando se tem uma exposição a um nivel superior a $80 \mathrm{dBA}$. O efeito da exposição a um determinado nivel de ruído será sempre analisado relacionando-o com o tempo e a intensidade do ruido ao qual foi exposto, para que sejam determinadas as possibilidades de riscos de comprometimento da audição. Essas situações são mais freqüentes em ambientes de trabalho.

As zonas residenciais caracterizam-se como áreas onde a população busca ter maior tranquilidade, pois são áreas particulares de grande permanência e onde há o desenvolvimento de atividades que suportam menor intensidade de ruido. São também áreas predominantes no meio urbano.

Outro estudo realizado por Mendes et al.(1998) em zonas residenciais na cidade La Plata , constituiu-se de medições e aplicação de questionários. A área apresentava, no período da manhã, nivel de ruido máximo (Leq) de $78,9 \mathrm{~dB}(\mathrm{~A})$ e mínimo de $68,6 \mathrm{~dB}(\mathrm{~A})$. Vários pontos de estudos superavam o valor de $70 \mathrm{~dB}(\mathrm{~A})$. Os resultados obtidos, através dos questionários, demonstraram a existência do incômodo revelado pela comunidade local. Dentre os moradores $81 \%$ consideram o ruido que os afeta como muito forte $(35 \%)$ e forte $(46 \%)$.

Todas essas situações revelam que o ruido do tráfego urbano constitui um problema comum e frequente nas cidades, gera grandes impactos na população, mas está ainda fora do controle do governo e da própria comunidade.

Observa-se a necessidade de se dar maior importância ao problema, desenvolvendo e priorizando os estudos de campo sobre a poluição sonora nas áreas urbanas.

É necessário o desenvolvimento de políticas de planejamento, buscando detectar e proteger as zonas urbanas, prevendo um adequado 
nivel de ruido nos vários setores. Deverão ser desenvolvidas através de estudos utilizando-se de equipes multidisciplinares, para melhor elaboração de códigos e planos urbanos, buscando assim minimizar fatores distintos que possam afetar a paisagem acústica.

\section{7 - Legislação}

Existem alguns padrões para definir o nivel de permissividade ou os niveis permissiveis relacionados ao tempo de exposição ao ruído quando são discutidas as atividades ocupacionais, principalmente, em áreas de trabalho. Entretanto, quanto à exposição ao ruído de fontes de ambientes externos, não existem normas relacionando tempo de exposição, nivel de ruido e danos à saúde.

Admitindo-se ser o tráfego urbano a maior fonte de ruido urbano, limites vem sendo estabelecidos, através de legislação em todos os países, e buscam cada vez mais reduzir a intensidade de ruidos produzidos pelos veiculos.

A fabricação de veículos vem sendo fiscalizada, quanto aos impactos ambientais que podem causar os seus produtos, e leis vem sendo elaboradas para exigir e obter controle do nivel de emissão de ruido permitido.

Os paises do primeiro mundo apresentam legislação para testes de emissōes de ruido. Os limites e os métodos desses testes, nos paises europeus, são os mais rigidos. Nesses paises, considerando o histórico da legislação que define os limites de ruido nos últimos anos, observa-se que para os veículos de passeio: entre 1970 e 1975, tinha-se como limite 84 $\mathrm{dB}(\mathrm{A})$; 1975-1984 limite de $82 \mathrm{~dB}(\mathrm{~A})$; 1984-1990 limite de $80 \mathrm{~dB}(\mathrm{~A})$; 1990 1994 limite de $77 \mathrm{~dB}(\mathrm{~A})$. O mesmo processo de redução de tolerância ao ruido foi efetuado para os caminhões: 1970-1975 limite de $92 \mathrm{~dB}(\mathrm{~A})$; 1975 1984 limite de $91 \mathrm{~dB}(\mathrm{~A})$; 1984-1991l imite de $88 \mathrm{~dB}(\mathrm{~A})$; 1991-1994 limite de $84 \mathrm{~dB}(\mathrm{~A})$ (Albers et al., 1994).

O Brasil tem adotado alguns dos procedimentos de legislação e de limites estabelecidos pelos paises europeus. Os principais são dados pelas 
normas NBR 10151 e NBR 10152 da Associação Brasileira de Normas Técnicas e pela resoluções 001 de 11/02/93 (Conselho Nacional de Meio Ambiente - CONAMA, 1993) e 002 (CONAMA, 1990b)

A norma NBR-10152 (Associação Brasileira de Normas Técnicas ABNT,1987b) refere-se à definição de niveis de ruido interno aceitáveis em ambientes especificos em zonas de uso urbano, tais como: hospitais, escolas, hotéis, residências, auditórios, restaurantes, escritórios, igrejas e templos e locais para esporte, assegurando a qualidade ambiental e o conforto desses ambientes. Niveis superiores aos definidos nas normas são considerados de desconforto, mesmo que não impliquem em risco ou dano à saúde. Recomenda-se para as zonas residenciais: em ambientes como dormitórios, um nivel de ruido no intervalo de 35 a $45 \mathrm{~dB}(\mathrm{~A})$ e para salas de estar o intervalo entre 40 a $55 \mathrm{~dB}(\mathrm{~A})$. Nessa norma, não são apresentados os níveis de ruído permissiveis relacionados aos periodos do dia.

A norma NBR 10151 (ABNT, 1987a) fixa as condiçōes exigiveis para a avaliação da aceitabilidade do ruido em comunidades. Ela especifica um método para a medição de ruido e a aplicação de correções nos niveis medidos considerando a duração, características espectrais e fator de pico. Como critério geral, esta norma define o nivel de $45 \mathrm{~dB}$ (A) para as zonas residenciais e indices de correções de critério básico $(C p)$ para os diferentes periodos do dia e também para as diferentes zonas de uso $(\mathrm{Cz})$. O primeiro, $\mathrm{Cp}$, tem o valor zero para o periodo diurno e -5 para o periodo noturno. Os valores de correções do critério básico para uso residencial em zonas de hospitais $\mathrm{Cz}=0$, para as zonas residenciais urbanas $\mathrm{Cz}=+10$, em centros de cidade $\mathrm{Cz}=+20$ e em área predominantemente industrial $\mathrm{Cz}=+25$. Portanto, na definição do critério de nivel de ruído permitido, todos esses fatores são considerados, aplicando-se a fórmula $45+C p+C z$ para obter-se o nivel de ruido final, ou melhor, o nivel permitido nas respectivas áreas.

Concluindo sobre a norma que define o nivel de ruido em áreas que oferecem o uso residencial, tem-se que: para as zonas exclusivas para o uso residencial os niveis permitidos para o periodo diurno e noturno serão, respectivamente, $55 \mathrm{~dB}(\mathrm{~A})$ e $50 \mathrm{~dB}(\mathrm{~A})$; para as zonas de uso hospitalar, os 
niveis de ruido permitidos para $o$ período diurno e noturno são respectivamente $45 \mathrm{~dB}(\mathrm{~A})$ e $40 \mathrm{~dB}(\mathrm{~A})$; para as áreas de centro de atividades terciárias os niveis permitidos para o periodo diurno e noturno são, respectivamente, $65 \mathrm{~dB}(\mathrm{~A})$ e $60 \mathrm{~dB}(\mathrm{~A})$ e nas áreas residenciais situadas nas zonas previstas para uso industrial ter-se-ia para o período diurno o nivel de ruido de $70 \mathrm{~dB}(\mathrm{~A})$ e $65 \mathrm{~dB}(\mathrm{~A})$ para o periodo noturno.

Considerando que os problemas dos niveis excessivos de ruido estão incluidos nos aspectos sujeitos ao controle da poluição de meio ambiente e que os critérios e padrões deverão ser abrangentes e de fácil aplicação em todo o território nacional, o Conselho Nacional de Meio Ambiente - CONAMA atua na elaboração de resoluções e normas de modo a obter controle do problema.

A Resolução nº 001 (CONAMA, 1990a), implantada em 8 de março de 1990, considera prejudicial à saúde a exposição a niveis de ruído superiores àqueles definidos pela NBR-10152 (ABNT, 1987b) e ressalta a obrigatoriedade no atendimento a essa resolução. Ela concede às entidades e órgãos públicos (federais, estaduais e municipais) competentes para o uso do respectivo poder politico, dispondo de acordo com o estabelecido na resolução sobre a emissão e proibição de ruido de forma a garantir a saúde, a qualidade de vida e o sossego público. Torna-se obrigatório que as medições de ruido atendam as exigências da NBR 10.151 (ABNT, 1987a).

A Resolução $n^{\circ} 002$ (CONAMA, 1990b) de 08/03/1990 institui o Programa Nacional de Controle da Poluição Sonora - Silêncio, que tem como principais objetivos: divulgar para a população os efeitos prejudiciais causados pelo excesso de ruido, capacitar pessoal técnico para o controle da poluição sonora, incentivar a capacitação de recursos dentro das polícias civil e militar para recebimento de denúncias $e$ incentivar $o$ uso e a fabricaçāo de equipamentos com menor nivel de intensidade sonora.

Em 11 de Fevereiro de 1993, admitindo serem os veículos rodoviários automotores as principais fontes do ruido no meio ambiente e ser a redução da poluição sonora necessária nos centros urbanos, é implantada a Resolução $n^{\circ} 1$ (CONAMA, 1993a). Ela estabelece para veículos 
automotores nacionais e importados limites máximos de emissão de ruído para veículos em aceleração e na condição de parado, prevendo o atendimento a essa resolução por no mínimo: $20 \%$ dos veículos produzidos a partir de $1994,50 \%$ a partir de 1995 e que venha a ser atendido por todos os veiculos a partir de 1997.

No mesmo ano, diante da necessidade de atualização do Programa de Controle da Poluição do Ar - PROCONVE - (Instituto Brasileiro do Meio Ambiente e dos Recursos Naturais Renováveis - IBAMA, 1998) foi publicada a Resolução nº 8 (CONAMA, 1993b) em 31 de Agosto de 1993. Nessa resolução, através de seu artigo 20 , ela substitui o artigo $1^{\circ}$ da Resolução $n^{\circ}$ 1 (CONAMA, 1993a) de 11/02/1993, estabelecendo para os veículos automotores nacionais e importados limites máximos de ruido com o veículo em aceleração e na condição de parado, prevendo que a partir do ano de 1997 todos os veículos estejam atendendo os limites definidos na Tabela 3

Através dessas medidas, têm-se as normas de controle da emissão de ruido para as zonas urbanas em uma esfera federal, permitindo aos estados adequá-las às suas necessidades.

Quanto ao controle do problema pelo governo local, medidas vêm também sendo estabelecidas. O Governo do Distrito Federal (DF), em 11 de Dezembro de 1992, sancionou a lei $n^{\circ} 380$ (D.F, 1993), cujos artigos definem: horários de funcionamento de carro de som; multas em caso de transgressão e niveis sonoros a serem atendidos em zona residencial urbana, centro da cidade e zona industrial. Segundo definição desta lei ficou determinado como nivel de ruído máximo para área residencial urbana o indice de $55 \mathrm{~dB}(\mathrm{~A})$, para a área central da cidade $65 \mathrm{~dB}(\mathrm{~A})$ e para áreas de uso industrial $70 \mathrm{~dB}(\mathrm{~A})$.

Posterior à lei $n^{\circ} 380$ citada, o Governo do Distrito Federal sancionou a lei $n^{\circ} 1065$ em seis de maio de 1996 (DF,1996). Essa lei estabelece as normas de preservação ambiental quanto à poluição sonora, fixando niveis máximos de emissão de sons e ruidos de acordo com o local e a duração da fonte. 
Tabela 3 - Limites máximos de emissão de ruido para veiculos automotores

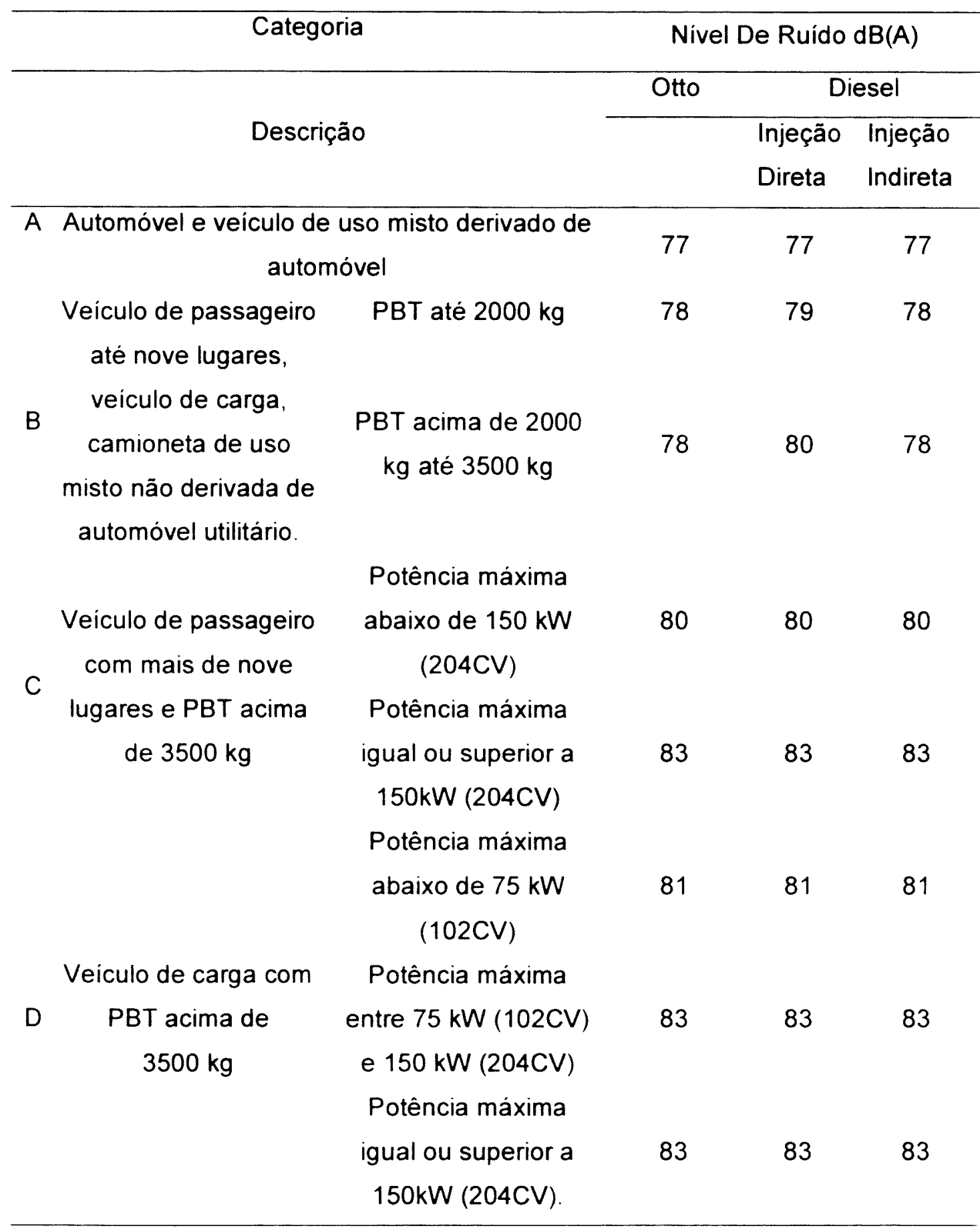

PBT: Peso Bruto Total

Potência: Potência liquida máxima ( NBR 5484)

Fonte - Resolução CONAMA n ${ }^{\circ}$, 31/08/1993

Nessa lei, os niveis de ruido máximos permitidos, em ambientes internos e externos, estão relacionados àqueles fixados pela NBR 10151 
(ABNT, 1987a). Observa-se, portanto, que quanto a este aspecto, os niveis de ruido permitidos no Distrito Federal sofreram alterações comparados aos niveis fixados anteriormente, pela lei $n^{\circ} 380$.

O artigo 13 da lei $n^{\circ} 1065$ (D.F, 1996) concede à Secretaria de Meio Ambiente, Ciência e Tecnologia - SEMATEC: o poder de estabelecer normas de controle e redução da poluição sonora do DF; o poder de fiscalização e de policiamento, quando necessário; o de executar programas de monitoramento, educação e conscientização da população.

No artigo 14, a Secretaria de Saúde é incumbida da implantação de programa de monitoramento de niveis de audição da população e da realização de exames auditivos em escolas.

Considerando os serviços, que vêm sendo realizados pela SEMATEC, referentes à poluição sonora no DF, ressalta-se a fiscalização quanto ao atendimento à lei, no que se refere a reclamações de vizinhanças, quando ocorre emissão de ruídos externos excessivos, comprometendo a qualidade de vida dos moradores. 


\section{6 - ANÁLISE DOS EFEITOS DO RUÍDO DO TRÁFEGO URBANO NA SAÚDE HUMANA}

O objetivo deste capitulo é discutir e identificar os possiveis efeitos negativos à saúde humana que resultem da exposição das pessoas ao ruido do tráfego urbano. Uma das questões a ser respondida seria se o nivel do ruído do tráfego urbano é prejudicial à saúde e ao bem estar daqueles que residem em áreas urbanas

O conceito de saúde considerado no contexto desta pesquisa é aquele da Organização Mundial de Saúde (WHO, 1963) citado por Burns (1969, p.113) segundo o qual saúde é "o estado de bem estar social, mental e fisico e não meramente a ausência de qualquer doença"

Portanto a preocupação nesta discussão é esclarecer os impactos do ruido urbano na saúde humana. $O$ interesse é identificar que tipos de efeitos ou doenças poderiam ser investigados como conseqüencia do ruído. $O$ tráfego de veiculos, como discutido no capitulo anterior, é a maior fonte de ruido no meio urbano e, como tal, tem suas caracteristicas especificas, que o diferencia das demais.

O ruido urbano apresenta diferentes niveis sonoros (Leq) durante o dia, estando relacionado diretamente com as atividades desenvolvidas e o comportamento da população no meio urbano. A variação do nivel de ruido gerado pelo tráfego urbano está associada à intensidade de deslocamentos da população e também aos periodos em que eles são realizados Diante disso a caracterização do comportamento do tráfego urbano deve considerar os horários de pico - os que apresentam maior volume de tráfego nas vias e portanto o periodo de maior número de deslocamentos de veículos e os horários entre-pico - em que se tem um menor volume de tráfego circulando.

No Brasil, os periodos de pico acontecem pela manhã, nos horários de ida para o trabalho e escolas, (entre $6 \mathrm{~h}$ e $9 \mathrm{~h}$ ), e no horário de volta para casa (entre $17 \mathrm{~h} 30 \mathrm{~min}$ e $19 \mathrm{~h}$ ). Muitas cidades brasileiras têm ainda o horário do almoço, (entre 11h45min e 14h), como periodo de pico.

No período da noite, tem-se como comportamento padrão o nivel de ruído baixo e próximo ao silêncio, em decorrência de um número menor de 
atividades. O mesmo já não acontece nos periodos da manhã e no final da tarde, durante os horários do pico do tráfego, em que apresenta, consequentemente, niveis de ruido mais altos.

O tempo de permanência nas áreas residenciais e o tempo de exposição ao ruído de tráfego nessas áreas são diferentes de pessoa para pessoa. Também é relevante considerar que várias atividades são desenvolvidas ao longo do dia e que as pessoas podem apresentar diferentes niveis de tolerância ao ruido para executá-las.

O conceito de ruido levanta discussões sobre as suas propriedades. Segundo Stansfeld admitir que o ruído seja algo distinto de um som de música ou fala é admitir, consequentemente, a presença de componentes psicológicos; o ruído visto como um som indesejado, implicando na determinação dele ser ou não indesejado, é um processo subjetivo e de ordem psicológica ( Stansfeld, 1993a).

Ao ruido pode ser atribuido um componente psicológico, onde o seu significado particular e o contexto em que ele acontece são relevantes na determinação de seus efeitos (Cohen et al., 1981). Sendo assim, na medição da intensidade do ruido deve-se considerar, como de grande relevância, a sua qualidade e seu significado subjetivo. As caracteristicas pessoais, culturais e sociais também são fatores importantes na definição de um som que venha a ser qualificado como ruido.

O ruido urbano varia espacial e temporalmente nas cidades e consequentemente nas áreas residenciais. Cada setor urbano geralmente apresenta características especificas de comportamento. Essas caracteristicas estão vinculadas ao nivel de desenvolvimento, projeto $e$ planejamento urbano das cidades onde se encontram inseridos. Todos esses fatores contribuem diretamente na formação do volume, distribuição e comportamento do tráfego urbano ao longo do dia.

Considerando as especificidades do ruido do tráfego urbano, estudos vêm sendo realizados, buscando identificar os seus efeitos na saúde humana. Nesses estudos, são apresentadas diferentes abordagens quanto à questão. Há pesquisas para a identificação de interferências nas 
atividades humanas, pesquisas de laboratórios simulando situações de exposição para possivel identificação de doenças e pesquisas de campo envolvendo ambos os tipos de abordagem.

Burns (1969) classificou os efeitos do ruido urbano em duas categorias: as que podem ocorrer de forma direta e aquelas que podem ocorrer de forma indireta sobre os individuos. Os efeitos diretos envolvem aspectos da percepção do próprio ruído e das conseqüências subjetivas imediatas e incluem o fenômeno da sensação da altura do som, a sensação e a percepção da presença do ruido; interferência imediata na compreensão de uma fala. Os efeitos indiretos incluem a interferência em dormir ou descansar, no incômodo; interferências em atividades tais como trabalho e lazer $e$ os possiveis efeitos na saúde. Os efeitos diretos seriam os fenômenos primários e os efeitos indiretos são as conseqüências da permanência do ruido.

Estudos posteriores foram realizados, comprovando a existência desses efeitos através de pesquisas sobre a intensidade dos danos na saúde humana (Sutter, 1991, Berglund et al., 1995). Abordam e analisam como efeitos não apenas a própria percepção do ruido como também: a sensação de incômodo, a interferência na comunicação, o comprometimento da compreensão de diálogos, do sono, das atividades, do comportamento e psicológico.

Os autores até agora citados não tem a preocupação em identificar qualquer tipo especifico de doença associada à exposição ao ruido de tráfego. São definidos sim, os efeitos do ruido urbano que poderão produzir e interagir, juntamente com outros efeitos provenientes de outras fontes, provocando danos à saúde.

Os estudos sobre os efeitos do ruido do tráfego urbano têm sido desenvolvidos tanto em laboratórios como em campo.

Os experimentos, realizados em laboratórios, são desenvolvidos sob condições definidas, no que se refere ao tempo de exposição e nível de ruido. Este tipo de abordagem apresenta vantagens e desvantagens. A vantagem è a metodologia que lida com condições precisas de uma 
situação especifica ao investigar os efeitos do ruido e a possibilidade dele estar ou não vinculado ao comprometimento da saúde humana. A desvantagem é que os experimentos não são desenvolvidos dentro de um cenário real do ambiente urbano, gerando dificuldades em considerar se os resultados obtidos possam ser válidos também para a exposição direta do tráfego.

As pesquisas de laboratórios dirigem sua atenção para as questões de comportamento e saúde onde a exposição ao ruido pode atuar como causa de problemas na saúde humana.

As pesquisas de campo utilizam-se dos cenários reais onde ocorre o ruido. Elas podem ajudar a comprovar se as consequências ou resultados encontrados em laboratório podem ser detectados na vida real e se possibilitam outros tipos de estudos e propriedades do ruido urbano.

Vera et al. (1994) realizaram duas pesquisas de laboratório para analisar os efeitos psicológicos e subjetivos e as variaçōes cardiovasculares em mulheres submetidas a uma exposiçāo continua ao ruido de tráfego, com o objetivo de identificar a possibilidade de riscos à saúde. O estudo foi desenvolvido com uma amostra de 85 mulheres as quais foram submetidas a um teste psicológico por quinze minutos sob a ação de um nivel de ruido de alta intensidade variando de $85 \mathrm{~dB}$ a $95 \mathrm{~dB}$.

Em ambos os casos, foram analisadas as reações com a presença $e$ a ausência paralela de frases negativas sobre os efeitos do ruido. No primeiro caso, foi concluido que o ruido de tráfego provoca uma tensão subjetiva e respostas psicológicas e que poderia ser um fator de risco para o aparecimento de problemas psicológicos e emocionais. No segundo estudo realizado, no qual, também, foi analisada a possibilidade de ocorrência de problemas cardiovasculares, constatou-se que a presença do ruido gera reações cardiovasculares e subjetivas, podendo, portanto, vir a ser um fator de risco para o aparecimento de problemas cardiovasculares e de ansiedade. 
A presença simultânea de frases negativas quanto aos efeitos do ruído e a própria exposição foi significante, provocando um aumento na intensidade das respostas do segundo estudo.

Evans et al. (1995) realizaram um estudo de laboratório sobre a relação do ruído crônico e o estresse psicológico. Trabalharam com uma amostra de 135 crianças que estavam matriculadas no terceiro e quarto anos do primeiro grau. Todas viviam em uma área no entorno de Munich que apresentava um alto nivel de ruido urbano. A área apresentava no período da noite, no horário de pico, um nivel de ruido (Leq) de 79,6 dB (A) e no periodo entre pico um nivel de ruido (Leq) de $68,1 \mathrm{~dB}(A)$. A pesquisa foi feita em local fechado com controle de som, para que fosse atingido o nivel de ruido previsto na área residencial situada próxima à escola das crianças. Elas foram expostas ao ruido por duas vezes ao dia, por um periodo de 85 minutos. Foi concluido que existe uma reação de estresse psicológico desfavorável associada à exposição crônica ao ruido entre as crianças de primeiro grau.

Considerando os resultados das pesquisas de laboratório que foram apresentadas acima, observa-se que as situações ou cenários utilizados estão distantes da realidade do meio ambiente urbano. Entretanto os resultados mostram que podem surgir interferências negativas nas atividades diárias e problemas psicológicos provenientes de exposição ao ruido urbano.

A pesquisa de campo sobre o ruido do tráfego urbano, como foi colocado anteriormente, tem sido bastante desenvolvida. Nesse tipo de pesquisa procura-se analisar também os efeitos do ruido de tráfego na saúde humana. Considerando os objetivos especificos deste estudo, foram feitas investigações de alguns resultados.

Os estudos desenvolvidos sobre o ruido do tráfego aéreo não foram considerados nesta pesquisa, porque não é uma situação que se apresenta de forma constante e comum à maioria das áreas inseridas no meio urbano. Logo, a análise da reação da comunidade ao ruido de tráfego aéreo pode 
não ser diretamente aplicável para o caso do ruido urbano comum e predominante nas cidades (Fidell, 1978).

Cohen et al. (1973) desenvolveram um estudo para examinar a relação entre a audição infantil e o nivel de ruido existente em suas residências, considerando como principal fonte uma via expressa. Ele trabalha com crianças que moravam em prédios de apartamentos de 32 andares. Observa que o nivel de ruído decresce à medida que se sobe o andar. A pesquisa tinha como objetivo apresentar evidências sugerindo que a capacidade de aprendizagem de habilidades verbais podem estar relacionadas com o tempo de exposição ao nivel de ruido presente em seu ambiente residencial. Os resultados de seu estudo confirmaram a hipótese, sugerindo uma associação entre o nivel de ruido do ambiente familiar e dificuldades em aprendizagem de leitura.

Fidell (1978) realizou um estudo sobre a reação da comunidade à exposição ao ruido tendo como fonte o nivel de ruido proveniente do tráfego da rua. Na seleção das áreas foi evitada a presença de grandes aeroportos e rodovias. Ele trabalhou com ruas que apresentavam niveis de ruido com valores de Leq entre $50,55,60,65,70$, e $75 \mathrm{~dB}$. Esse estudo foi desenvolvido nos Estados Unidos da América, envolvendo sete cidades americanas: Atlanta, Boston, Chicago, Los Angeles, San Francisco, Seattle e Washington. Foram entrevistadas 2037 pessoas por telefone e, também, pessoalmente. Considerando as questōes relacionadas à saúde, conclui que a exposição ao ruído, típica do meio ambiente urbano, provoca um incômodo geral e uma interferência negativa na conversação e no sono.

Weisten (1982) fez uma revisão de estudos disponiveis sobre ruido urbano e encontrou pouca evidência que permita afirmar que há a ocorrência de adaptação da comunidade ao ruído. Ele analisou as reaçōes ao ruído de tráfego associado com a abertura de uma auto estrada em uma comunidade residente em áreas de subúrbio nos Estados Unidos da América. Conclui também que não há qualquer evidência que demonstre uma adaptação razoável aos efeitos do ruido por eles relatados como incômodo. A 
comunidade demonstrou pessimismo quanto à sua capacidade de uma adaptação futura ao ruído.

Outros estudos também vêm sendo realizados e buscam analisar a relação entre o ruido urbano e problemas psicológicos. Stanfeld et al. (1993a) realizaram uma pesquisa para investigar esta relação; a amostra foi primeiramente agrupada, através de testes em pessoas sensiveis e não sensiveis ao ruido. Identificou-se neste estudo que existe uma forte relação e associação entre o nivel de emissão de ruído e o incômodo; quanto maior o nível do ruído maior é o número de pessoas que se sentem incomodadas. O grupo de pessoas sensiveis demonstra ser mais incomodado com a exposição do que os demais. Quanto à relação entre problemas psicológicos e exposição a niveis de ruido, não foi observado uma associação direta. Entretanto foi constatado haver uma forte relação entre pessoas sensiveis ao ruido e a existência de distúrbios psicológicos. Essa associação também foi obtida em estudos anteriores, realizados pelo mesmo autor, em uma amostra do sexo feminino.

Estudo similar foi desenvolvido pelo mesmo autor, em uma amostra masculina onde buscou-se analisar a relação entre o ruido do tráfego urbano e os distúrbios psiquiátricos. Concluiu-se que a exposição ao ruido poderia causar sintomas psicológicos, aumentando o consumo de tranqüilizantes, mas não causa aumento de distúrbios psiquiátricos na comunidade. Portanto não há relação de causa-efeito entre exposição ao ruido e distúrbios psiquiátricos até o momento. Porém foi constatada uma associação entre o grupo de pessoas sensiveis ao ruido e a presença de distúrbios psiquiátricos tendo sido levantada a hipótese de ser a sensibilidade ao ruido um fator de vulnerabilidade para o surgimento de distúrbios psiquiátricos causados pelo ruido (Stansfeld et al. 1993b).

Ohrstrom (1993) realizou estudos utilizando uma amostra composta por 841 pessoas e revelou que o ruído do tráfego urbano (entre 61 a 74.7 $d B(A)$ provoca efeitos significativos ao bem-estar psicossocial, estando diretamente proporcional à intensidade do nivel sonoro e ao tempo de exposição; é responsável, ainda, por distúrbios no sono e, 
consequentemente, acarreta um comprometimento na saúde da população. Relata, também, nesse estudo, interferências do ruido no comportamento da amostra, pois foi constatado que a maioria ( $71 \%$ ) raramente dorme com a janela aberta e que as pessoas que possuem seus quartos voltados para as ruas têm uma menor qualidade em bem-estar.

Renew (1993) desenvolveu um estudo, com objetivos similares ao de uma pesquisa realizada anteriormente, na mesma área, em 1975, com o intuito de obter uma análise comparativa de seus resultados referentes a alterações de comportamento da amostra. Nesse estudo a amostra convive com uma exposição a niveis de ruido entre 55 a $70 \mathrm{~dB}$ (A) Em seus resultados quanto à saúde, a maioria admitiu que o ruido pode afetar negativamente, havendo sido identificados efeitos, tais como: irritabilidade, estresse, preocupação e também asma e alta pressão sanguinea. Quanto à interferência do ruido, nas atividades e no comportamento diário, são colocadas como principais: a necessidade de fechamento das janelas, interferências em ouvir rádio e televisão e também em conversar e no sono.

Concluiu-se, portanto, haver realmente uma interferência do ruido na qualidade de vida da população e que esse problema sofreu um acréscimo na área de estudo, comparando-se com o estudo anterior realizado na mesma área .

Considerando que o conceito de saúde implica em uma garantia da qualidade de vida da população, inúmeros estudos vêm sendo realizados, buscando analisar, mais detalhadamente, a interferência do ruido urbano nas atividades comuns e diárias desenvolvidas pela população, para que possa ser identificado o comprometimento da qualidade de vida urbana.

Segundo pesquisa desenvolvida na cidade de Saragoça, Espanha, por Aguerri et al. (1993), a população identifica efeitos do ruido urbano presente naquela área. Foram identificadas doenças psiquicas como estresse, irritação $(33,3 \%)$; dificuldade em concentração $(26,7 \%)$; doenças fisicas $(11,1 \%)$; aumento de indisposição $(1,6 \%)$; qualquer efeito $(25,6 \%)$. Quanto às atividades que sofrem maior incômodo e interferências, foram identificadas: dormir $(54 \%)$; estudar $(49 \%)$; realização de trabalhos 
intelectuais (24\%); assistir à TV (23\%); conversação (20\%); realização de trabalhos manuais (11\%); audição de música (19\%) e de rádio $(5 \%)$.

Considerando outras variáveis do estudo concluiu-se, também, que pessoas mais jovens e intelectualmente mais desenvolvidas identificaram maior nivel de desconforto e são mais atentas aos problemas apontando dificuldade de concentração e incômodos psicológicos. Os demais, mais idosos e com menor nivel de escolaridade, apresentam um menor número de atitudes negativas e menor desconforto quanto ao ruido.

Ishiyama (1993) desenvolveu uma pesquisa em três áreas residenciais em Tokyo, onde se tinha uma exposição ao ruido entre 77.2 e $79 \mathrm{~dB}$. Ele buscou obter as reações da comunidade ao ruido do tráfego urbano. Verificou que o problema do ruido, entre os demais problemas ambientais (oferta de comércio, proximidade a escolas, transporte, segurança de pedestre, emissão de poluentes, lixo, paisagem urbano e relações de vizinhança) foi considerado o mais sério sendo seguido pela emissão de poluentes. O ruido é visto como um problema que afeta a qualidade de vida da comunidade em todas as áreas analisadas. Quanto à interferência do ruido nas atividades, os distúrbios do sono foram identificados como de maior comprometimento, sendo seguidos pelas interferências na conversação e audição de música. Foi ainda constatado que variáveis, tais como: idade, nível de sensibilidade ao ruido e tempo de residência interferem no nivel de incômodo.

Um estudo similar, buscando também analisar as reações da população ao ruido do tráfego urbano (49 a $76 \mathrm{~dB}(\mathrm{~A})$ na cidade de Modena, Itália), foi desenvolvido por Bertoni et al. (1993). Entre as atividades que foram identificadas pela amostra como de maior interferência, estão a dificuldade para ouvir música, a impossibilidade de manter as janelas abertas e de utilizar as varandas. Outras atividades foram também relatadas como comprometidas pelo ruido, tais como: a conversação e o descanso. Observou-se ainda que o número de pessoas incomodadas a um mesmo nivel de ruido é de 20 a $30 \%$ maior quando as janelas estão abertas sendo, portanto, o hábito de fechar as janelas uma alternativa para redução do ruido 
interno nas residências, podendo atuar como atenuante até uma exposição ao ruido de $90 \mathrm{~dB}(\mathrm{~A})$.

Analisando a discussão e os resultados de estudos até aqui apresentados, observa-se que a colocação do ruido do tráfego urbano como fonte direta e única de qualquer doença não é sustentada por muitos dos estudos até agora conduzidos. Não há estudo que relacione tempo de exposição a um determinado nivel de ruido de tráfego, no meio ambiente urbano, como causa de qualquer doença. As normas existentes referem-se a essa questão quando se trata da exposição ocupacional ao ruido, relacionando-o aos riscos à saúde humana.

Estudos demonstram que a perda ou redução da capacidade auditiva do homem, como efeito de exposição ao ruido, na maioria dos casos acontece quando se tem uma exposição a um nivel superior a $80 \mathrm{~dB}(A)$. $A$ exposição a um determinado nivel de ruído será sempre analisada relacionando-o com o tempo de exposição, de modo a determinar possibilidades de riscos de comprometer a audição. Essas situações são mais freqüentes, em ambientes de trabalhos.

Existem padrões para definir o nivel de permissividade ou niveis permissiveis para exposição ao ruído quando são discutidas as atividades ocupacionais. Elas são, segundo a Ocupacional Noise Exposures Regulations-OSHA: para $90 \mathrm{~dB}(\mathrm{~A})$ - tempo máximo de exposição = oito horas; $92 \mathrm{~dB}(\mathrm{~A})$ - tempo máximo de exposição $=6$ horas; $95 \mathrm{~dB}(\mathrm{~A})$ máximo de exposição $=4$ horas; $97 \mathrm{~dB}(\mathrm{~A})$ - tempo máximo de exposição = 3 horas ; $100 \mathrm{~dB}(A)$ - tempo máximo de exposição $=2$ horas; $102 \mathrm{~dB}(A)-$ tempo máximo de exposição $11 / 2$ horas; $105 \mathrm{~dB}(\mathrm{~A})$ - tempo máximo de exposição 1 hora; $110 \mathrm{~dB}(\mathrm{~A})$ - tempo máximo de exposição $1 / 2$ horas; 115 $\mathrm{dB}(\mathrm{A})$ - tempo máximo de exposição $1 / 4$ hora ou menos (OSHA, 1980) Quando a exposição ao ruido excede esses niveis, é obrigação do empregador implementar controles de engenharia e de administração definidos por lei.

Para as áreas residenciais, não existe qualquer nivel padrão definido. Existem sim recomendações sobre os niveis de ruido que devem acontecer 
nas áreas externas e internas das residências, como foram citadas no capitulo 5, de forma a não interferir no bem-estar das pessoas

Entretanto muitos dos estudos já discutidos detectaram efeitos diretos e indiretos que podem ser causados pelo ruído do tráfego urbano à população. Esses efeitos comprometem o bem estar da população e, consequentemente, podem vir a interagir, juntamente com outros fatores negativos que também sejam provenientes do meio ambiente urbano, podendo causar assim comprometimentos mais complexos da saúde humana.

Portanto serão considerados como fatores que podem gerar problemas de saúde os efeitos diretos e indiretos do ruído urbano descritos por Burns em 1969 e já confirmados por estudos recentes. Esses efeitos são: percepção do ruido, sensação de interferência em leituras e conversas, distúrbios do sono ou de descanso e distúrbios em atividades de trabalho ou lazer. Considerando que nesta pesquisa esses fatores são adotados como referência para avaliar o nivel de interferência do ruido do tráfego urbano na saúde, é de interesse discutir seus conceitos e especificidades que vêm, também, sendo analisados por vários estudos realizados nesta área.

O processo de percepção do ruido é relevante na realização de qualquer estudo. Ele precede a identificação do incômodo e da interferência na qualidade de vida urbana.

A percepção do ruido pela comunidade envolve a percepção de várias fontes de emissão ao mesmo tempo. Entretanto esse fato não impede a identificação de sons especificos que estejam presentes ao mesmo tempo (Berglund et Lindvall, 1995) .

A percepção encontra-se presente na realização de vários estudos que envolvem a avaliação de problemas pela própria comunidade. Ela atua nesses estudos como fonte $e$ instrumento decodificador de dados $e$ informações necessários para análises. .

Entre os efeitos do ruído, o primeiro a ser detectado é o incômodo. Ele vem sendo empregado em vários estudos como medida da reação da comunidade. Entretanto por ser uma variável subjetiva, discute-se se esta 
reação pode não ser apenas um incômodo e sim um outro sintoma desencadeado pelo ruido. As pessoas podem reagir com raiva, desapontamento, depressão, ansiedade e outros sentimentos à presença do ruido. Entretanto todos esses comportamentos são identificados como incômodos, dando uma margem muito ampla para o seu conceito. Existem estudos que levantam a discussão quanto ao assunto, argumentando que o termo incômodo não abrangeria e não cobriria todos os efeitos negativos produzidos pelo ruido (Job, 1993, Sutter ,1991).

$O$ incômodo gerado pelo ruido é identificado, na maioria dos estudos, como uma sensação de desprazer. Entretanto pode haver uma diversidade de reações que não sejam apenas uma sensação de desprazer.

A sensação e a tolerância ao incômodo variam de acordo com o tipo de atividade que o receptor esteja realizando (fala, comunicação, audição de rádio e TV, sono, etc.) O limite para que se inicie a sensação de incômodo para um ruido permanente e contínuo está na faixa de $50 \mathrm{~dB}$. Poucas pessoas são seriamente incomodadas durante o periodo do dia com níveis de ruido inferiores a $55 \mathrm{~dB}$. Recomenda-se que o nivel de ruido à noite seja de $5 \mathrm{~dB}$ a $10 \mathrm{~dB}$ inferior ao do periodo do dia (Sutter, 1991)

$A$ interferência do ruido na comunicação tem sido considerada com um dos impactos mais importantes. Estudos já realizados revelam que um nivel de conversa normal em residência é de aproximadamente de $55 \mathrm{~dB}(\mathrm{~A})$. A estimativa de inteligibilidade para as condições de reverberação tipicas encontradas nas salas residenciais, entre duas pessoas, em uma distancia maior de que um metro, é de $100 \%$ de clareza e compreensão quando o ruido de fundo for inferior a $45 \mathrm{~dB}(\mathrm{~A})$ em ambientes fechados, reduzindose para $99 \%$ quando o ruído de fundo for $55 \mathrm{~dB}(\mathrm{~A}), 95 \%$ quando for 64 $\mathrm{dB}(\mathrm{A})$ chegando a $0 \%$ quando o ruido de fundo atingir $75 \mathrm{~dB}(\mathrm{~A})$ (Berglund et Lindvall 1995, Sutter 1991).

A exposição ao ruido gera, também, efeitos no comportamento social das pessoas; entre eles observa-se, como já foi dito, a alteração de atitudes, tais como: a necessidade de fechamento de janelas, impedimento de ouvir rádio ou som, a não utilização de áreas abertas e outros. 
Agressividade, brigas, alteraçōes de humor e depressōes são também observados. São geralmente utilizados como indicadores desses efeitos: o movimento de mudanças de área de residências, admissões em hospitais, consumo de medicamentos (calmante, soniferos) e números de acidentes.

$O$ efeito negativo do ruído no sono tem sido um dos fatores mais citados nos estudos realizados. O sono é considerado um pré-requisito básico para a saúde fisiológica e mental. O comprometimento do sono, por exposição ao ruído, pode gerar efeitos negativos de grande relevância na saúde da população.

Estudos realizados pela EPA (1981) citado por Sutter (1991 p.30) identificam a necessidade de um nivel de ruido de $45 \mathrm{~dB}(\mathrm{~A})$, como média durante o dia, em ambientes fechados, o que consequentemente define a necessidade de uma média do nivel sonoro em $35 \mathrm{~dB}(\mathrm{~A})$, considerando a recomendação de redução de 5 a $10 \mathrm{~dB}(\mathrm{~A})$ durante o periodo noturno, para que não haja interferência no sono Diante de estudos realizados, recomenda-se, atualmente, que o nivel de ruido em bairros residenciais, no periodo da noite, seja mantido abaixo de $45 \mathrm{~dB}(\mathrm{~A})$.

A exposição ao ruido pode gerar efeitos primários e secundários. Entre os efeitos primários, são identificadas: dificuldade em iniciar o sono, alteração dos niveis de estágios do sono e interrupção do sono. Os efeitos secundários ocorrem posterior ao sono: durante o periodo de vigília $e$, também, ao longo do dia. Esses efeitos seriam reconhecidos pela constatação da má qualidade do sono, de um aumento do cansaço, do comprometimento do humor e do bem-estar e, ainda, através de efeitos adversos posteriores como dores de cabeça e redução da capacidade de ação e de trabalho (Berglund et Lindvall, 1995).

O tempo necessário para dormir depende da idade e das necessidades individuais de cada um. Os mais idosos tendem a ter um periodo de sono menor do que os demais.

Os efeitos da exposição ao ruído, no desempenho das pessoas, podem interferir no desenvolvimento de atividades complexas. Assim as atividades que requerem atenção continua para detalhamentos necessitam 
de uma atenção múltipla sensorial e de uma grande capacidade de memória, suscetiveis de serem altamente comprometidas.

A interferência na atividade de leitura tem sido muito discutida e é objeto de estudos de campo. Embora não tenha sido comprovada a interferência direta do ruido como causa de deficiência de leitura e compreensão, existem inúmeros estudos que mostram associações entre exposição crônica ao ruido de tráfego e deficiência na capacidade de leitura. Quanto à interferência do ruido de tráfego no nível de produtividade existem poucos estudos, não se tendo, portanto, conclusões sobre esta relação.

$O$ ruido atua também como um fator estressante e como tal pode causar alterações no organismo humano como, por exemplo, o aumento da pressão sanguínea, vaso construção, etc. Entretanto a magnitude desses efeitos é determinada em parte pela suscetibilidade individual, pelo tipo de vida e condições ambientais do meio em que vivem os individuos.

Os efeitos diretos e indiretos do tráfego urbano foram selecionados para o estudo nesta pesquisa, como indicadores de possiveis problemas de saúde na comunidade da área de estudo selecionada porque, embora nenhum desses efeitos seja identificado com uma doença, a presença de qualquer um deles implica no comprometimento da saúde $e$ consequentemente na qualidade ambiental urbana de qualquer comunidade. A escolha de uma doença especifica, como objeto de estudo, limitaria e restringiria em muito a abordagem do ruido como um problema urbano, distorcendo assim os objetivos definidos a serem alcançados neste trabalho.

Considerando a metodologia adotada para o desenvolvimento desta pesquisa, foi aplicado um questionário em uma amostra. Nas questões sobre a relação entre o ruido de tráfego e a saúde humana são abordados os efeitos negativos do ruido, buscando identificar sua existência, percepção, intensidade e frequência e futuras conseqüências que poderiam advir da presença do ruido de tráfego em áreas residenciais desta comunidade. 


\section{7 - RESULTADOS}

\section{1 - Estudo de Associações entre as Variáveis $\left(\chi^{2}, p\right)$}

\subsection{1- Perfil da População}

A amostra constituiu-se de 193 pessoas, sendo $123 \quad(63,7 \%)$ mulheres e $70(36,3 \%)$ homens. A distribuição etária descrita na Tabela 4 mostra uma idade média de 46,1 anos para os homens e de 46,4 anos para as mulheres. .

Tabela 4 - Distribuição da amostra por faixa etária

\begin{tabular}{ccc}
\hline Faixa Etária (anos) & Freqüência & Percentual \\
\hline$<40$ & 68 & $35,2 \%$ \\
$40-59$ & 83 & $43,0 \%$ \\
$60 \mathrm{e}+$ & 42 & $21,8 \%$ \\
\hline Total & 193 & $100,0 \%$ \\
\hline
\end{tabular}

Foram entrevistadas 81 pessoas na Asa Sul e 112 pessoas na Asa Norte de Brasilia. A Asa Norte é mais nova e concentra mais apartamentos por quadra do que a Asa Sul. Observa-se pelos dados apresentados na Tabela 5 que na Asa Norte há uma maior concentração de pessoas mais jovens do que na Asa Sul.

Tabela 5 - Distribuição da amostra por bairro e faixa etária

\begin{tabular}{|c|c|c|c|c|}
\hline \multirow{2}{*}{ Área } & \multicolumn{3}{|c|}{ Faixa Etária } & \multirow{2}{*}{ Total } \\
\hline & $<40$ & $40-59$ & $60 e>$ & \\
\hline Asa sul & $\begin{array}{c}22 \\
27,2 \%\end{array}$ & $\begin{array}{c}36 \\
44,4 \%\end{array}$ & $\begin{array}{c}23 \\
28,4 \%\end{array}$ & $\begin{array}{c}81 \\
42,0 \%\end{array}$ \\
\hline Asa Norte & $\begin{array}{c}46 \\
41,1 \%\end{array}$ & $\begin{array}{c}47 \\
42,0 \%\end{array}$ & $\begin{array}{c}19 \\
17,0 \%\end{array}$ & $\begin{array}{c}112 \\
58,0 \%\end{array}$ \\
\hline Total & $\begin{array}{c}68 \\
35.2 \%\end{array}$ & $\begin{array}{c}83 \\
43,0 \%\end{array}$ & $\begin{array}{c}42 \\
21.8 \%\end{array}$ & $\begin{array}{c}193 \\
100 \%\end{array}$ \\
\hline
\end{tabular}

A população entrevistada apresentou uma alta escolaridade pois $76 \%$ têm nivel superior conforme mostra a Tabela 6 Há um diferencial de 
escolaridade entre os sexos, cerca de $84 \%$ dos homens e $71 \%$ das mulheres tem nível superior .

Tabela 6 - Distribuição por nivel escolar

\begin{tabular}{lcc}
\hline Nivel Escolar & Freqüência & Percentual \\
\hline Primária & 2 & 1,0 \\
Secundária & 36 & 18,7 \\
Superior & 147 & 76,2 \\
Outra & 8 & 4,1 \\
\hline Total & 193 & 100,0 \\
\hline
\end{tabular}

A maior escolaridade encontra-se na faixa etária de 40-59 anos sendo menor para aqueles com mais de 60 anos, conforme dados apresentados na Tabela $7\left(\chi^{2}=13,54 ; d f=2 ; p=0,001\right)$

Tabela 7 - Distribuição por nivel escolar e faixa etária

\begin{tabular}{|c|c|c|c|c|}
\hline Nivel Escolar & $<40$ & $\begin{array}{c}\text { Faixa e } \\
40-59\end{array}$ & $60 \mathrm{e}>$ & Total \\
\hline $\begin{array}{l}\text { Sem Nivel } \\
\text { superior }\end{array}$ & $\begin{array}{l}17 \\
25,0 \%\end{array}$ & $\begin{array}{l}11 \\
13,3\end{array}$ & $\begin{array}{l}18 \\
42,9 \%\end{array}$ & 46 \\
\hline Superior & $\begin{array}{l}51 \\
75,0 \% \\
\end{array}$ & $\begin{array}{l}72 \\
86,7 \% \\
\end{array}$ & $\begin{array}{l}24 \\
57,1 \% \\
\end{array}$ & 147 \\
\hline Total & 68 & 83 & 42 & 193 \\
\hline
\end{tabular}

A Tabela 8 mostra que cerca da metade da amostra ( $49,7 \%)$ mora no mesmo apartamento há mais de 7 anos e $13 \%$ há quatro anos ou mais

Tabela 8 - Distribuição da amostra por tempo de residência na área

\begin{tabular}{ccc}
\hline Tempo residência & Frequência & Percentual \\
\hline$<1$ ano & 19 & $9,8 \%$ \\
$1-2$ anos & 20 & $10,4 \%$ \\
$2-4$ anos & 33 & $17,1 \%$ \\
$4-7$ anos & 25 & $13,0 \%$ \\
$>7$ anos & 96 & $49,7 \%$ \\
\hline Total & 193 & $100,0 \%$ \\
\hline
\end{tabular}

O maior tempo de residência está associado à idade, como mostra a Tabela 9, ou seja, os mais idosos moram há mais tempo no apartamento do que os mais jovens $\left(\chi^{2}=38,16\right.$; $\left.d f=8 ; p=0,00\right)$. Cerca de $85,7 \%$, têm idade 
superior ou igual a 60 anos e $26,5 \%$, com idade inferior a 40 anos. Grande parte da amostra reside no mesmo apartamento há mais de 15 anos.

Tabela 9 - Distribuição por tempo de residência na área e faixa etária.

\begin{tabular}{|c|c|c|c|c|c|}
\hline Faixa etária & \multicolumn{5}{|c|}{ Tempo de residência - anos - $n(\%)$} \\
\hline & $<1$ ano & $1-2$ & $2-4$ & 4-7 & $>7$ \\
\hline$<40$ anos & $11(16,2)$ & $11(16,2)$ & $17(25,0)$ & $11(16,2)$ & $18(26,5)$ \\
\hline $40-59$ & $7(8,4)$ & $8(9,6)$ & $13(15,7)$ & $13(15,7)$ & $42(50,6)$ \\
\hline $60 \mathrm{e}>$ & $1(2,4)$ & $1(2,4)$ & $1(7,1)$ & $1(2,4)$ & $16(85,7)$ \\
\hline Total & $19(9,8)$ & $20(10,4)$ & $33(17,1)$ & $25(13,0)$ & $96(49,7)$ \\
\hline
\end{tabular}

\subsection{2 - Perfil da residência}

A amostra foi selecionada de forma aleatória, sendo, portanto composta por pessoas residentes em todos os andares dos blocos selecionados, conforme mostra a Tabela 10.

Tabela 10 - Distribuição da amostra por andares de apartamento

\begin{tabular}{ccc}
\hline Andares & Freqüência & Percentual \\
\hline 1 & 34 & $17,5 \%$ \\
2 & 40 & $20,7 \%$ \\
3 & 37 & $19,2 \%$ \\
4 & 31 & $16,1 \%$ \\
5 & 26 & $13,5 \%$ \\
6 & 25 & $13,0 \%$ \\
\hline Total & 193 & $100,0 \%$ \\
\hline
\end{tabular}

O número de cômodos dos apartamentos varia de quatro a nove, excluindo as áreas destinadas a banheiros, sendo que a grande maioria deles tem de sete a oito cômodos.

Todos os apartamentos têm, no minimo, três cômodos com janelas voltadas diretamente para a via de tráfego considerada, o Eixo RW, e todos esses cômodos constituem-se de salas e quartos.

Quanto ao tamanho familiar da amostra a Tabela 11, mostra que $51,3 \%$ das familias são constituidas de quatro a seis pessoas e $44,6 \%$ de uma a três pessoas. 
Tabela 11 - Distribuição por número de pessoas por apartamento

\begin{tabular}{ccc}
\hline Número de pessoas/apartamento & Freqüência & Percentual \\
\hline 1 a 3 & 86 & $44,6 \%$ \\
4 a 6 & 99 & $51,3 \%$ \\
7 a 8 & 6 & $3,1 \%$ \\
9 e + & 2 & $1,0 \%$ \\
\hline Total & 193 & $100,0 \%$ \\
\hline
\end{tabular}

\subsubsection{Avaliação Ambiental da Área de Estudo}

A grande maioria ( $74 \%$ ) da amostra, tanto masculina como feminina gosta do lugar onde mora, enquanto uma pequena parte $(21 \%)$ não está satisfeita e gostaria de mudar-se, como pode ser visto pela Tabela 12.

Tabela 12 - Distribuição pela opção em gostar ou não da área onde reside

\begin{tabular}{lcc}
\hline Opções de respostas & Freqüência & Percentual (\%) \\
\hline Gosta & 142 & 73,6 \\
Indiferente & 10 & 5,2 \\
Gostaria de mudar & 32 & 16,6 \\
Mudaria rapidamente & 9 & 4,6 \\
\hline Total & 193 & 100,0 \\
& & \\
\hline
\end{tabular}

Embora o valor do qui-quadrado $\left(\chi^{2}\right)$ não seja aceito, pois a Tabela 13 apresenta valores inferiores a 5 ela revela uma tendência de que a aceitação do lugar está associado diretamente à idade ou seja, os mais velhos tenderiam a gostar mais do local onde vivem enquanto os mais jovens a rejeitá-lo.

Tabela 13 - Distribuição pela opção de gostar da área onde reside por faixa etária

\begin{tabular}{ccccc}
\hline \multirow{2}{*}{ Faixa Etária } & \multicolumn{3}{c}{ Opções de respostas } & \multirow{2}{*}{ Total } \\
\cline { 2 - 4 } & Gosta & Indiferente & Mudar & \\
\hline$<40$ & 42 & 4 & 22 & 68 \\
& $61,8 \%$ & $5,9 \%$ & $32,3 \%$ & $35,2 \%$ \\
$40-59$ & 62 & 5 & 16 & 83 \\
& $74,7 \%$ & $6,0 \%$ & $19,3 \%$ & $43,0 \%$ \\
$60 \mathrm{e}+$ & 38 & 1 & 3 & 42 \\
& $90.5 \%$ & $2,4 \%$ & $7,1 \%$ & $21,8 \%$ \\
\hline Total & 142 & 10 & 41 & 193 \\
\hline
\end{tabular}


O fato de gostar ou não do lugar onde mora também está associado ao tempo de residência no apartamento $\left(\chi^{2}=6,62 ; d f=1 ; p=0,01\right)$, ou seja, pessoas que moram há quatro anos ou mais gostam do apartamento mais do que quem mora há menos tempo, conforme os dados apresentados na Tabela 14.

Tabela 14 - Distribuição pela opinião de gostar ou não da área onde reside por tempo de residência (agrupados em $>4$ anos $\mathrm{e}=<4$ anos).

\begin{tabular}{cccc}
\hline \multirow{2}{*}{ Opções de respostas } & \multicolumn{2}{c}{ Tempo de residència (anos) } & Total \\
\cline { 2 - 4 } & $<4$ anos & 4 a mais & \\
\hline Gosta da área & 45 & 97 & 142 \\
Quer mudar & $67,2 \%$ & $83,6 \%$ & \\
& 22 & 19 & 41 \\
\hline Total & $32,8 \%$ & $16,4 \%$ & \\
\hline
\end{tabular}

"obs.: foram retirados 10 entrevistados que disseram ser indiferentes quanto a gostar ou não do lugar.

A caracteristica da área, mais apreciada pelos entrevistados, foi a boa localização do apartamento (56\%). Outras razões, também, foram citadas com menos frequência, como mostra a Tabela 15. Não houve variação estatisticamente significante entre este comportamento e as variáveis sexo e faixa etária.

Tabela 15 - Distribuição das características que mais gostam na área

\begin{tabular}{lcc}
\hline Características da área que mais gostam & Freqüência & $\%$ \\
\hline 1 - Boa localização & 108 & 56 \\
2 - Clima & 5 & 2,6 \\
3 - Vista & 15 & 7,8 \\
4 - Área Verde & 14 & 7,3 \\
5 - Oferta de comércio & 16 & 8,3 \\
6 - Ambiente da quadra & 13 & 6,7 \\
7 - Segurança & 2 & 1,0 \\
8 - Espaço urbano & 4 & 2,1 \\
9 - Transporte coletivo & 1 & 0,5 \\
12 - Qualidade do apartamento & 1 & 0,5 \\
13 - Outras & 9 & 0,5 \\
14 - A cidade & 5 & 2,7 \\
\hline \multicolumn{1}{c}{ Total } & 193 & 100,0 \\
\hline
\end{tabular}

Por outro lado, diante dos dados apresentados na Tabela 16, as características da cidade que menos agradam são mais diversificadas, sem 
preponderância de nenhuma de forma mais significativa: clima, barulho, violência e falta de segurança, dificuldade de entrosamento. A presença do ruido urbano na área é, portanto, considerada como a segunda característica que os entrevistados menos gostam. Aproximadamente um quinto da amostra não identificou qualquer aspecto que os desagradasse. Observa-se, ainda, que não há qualquer associação estatisticamente significante entre esta atitude e as variáveis sexo e faixa etária.

Tabela 16 - Distribuição da amostra segundo indicações das características que menos gostam na área.

\begin{tabular}{lcc}
\hline Caracteristicas da cidade que menos gostam & Freqüência & Percentual \\
\hline Falta de segurança & 12 & 6,2 \\
Barulho & 23 & 11,9 \\
Clima & 33 & 17,1 \\
Dificuldade de entrosamento & 16 & 8,3 \\
Transito & 12 & 6,2 \\
Violència & 14 & 7,3 \\
Outra & 46 & 23,8 \\
Não tem & 37 & 19,2 \\
\hline Total & 193 & 100,0 \\
\hline
\end{tabular}

Na Tabela 17, verifica-se que $64 \%$ da amostra classificam como boa qualidade do meio ambiente da cidade de Brasilia, e ainda, quase $80 \%$ o avaliam como bom ou ótimo. Os homens tendem a avaliar de forma mais favorável do que as mulheres o ambiente da cidade

As pessoas mais velhas avaliaram a cidade como boa ou ótima, com maior frequência do que os mais jovens; no entanto esta associação não se mostrou estatisticamente significante.

Tabela 17 - Distribuição segundo avaliação da qualidade ambiental da cidade

\begin{tabular}{lcc}
\hline Qualidade ambiental & Freqüencia & Percentual \\
\hline Ruim & 2 & $1,0 \%$ \\
Regular & 38 & $19,7 \%$ \\
Boa & 124 & $64,2 \%$ \\
Ótima & 29 & $15,0 \%$ \\
\hline Total & 193 & $100,0 \%$ \\
\hline
\end{tabular}


Os dados da Tabela 18 mostram que $90 \%$ dos homens consideram a qualidade ambiental da cidade ótima ou boa enquanto, uma porcentagem menor, $73 \%$ das mulheres são da mesma opinião. Portanto os homens qualificam melhor o meio ambiente da cidade do que as mulheres sendo esta associação estatisticamente significante $\left(\chi^{2}=7,6 ; d f=1 ; p=0,002\right)$

Tabela 18 - Distribuição da avaliação da qualidade ambiental da cidade por sexo.

\begin{tabular}{|c|c|c|c|}
\hline \multirow{2}{*}{ Avaliação } & \multicolumn{2}{|c|}{ Sexo } & \multirow{2}{*}{ Total } \\
\hline & Masculino $(\mathrm{N} / \%)$ & Feminino $(\mathrm{N} / \%)$ & \\
\hline Regular/ruim & $7 \quad(10,0)$ & $39(26,8)$ & 46 \\
\hline Boa/ótima & $63(90,0)$ & $90(73,2)$ & 153 \\
\hline Total & 70 & 123 & 193 \\
\hline
\end{tabular}

Os resultados obtidos na questão em que é solicitada uma avaliação da qualidade ambiental da área em que os entrevistados vivem são bem similares àqueles apresentados na questão anterior em que é solicitada uma avaliação da cidade. A qualidade ambiental da área onde moram é considerada boa ou ótima para cerca de dois terços (68\%) dos entrevistados conforme mostra a Tabela 19. Embora haja uma melhor avaliação da área pelos homens, assim como pelos mais velhos, estas associações não se mostraram significativas estatisticamente.

Tabela 19 - Distribuição da avaliação da qualidade ambiental da área onde vive.

\begin{tabular}{ccc}
\hline Qualidade ambiental & Freqüência & Percentual \\
\hline Ruim & 14 & $7,3 \%$ \\
Média & 48 & $24,8 \%$ \\
Boa & 100 & $51,8 \%$ \\
Ótima & 31 & $16,0 \chi^{2 \%}$ \\
\hline Total & 193 & $100,0 \%$ \\
\hline
\end{tabular}

Considerando os dados apresentados na Tabela 20, observa-se que o tempo de residência influi na avaliação da qualidade ambiental. As pessoas que moram há quatro anos ou mais avaliam o local onde vivem como bom ou ótimo, com maior frequência do que as que moram menos tempo no mesmo local sendo esta associação significativa estatisticamente $\left(\chi^{2}=6,75 ; d f=2 ; p=0,03\right)$ 
Tabela 20 - Distribuição da avaliação da qualidade ambiental da área por tempo de residência.

\begin{tabular}{lrcc}
\hline Qualidade ambiental & \multicolumn{2}{c}{ Tempo de residência } & \multirow{2}{*}{ Total } \\
\cline { 2 - 3 } \multicolumn{1}{c}{ onde vive } & $<4$ anos & 4 anos $\geq$ & \\
\hline Ruim & $9(64.3)$ & $5(35,7)$ & 14 \\
Média & $21(43,8)$ & $27(56,2)$ & 48 \\
Boa/Ótima & $42(32,1)$ & $89(67,9)$ & 131 \\
\hline Total & 72 & 121 & 193 \\
\hline
\end{tabular}

Os principais problemas ambientais na área de residência estão descritos na Tabela 21. Observa-se que o ruido é apontado como sendo o pior problema. A situação foi avaliada por mais da metade da amostra $(51,8 \%)$ como péssima . Além do ruído foram identificadas, ainda, como caracteristicas comprometedoras da área a qualidade do tráfego e a segurança.

Tabela 21 - Distribuição da avaliação de caracteristicas ambientais

\begin{tabular}{lcccc}
\hline Características & \multicolumn{4}{c}{ Avaliação } \\
\hline & Péssimo (\%) & Razoável (\%) & Bom (\%) & Ótimo (\%) \\
\hline Segurança & 10,9 & 50,3 & 35,7 & 3,1 \\
Oferta de transporte & 19,2 & 32,1 & 37,8 & 10,9 \\
Poluição & 9,8 & 32,1 & 44,6 & 13,5 \\
Ruido & 51,8 & 38,9 & 9,3 & 0,0 \\
Tráfego & 30,1 & 45,0 & 24,4 & 0,5 \\
Oferta a verdes & 2,6 & 11,9 & 48,7 & 36,8 \\
Oferta de espaço lazer & 16,1 & 33,7 & 35,2 & 15,0 \\
Limpeza urbana & 6,2 & 40,4 & 43,0 & 10,4 \\
\hline
\end{tabular}

A Tabela 22 mostra os fatores que foram considerados, pelos entrevistados, como prioritários na escolha de uma nova residência. Observa-se que a garantia de segurança é o principal item a ser considerado pela maioria das pessoas $(65 \%)$ e em segundo lugar a ausência de ruido/barulho (14\%) sendo seguidos pela garantia de uma boa qualidade de ar. Observa-se, ainda, que o ruido é uma caracteristica avaliada como péssima na área onde moram atualmente. 
Tabela 22 - Distribuição da amostra segundo prioridades adotadas em caso de escolha da área onde viriam morar

\begin{tabular}{lccc}
\hline \multicolumn{1}{c}{ Fatores } & \multicolumn{3}{c}{ Prioridades de escolha } \\
\hline & $1^{\mathrm{a}}(\%)$ & $2^{\mathbf{a}}(\%)$ & $3^{\mathrm{a}}(\%)$ \\
Segurança & 64,8 & 16,4 & 7,3 \\
Ausência de ruido & 13,5 & 21,2 & 14,5 \\
Oferta de transporte & 3,6 & 7,8 & 14,5 \\
Qualidade do ar & 4,1 & 18,7 & 21,2 \\
Bom tráfego & 2,6 & 7,8 & 10,4 \\
Áreas verdes & 6,2 & 9,3 & 11,9 \\
Espaço lazer & 2,1 & 7,8 & 6,7 \\
Limpeza urbana & 2,6 & 13,5 & 14,5 \\
\hline
\end{tabular}

\subsection{4 - Sensibilidade e Percepção do Ruido do Tráfego Urbano.}

Nas questões de números 9 a 21, foram obtidos dados para uma análise mais especifica quanto ao problema do ruido e para identificar desde o tempo de exposição até o nivel de percepção, a sensibilidade e o grau de incômodo provocado pelo ruido do tráfego urbano na amostra.

Os dados apresentados na Tabela 23 mostram que nos dias úteis a maioria da amostra (62,2\%) fica de 4 a 6 horas em casa. Esse tempo está, provavelmente, associado ao periodo de trabalho. As mulheres ficam mais em casa do que os homens $\left(\chi^{2}=6,94 ; d f=2 ; p=0,03\right)$, e as pessoas mais idosas mais tempo do que as mais jovens $\left(\chi^{2}=21,21\right.$; $d f=4 ; p=0,00$ ) como pode ser visto, respectivamente, nas Tabelas 24 e 25. A maior permanência dos mais idosos pode ser justificada pela presença, no grupo, de pessoas aposentadas

Tabela 23 - Distribuição por tempo de permanência em casa nos dias úteis

\begin{tabular}{ccc}
\hline $\begin{array}{c}\text { Tempo de permanência } \\
\text { diaria (horas) }\end{array}$ & Freqüência & Percentual \\
\hline $4-6$ & 120 & $62,2 \%$ \\
$7-10$ & 39 & $20,2 \%$ \\
$>10$ & 34 & $17,6 \%$ \\
\hline Total & 193 & $100.0 \%$ \\
\hline
\end{tabular}


Tabela 24 - Distribuição segundo o tempo de permanência em casa nos dias úteis e a variável sexo

\begin{tabular}{cccc}
\hline \multirow{2}{*}{$\begin{array}{c}\text { Tempo de } \\
\text { permanência (horas) }\end{array}$} & Masculino & Feminino & Total \\
\hline $4-6$ & 52 & 68 & 120 \\
& $74,3 \%$ & $55,3 \%$ & $62,2 \%$ \\
$7-10$ & 9 & 30 & 39 \\
& $12,9 \%$ & $24,4 \%$ & $20,2 \%$ \\
$>10$ & 9 & 25 & 34 \\
& $12,8 \%$ & $20,3 \%$ & $17,6 \%$ \\
\hline Total & 70 & 123 & 193 \\
\hline
\end{tabular}

Tabela 25 - Distribuição segundo tempo de permanência em casa (horas) nos dias úteis por faixa etária

\begin{tabular}{ccccc}
\hline \multirow{2}{*}{$\begin{array}{c}\text { Tempo de } \\
\text { permanência }\end{array}$} & \multicolumn{3}{c}{ Faixa Etária (anos) } & \multirow{2}{*}{ Total } \\
\cline { 2 - 4 } (horas) & $<40$ & $40-59$ & $60 \geq$ & \\
\hline $4-6$ & 50 & 56 & 14 & 120 \\
& $73,5 \%$ & $67,5 \%$ & $33,3 \%$ & \\
$7-10$ & 12 & 12 & 15 & 39 \\
& $17,6 \%$ & $14,5 \%$ & $35,7 \%$ & \\
$>10$ & 6 & 15 & 13 & 34 \\
& $8.8 \%$ & $18,1 \%$ & $31 \%$ & \\
\hline Total & 68 & 83 & 42 & 193 \\
\hline
\end{tabular}

Observa-se, através dos resultados da Tabela 26, que as pessoas permanecem mais em casa durante o final de semana.

A análise entre o tempo de ficar em casa nos finais de semana e as variáveis sexo e faixa etária, embora apresentem diferenças similares às que foram encontradas com a variável tempo de ficar em casa durante a semana, não são estatisticamente significantes.

Tabela 26 - Distribuição do tempo de permanência em casa no final de semana

\begin{tabular}{ccc}
\hline Tempo de permanència (horas) & Freqüência & Percentual \\
\hline $4-6$ & 46 & $23,8 \%$ \\
$7-10$ & 39 & $20,2 \%$ \\
$>10$ & 108 & $56,0 \%$ \\
\hline Total & 193 & $100,0 \%$ \\
\hline
\end{tabular}


Na Tabela 27 , verifica-se que cerca de $41 \%$ dos entrevistados se auto classificaram como tendo uma alta sensibilidade ao barulho/ruido. A amostra não demonstra diferenças de comportamento estatisticamente significantes tanto entre os sexos como também entre as faixas etárias

Tabela 27 - Distribuição segundo nivel de sensibilidade ao ruido

\begin{tabular}{ccc}
\hline Nivel de sensibilidade ao ruido & Frequência & Percentual \\
\hline Alta & 79 & $40,9 \%$ \\
Média & 88 & $45,6 \%$ \\
Baixa & 26 & $13,5 \%$ \\
\hline Total & 193 & $100,0 \%$ \\
\hline
\end{tabular}

Através dos dados da Tabela 28, observa-se que na avaliação do próprio apartamento, quanto ao nivel de barulho, mais de dois terços da amostra (66\%) classificaram-no como barulhento e muito barulhento.

Tabela 28 - Distribuição segundo avaliação do próprio apartamento quanto ao nivel de barulho.

\begin{tabular}{lcc}
\hline Avaliação do apartamento & Freqüencia & Percentual \\
\hline Muito Barulho & 69 & $35,8 \%$ \\
Barulhento & 59 & $30,6 \%$ \\
Moderadol silencioso & 65 & $33,6 \%$ \\
Total & 193 & $100,0 \%$ \\
\hline
\end{tabular}

As mulheres, mais do que os homens, classificam seus apartamentos, conforme mostra a Tabela 29, como muito barulhentos e barulhento $\left(\chi^{2}=\right.$ 9,81; $d f=2 ; p=0,007$ ).

Tabela 29 - Distribuição da amostra segundo avaliação do próprio apartamento quanto ao nivel de barulho, por sexo.

\begin{tabular}{cccc}
\hline \multirow{2}{*}{ Avaliação do apartamento } & \multicolumn{3}{c}{ Sexo } \\
\cline { 2 - 3 } & Masculino & Feminino & Total \\
\hline Muito barulho & 15 & 54 & 69 \\
& $(21,5) \%$ & $43,9 \%$ & $35,8 \%$ \\
Barulhento & 26 & 33 & 59 \\
& $37,1 \%$ & $26,8 \%$ & $30,6 \%$ \\
Moderado & 29 & 36 & 65 \\
& $41,4 \%$ & $29,3 \%$ & $33,6 \%$ \\
\hline Total & 70 & 123 & 193 \\
\hline
\end{tabular}


A Tabela 30 mostra que os mais idosos (60 anos ou mais) avaliam seu apartamento como "muito barulhento com menos frequência do que os de faixas etárias inferiores agrupadas," $\left(\chi^{2}=4,79 ; \mathrm{df}=1 ; p=0,03\right)$.

Tabela 30 - Distribuição segundo avaliação do apartamento quanto ao nível de barulho por faixa etária com apenas três alternativas de respostas.

\begin{tabular}{|c|c|c|c|}
\hline \multirow{2}{*}{ Avaliação do apartamento } & \multicolumn{2}{|c|}{ Faixa Etária } & \multirow{2}{*}{ Total } \\
\hline & $<60$ & $60 \mathrm{e}>$ & \\
\hline Muito barulhento & $\begin{array}{c}60 \\
39,7 \%\end{array}$ & $\begin{array}{c}9 \\
21,4 \%\end{array}$ & $\begin{array}{c}69 \\
35,8 \%\end{array}$ \\
\hline Moderado/barulhento/silencioso & $\begin{array}{c}91 \\
60,3 \% \\
\end{array}$ & $\begin{array}{c}33 \\
78,6 \% \\
\end{array}$ & $\begin{array}{r}124 \\
64,2 \% \\
\end{array}$ \\
\hline Total & $\begin{array}{c}151 \\
78,2 \%\end{array}$ & $\begin{array}{c}42 \\
21,8 \%\end{array}$ & 193 \\
\hline
\end{tabular}

Analisando-se a relação entre a identificação do nivel de barulho nos apartamentos e os bairros, verifica-se, através da Tabela 31, que o bairro da Asa Sul é avaliado pelos seus moradores com maior freqüência como "barulhento" e "muito barulhento" do que pelos moradores da Asa Norte $\left(\chi^{2}=\right.$ 9,33; $\mathrm{df}=4 ; \mathbf{p}=\mathbf{0 , 0 0 9}$ ). Este comportamento, pode ser justificado pelo fato de que os eixos rodoviários da Asa Sul tem um volume de tráfego de veículos/dia, como foi identificado em capitulo anterior, bem superior aos eixos rodoviários norte.

Tabela 31 - Distribuição da amostra segundo avaliação do próprio apartamento quanto ao nivel de barulho por bairro.

\begin{tabular}{cccc}
\hline \multirow{2}{*}{ Avaliação do apartamento } & \multicolumn{3}{c}{ Bairro } \\
\cline { 2 - 4 } & Asa Sul & Asa Norte & Total \\
\hline Muito barulho & 31 & 38 & 69 \\
& $38.3 \%$ & $33.9 \%$ & $35.8 \%$ \\
Barulhento & 32. & 27 & 59 \\
& $39,5 \%$ & $24,1 \%$ & $30.6 \%$ \\
Moderado/Silencioso & 18 & 47 & 65 \\
& $22,2 \%$ & $42,0 \%$ & $33,6 \%$ \\
\hline Total & 81 & 112 & 193 \\
& $42,0 \%$ & $58,0 \%$ & \\
\hline
\end{tabular}


A intensidade do barulho do tráfego assusta uma parcela importante da população (39\%) conforme mostra a Tabela 32.

Tabela 32 - Distribuição segundo as pessoas que se assustam com o barulho.

\begin{tabular}{ccc}
\hline Assusta-se com o barulho & Freqüência & Percentual \\
\hline Sim & 76 & $39,4 \%$ \\
Não & 117 & $60,6 \%$ \\
\hline Total & 193 & $100,0 \%$ \\
\hline
\end{tabular}

Considerando os resultados apresentados na Tabela 33, o efeito nas mulheres ( $46,3 \%$ ) é maior do que nos homens $(27,1 \%)$, sendo esta uma associação estatisticamente significante $\left(\chi^{2}=6,89 ; d f=1 ; p=0,009\right)$.

Quanto à faixa etária, as diferenças encontradas nos resultados não apresentam significância estatística.

Tabela 33 - Distribuição das pessoas que se assustam com o barulho e a variável sexo

\begin{tabular}{cccc}
\hline \multirow{2}{*}{ Assusta-se } & \multicolumn{2}{c}{ Sexo } & \multirow{2}{*}{ Total } \\
\cline { 2 - 3 } & Masculino & Feminino & \\
\hline Sim & 19 & 57 & 7.6 \\
& $27,1 \%$ & $46,3 \%$ & \\
Não & 51 & 66 & 117 \\
& $72,9 \%$ & $53,0 \%$ & \\
\hline Total & 70 & 123 & 193 \\
\hline
\end{tabular}

Os dados da Tabela 34 mostram que o barulho do tráfego faz com que mais da metade das pessoas (56\%) fechem as janelas ao longo do dia. Entretanto não há diferenças de comportamento entre homens e mulheres. 
Tabela 34 - Distribuição segundo o costume de fechar as janelas ao longo do dia.

\begin{tabular}{ccc}
\hline Janelas Fechadas & Freqüencia & Percentual \\
\hline Sim & 108 & $56,0 \%$ \\
Não & 85 & $44,0 \%$ \\
\hline Total & 193 & $100,0 \%$ \\
\hline
\end{tabular}

A Tabela 35 indica uma tendência de que as pessoas com sessenta anos ou mais fecham as janelas com menos frequência, embora esse resultado não seja estatisticamente significante $\left(\chi^{2}=3,74 ; d f=1 ; p=0,053\right)$.

Tabela 35 - Distribuição do costume da amostra de fechar as janelas ao longo do dia por faixa etária agrupadas em $<60$ e $60=>$.

\begin{tabular}{cccc}
\hline \multirow{2}{*}{ Janelas Fechadas } & \multicolumn{2}{c}{ Faixa Etária } & \multirow{2}{*}{ Total } \\
\cline { 2 - 3 } & $<60$ & $60>=$ & \\
\hline Sim & 90 & 18 & 108 \\
& $59,6 \%$ & $42,9 \%$ & $56,0 \%$ \\
Não & 61 & 24 & 85 \\
& $40,4 \%$ & $57,1 \%$ & $44,0 \%$ \\
\hline Total & 151 & 42 & 193 \\
& $78,2 \%$ & $21,8 \%$ & \\
\hline
\end{tabular}

Na Tabela 36 observa-se que a maioria da amostra $(88,6 \%)$ sente-se incomodada pelo barulho do tráfego, não havendo entretanto diferenças de comportamento entre homens e mulheres.

Tabela 36 - Distribuição da amostra segundo identificação de incômodo provocado pelo barulho.

\begin{tabular}{ccc}
\hline Incomoda & Freqüência & Percentual \\
\hline Sim & 171 & $88,6 \%$ \\
Não & 22 & $11,4 \%$ \\
\hline Total & 193 & $100.0 \%$ \\
\hline
\end{tabular}


Através da Tabela 37, verifica-se que ocorrem diferenças de comportamento por faixa etária, ou seja, os mais velhos, com idade igual ou superior a sessenta anos, queixam-se menos de incômodo pelo barulho do que os de idade inferior, sendo esta associação estatisticamente significante $\left(\chi^{2}=16,27 ; d f=2 ; p=0,000\right)$.

Tabela 37 - Distribuição segundo identificação de incômodo provocado pelo barulho por faixa etária.

\begin{tabular}{ccccc}
\hline & \multicolumn{3}{c}{ Faixa Etária } & \multirow{2}{*}{ Total } \\
\cline { 2 - 4 } Incomoda & $<40$ & $40-59$ & $60>=$ & \\
\hline Sim & 65 & 76 & 30 & 171 \\
& $95,6 \%$ & $91,6 \%$ & $71,4 \%$ & 22 \\
Não & 3 & 7 & 12 & \\
\hline Total & $4,4 \%$ & $8,4 \%$ & $28,6 \%$ & 193 \\
\hline
\end{tabular}

A Tabela 38 revela que o nivel de incômodo provocado pelo barulho é identificado por mais de um terço da amostra como alto e, ainda, $36 \%$ o qualifica de médio, o que demonstra que a grande maioria dos entrevistados realmente convive com uma situação desagradável quanto ao problema do ruido.

Tabela 38 - Distribuição segundo identificação do nivel de incômodo provocado pelo barulho.

\begin{tabular}{ccc}
\hline Nivel de incômodo & Freqüência & Percentual \\
\hline Nenhum & 22 & $11,4 \%$ \\
Pouco & 30 & $15,5 \%$ \\
Médio & 71 & $36,8 \%$ \\
Muito & 70 & $36,3 \%$ \\
\hline Total & 193 & $100,0 \%$ \\
\hline
\end{tabular}


Através da Tabela 39 observa-se que as mulheres sofrem maior incômodo do que os homens $\left(\chi^{2}=11,9 ;\right.$ df $\left.=2 ; p=0,002\right)$ sendo este comportamento estatisticamente significante.

Tabela 39 - Distribuição da amostra segundo identificação do nivel de incômodo provocado pelo barulho por sexo.

\begin{tabular}{|c|c|c|c|}
\hline \multirow{2}{*}{ Incomoda/barulho } & \multicolumn{2}{|c|}{ Sexo } & \multirow{2}{*}{ Total } \\
\hline & Masculino & Feminino & \\
\hline Pouco / Nenhum & $\begin{array}{c}20 \\
28,6 \%\end{array}$ & $\begin{array}{c}32 \\
26.0 \%\end{array}$ & $\begin{array}{c}52 \\
26.9 \%\end{array}$ \\
\hline Médio & 35 & 36 & $\begin{array}{c}71 \\
368 \%\end{array}$ \\
\hline Muito & $\begin{array}{c}15 \\
21,4 \% \\
\end{array}$ & $\begin{array}{c}55 \\
44,7 \% \\
\end{array}$ & $\begin{array}{c}70 \\
36.3 \%\end{array}$ \\
\hline Total & $\begin{array}{c}70 \\
36.3 \%\end{array}$ & $\begin{array}{c}123 \\
63.7 \%\end{array}$ & 193 \\
\hline
\end{tabular}

Os mais velhos incomodam-se menos com o ruido do que os de menor faixa etária $\left(\chi^{2}=11,69 ; d f=4 ; p=0,02\right)$, como mostra a Tabela 40 .

Tabela 40 - Distribuição da amostra segundo identificação do nivel de incômodo provocado pelo barulho por faixa etária.

\begin{tabular}{ccccc}
\hline \multirow{2}{*}{$\begin{array}{c}\text { Nivel de } \\
\text { Incômodo }\end{array}$} & \multicolumn{5}{c}{ Faixa Etária } \\
\cline { 2 - 5 } & $<40$ & $40-59$ & $60>=$ & Total \\
\hline Pouco/Nenhum & 14 & 18 & 20 & 52 \\
& $20,6 \%$ & $21,7 \%$ & $47,6 \%$ & $26,9 \%$ \\
Medio/ Muito & 27 & 33 & 11 & 71 \\
Muito & $39,7 \%$ & $39,7 \%$ & $26,2 \%$ & $36,3 \%$ \\
& 27 & 32 & 11 & 70 \\
\hline Total & $39,7 \%$ & $38,6 \%$ & $26,2 \%$ & \\
\hline
\end{tabular}

Esta associação torna-se mais evidente quando os intervalos da faixa etária, entre idades inferiores a sessenta anos ou igual e superior a sessenta, são agrupados $\left(\chi^{2}=11,6 ; d f=1 ; p=0,000\right)$, como na Tabela 41 . 
Tabela 41 - Distribuição da amostra segundo identificação do nivel de incômodo provocado pelo barulho por faixa etária, agrupandoa em intervalos de idade $<60$ e $\geq 60$ anos.

\begin{tabular}{lccc}
\hline \multirow{2}{*}{ Nivel de Incômodo } & \multicolumn{2}{c}{ Faixa Etária } & \multirow{2}{*}{ Total } \\
\cline { 2 - 3 } & $<60$ & $60 \mathrm{e}\rangle$ & 52 \\
Nenhum/ Pouco & 32 & 20 & $26,9 \%$ \\
& $21,2 \%$ & $47,6 \%$ & \\
Médio/Muito & 119 & 22 & 141 \\
& $78,8 \%$ & $52,4 \%$ & $73,1 \%$ \\
\hline Total & 151 & 42 & 193 \\
& $78,2 \%$ & $21,8 \%$ & $100 \%$ \\
\hline
\end{tabular}

Diante dos dados apresentados na Tabela 42, verifica-se que a maioria da amostra (51\%) é mais incomodada pelo barulho durante a semana e que mais de $21 \%$ revelam-se incomodados todos os dias, incluindo os finais de semana.

Tabela 42 - Distribuição da amostra segundo identificação dos dias de maior incômodo durante a semana.

\begin{tabular}{lcc}
\hline Dias da semana de maior incômodo & Freqüência & Percentual \\
& & \\
\hline Segunda - sexta feira & 99 & $51,3 \%$ \\
Finais de semana & 25 & $13,0 \%$ \\
Todos os dias & 44 & $22,8 \%$ \\
Nenhum & 25 & $13,0 \%$ \\
\hline Total & 193 & $100,0 \%$ \\
\hline
\end{tabular}

Considerando os dados da Tabela 43, observa-se que os periodos em que as pessoas se sentem mais incomodadas pelo ruido do tráfego é, primeiramente, no periodo noturno, sendo seguido pelo periodo da manhã e posteriormente pelo período que compreende o final da tarde. Esse fato talvez seja explicado pelos periodos de pico no tráfego, que ocorrem nesses horários, e, também, pelo fato de que as pessoas que trabalham fora se encontram em casa nesses horários. 
Tabela 43 - Distribuição segundo identificação dos periodos de maior incômodo ao longo do dia.

\begin{tabular}{lc}
\hline Periodos de maior incômodo & Percentual \\
\hline Manhã & 21,2 \\
Almoço & 9,3 \\
Fim de tarde & 18,1 \\
Noite & 27,5 \\
Todos & 9,3 \\
Nenhum & 11,5 \\
\hline
\end{tabular}

A Tabela 44 mostra que mais de dois terços da amostra $(68,9 \%)$ já estão acostumados com o barulho.

Tabela 44 - Distribuição segundo a referência de estar acostumado com o ruido do tráfego

\begin{tabular}{ccc}
\hline Costume & Freqüência & Percentual \\
\hline Sim & 133 & $68,9 \%$ \\
Não & 60 & $31,1 \%$ \\
\hline Total & 193 & $100,0 \%$ \\
\hline
\end{tabular}

Os homens parecem acostumar-se com o barulho mais facilmente do que as mulheres, sendo a associação estatisticamente significante $\left(\chi^{2}=\right.$ $\mathbf{4 , 7 8} ; \mathrm{df}=1 ; \quad \mathbf{p}=\mathbf{0 , 0 3}$ ), conforme mostram os resultados na Tabela 45 $(p=0,03)$. Quanto à avaliação com a variável faixa etária, não foram encontradas diferenças de comportamento entre os grupos.

Tabela 45 - Distribuição segundo o costume com o ruido do tráfego, por sexo

\begin{tabular}{cccc}
\hline \multirow{2}{*}{ Costume } & \multicolumn{3}{c}{ Sexo } \\
\cline { 2 - 3 } & Masculino & Fetal \\
\cline { 2 - 3 } Sim & 55 & 78 & 133 \\
& $78,6 \%$ & $63,4 \%$ & \\
Não & 15 & 45 & 60 \\
& $21,4 \%$ & $36,6 \%$ & \\
\hline Total & $70(36,3 \%)$ & $123(63,7 \%)$ & 193 \\
\hline
\end{tabular}




\subsection{5 - Efeitos do Ruido de Tráfego.}

As questões de números vinte e um a trinta e um foram elaboradas para analisar a interferência e os efeitos do ruído no bem-estar e na saúde da população. Houve, nesta etapa, a preocupação em identificar que tipos de atividades diárias estariam sendo comprometidas e em que intensidade, buscando assim dimensionar os impactos que estariam sendo gerados pelo ruido do tráfego urbano na qualidade de vida da população.

Os resultados apresentados na Tabela 46 demonstram que $75 \%$ das pessoas que compõem a amostra declararam que o barulho do tráfego interfere, ou melhor, compromete a realização de pelo menos uma das atividades diárias, como: dormir, assistir TV, ouvir música, conversar, estudar ou trabalhar.

Tabela 46 - Distribuição segundo identificação de interferência do ruido em atividades diárias

\begin{tabular}{ccc}
\hline Interfere em Atividades & Frequência & Percentual \\
& & \\
\hline Sim & 144 & $74,6 \%$ \\
Não & 49 & $25,4 \%$ \\
\hline Total & 193 & $100,0 \%$ \\
\hline
\end{tabular}

A Tabela 47 mostra os resultados da questão em que foi solicitada a identificação do comprometimento das atividades pelo ruído do tráfego. $26,9 \%$ identificaram o sono, $25,8 \%$ identificaram todas as atividades e 25,5 não identificaram qualquer interferência e os demais outras atividades. Observa-se, pelos resultados, que pelo menos $74,5 \%$ da amostra são incomodados em algumas das atividades citadas, e dessas, 25\% são incomodados em todas elas. Mulheres identificam muito mais a interferência do ruido na realização de atividades do que os homens; entretanto não há associação estatisticamente significativo entre as variáveis. 
Tabela 47 - Distribuição segundo opção de atividades que sofrem maior interferência pelo ruido de tráfego.

\begin{tabular}{lcc}
\hline \multicolumn{1}{c}{ Atividades } & Freqüência & Percentual \\
\hline Dormir & 52 & $26,9 \%$ \\
Assistir TV & 18 & $9,4 \%$ \\
Ouvir som & 7 & $3,6 \%$ \\
Conversar & 5 & $2,6 \%$ \\
Estudar & 8 & $4,1 \%$ \\
Trabalhar & 1 & $0,5 \%$ \\
Todas atividades & 50 & $25,8 \%$ \\
Nenhuma & 49 & $25,5 \%$ \\
Outras & 3 & $1,6 \%$ \\
\hline Total & 193 & $100,0 \%$ \\
\hline
\end{tabular}

Quanto às atividades de ouvir música, rádio ou TV, conforme mostra a Tabela 48 , para $31 \%$ da amostra sempre ocorre interferência, para $38 \%$ apenas algumas vezes e os demais revelaram não serem incomodados pelo barulho na realização dessas atividades.

Tabela 48 - Distribuição segundo a identificação de interferência do ruido de tráfego na atividade de ouvir som, radio e TV.

\begin{tabular}{ccc}
\hline $\begin{array}{c}\text { Interferência em ouvir música ou } \\
\text { rádio }\end{array}$ & Frequência & Percentual \\
\hline Sempre & 59 & $30,6 \%$ \\
Algumas vezes & 73 & $37,8 \%$ \\
Nunca & 61 & $31,6 \%$ \\
\hline Total & 193 & $100,0 \%$ \\
\hline
\end{tabular}

Na Tabela 49, verifica-se que os dados revelam que o barulho do tráfego afeta mais às mulheres do que aos homens $\left(\chi^{2}=\mathbf{8 , 4 1} ; \mathrm{df}=2 ; \mathbf{p}=\right.$ $0,014)$, nesta atividade, sendo estatisticamente significante esta associação.

Quanto à faixa etária não se observa comportamento diferenciado entre os grupos, não havendo portanto qualquer associação estatisticamente significativo 
Tabela 49 - Distribuição segundo a identificação de interferência do ruido de tráfego na atividade de ouvir som, rádio e $T \mathrm{~V}$, por sexo.

\begin{tabular}{cccc}
\hline \multirow{2}{*}{$\begin{array}{c}\text { Interferência em } \\
\text { ouvir som ou radio }\end{array}$} & \multicolumn{2}{c}{ Sexo } & Total \\
\cline { 2 - 3 } & Masculino & Feminino & \\
\hline Sempre & 14 & 45 & 59 \\
& $20,0 \%$ & $36,6 \%$ & $30,6 \%$ \\
Algumas vezes & 35 & 38 & 73 \\
& $50,0 \%$ & $30,9 \%$ & $37,8 \%$ \\
Nunca & 21 & 40 & 61 \\
& $30,0 \%$ & $32,5 \%$ & $31,6 \%$ \\
\hline Total & $70(36,3 \%)$ & $123(63,7)$ & 193 \\
\hline
\end{tabular}

Analisando os resultados nas Tabelas 50,51, 52, constata-se que o barulho do tráfego atinge mais seriamente a atividade de dormir. Observa-se ainda que as demais atividades, como: ler, estudar ou falar ao telefone, também são comprometidas considerando que o barulho afeta mais da metade da amostra em todas as atividades.

Os resultados da análise entre a interferência do barulho nas atividades ler, falar ao telefone e dormir, com as variáveis sexo e faixa etária nāo revelam qualquer associaçāo estatisticamente significante.

Tabela 50 - Distribuição segundo a identificação de interferência do ruido de tráfego na atividade de leitura.

\begin{tabular}{ccc}
\hline Ler & Frequência & Percentual \\
\hline Sim & 109 & $56,5 \%$ \\
Não & 84 & $43,5 \%$ \\
\hline Total & 193 & $100,0 \%$ \\
\hline
\end{tabular}

Tabela 51 - Distribuição segundo a identificação de interferência do ruido de tráfego na atividade de falar.

\begin{tabular}{ccc}
\hline Falar & Frequência & Percentual \\
\hline Sim & 85 & $44,0 \%$ \\
Não & 108 & $56,0 \%$ \\
\hline Total & 193 & $100.0 \%$ \\
\hline
\end{tabular}


Tabela 52 - Distribuição da amostra segundo a identificação de interferência do ruido de tráfego na atividade de dormir.

\begin{tabular}{ccc}
\hline Dormir & Freqüência & Percentual \\
\hline Sim & 119 & $61,7 \%$ \\
Não & 74 & $38,3 \%$ \\
\hline Total & 193 & $100,0 \%$ \\
\hline
\end{tabular}

Entretanto, observa-se que quando se agrupam os intervalos da faixa etária entre idades inferiores a sessenta anos e iguais ou maiores do que sessenta anos, como apresentado na Tabela 53, analisando-os com a atividade de leitura, encontra-se uma distribuição estatisticamente significante, mostrando que o ruido afeta mais as pessoas de idade inferior a sessenta anos do que os mais velhos $\left(\chi^{2}=\mathbf{0 . 4 , 0 5} ; \mathrm{df}=2 ; p=0,04\right)$

Tabela 53 - Distribuição segundo a identificação de interferência do ruido de tráfego na atividade de leitura por faixa etária.

\begin{tabular}{cccc}
\hline Leitura & \multicolumn{2}{c}{ Faixa Etária } & \multirow{2}{*}{ Total } \\
\cline { 2 - 3 } & $<60$ & $60 \mathrm{e}+$ & \\
\hline Sim & 91 & 18 & 109 \\
& $60,3 \%$ & $42,9 \%$ & $56,5 \%$ \\
Não & 60 & 24 & 84 \\
& $39,7 \%$ & $57,1 \%$ & $43,5 \%$ \\
\hline Total & 151 & 42 & 193 \\
& $78.2 \%$ & $21,8 \%$ & \\
\hline
\end{tabular}

Na questão, em que foi perguntado se o barulho do tráfego já teria gerado algum problema de saúde ao entrevistado, procurou-se, primeiramente, esclarecer que a presença do problema compreenderia desde provocar um estado de nervosismo e/ou estresse até uma redução da própria audiçāo.

Observando-se os resultados apresentados na Tabela 54 verifica-se que cerca de $28 \%$ das pessoas acreditam que o barulho causa algum mal à sua saúde. Esse não foi, portanto, um comportamento da maioria da amostra. 
Tabela 54 - Distribuição segundo a identificação de danos causados pelo ruido do tráfego à saúde do entrevistado.

\begin{tabular}{ccc}
\hline $\begin{array}{c}\text { Barulho prejudica a } \\
\text { Sua saúde }\end{array}$ & Freqüência & Percentual \\
\hline Sim & 53 & $27,5 \%$ \\
Não & 140 & $72,5 \%$ \\
\hline Total & 193 & $100,0 \%$ \\
\hline
\end{tabular}

A Tabela 55 revela que as mulheres identificam o problema de modo mais freqüente do que os homens $\left(\chi^{2}=7.61 ; d f=1 ; p=0,005\right)$.

Tabela 55 - Distribuição segundo os danos causados pelo ruído do tráfego à saúde do entrevistado por sexo.

\begin{tabular}{cccc}
\hline \multirow{2}{*}{$\begin{array}{c}\text { Barulho prejudica } \\
\text { a sua saúde }\end{array}$} & \multicolumn{3}{c}{ Sexo } \\
\cline { 2 - 3 } Total \\
\cline { 2 - 3 } Sim & Masculino & Feminino & \\
& 11 & 42 & 53 \\
Não & $15,7 \%$ & $34,1 \%$ & $27,5 \%$ \\
& 59 & 81 & 140 \\
Total & $84,3 \%$ & $65,9 \%$ & $72,5 \%$ \\
\hline
\end{tabular}

Embora não sejam estatisticamente significantes $\left(\chi^{2}=1,17 \mathrm{df}=2 ; p=\right.$ 0,56) os resultados da Tabela 56 indicam uma tendência de que as pessoas mais jovens têm uma maior percepção do problema com a saúde, causado pelo ruido de tráfego.

Tabela 56 - Distribuição segundo os danos causados pelo ruido do tráfego à saúde do entrevistado por faixa etária

\begin{tabular}{ccccc}
\hline $\begin{array}{c}\text { Barulho } \\
\text { prejudica a }\end{array}$ & \multicolumn{3}{c}{ Faixa Etária } & \multirow{2}{*}{ Total } \\
\cline { 2 - 4 } sua saúde & $<40$ & $40-59$ & $60 \geq$ & \\
\hline Sim & 21 & 23 & 9 & 53 \\
& $30,9 \%$ & $27,7 \%$ & $21,4 \%$ & \\
Não & 47 & 60 & 33 & 140 \\
Total & $69,1 \%$ & $72,3 \%$ & $78,6 \%$ & \\
\hline
\end{tabular}


Os resultados apresentados na Tabela 57 mostram indices próximos aos obtidos na questão anterior, tendo-se que $24,9 \%$ da amostra identifica a presença de problemas na saúde da familia, provocados pelo ruido.

Tabela 57 - Distribuição segundo a identificação de danos causados pelo ruido do tráfego à saúde da familia do entrevistado.

\begin{tabular}{ccc}
\hline Barulho prejudica a saúde da familia & Freqüência & Percentual \\
\hline Sim & 48 & $24,9 \%$ \\
Não & 145 & $75,1 \%$ \\
\hline Total & 193 & $100,0 \%$ \\
\hline
\end{tabular}

Observa-se que nesta questão, também, as mulheres acreditam mais do que os homens que o barulho esteja afetando a saúde da familia $\left(\chi^{2}=\right.$ 6,59; $d f=1 ; p=0,010)$, como demonstra a Tabela 58 , sendo esta associação estatisticamente significante.

Tabela 58 - Distribuição segundo a identificação de danos causados pelo ruido do tráfego à saúde da familia do entrevistado por sexo.

\begin{tabular}{cccc}
\hline Barulho prejudica a & \multicolumn{2}{c}{ Sexo } & Total \\
\cline { 2 - 3 } saúde da familia & Masculino & Feminino & \\
\hline Sim & 10 & 38 & 48 \\
& $14,3 \%$ & $30,9 \%$ & $24,9 \%$ \\
Não & 60 & 85 & 145 \\
& $85,7 \%$ & $69,1 \%$ & $75,1 \%$ \\
\hline Total & $70(36,3 \%)$ & $123(63,7 \%)$ & 193 \\
\hline
\end{tabular}

Embora não seja estatisticamente significativo, a Tabela 59 revela que a faixa etária mais jovem também apresenta uma maior tendência em acreditar que o barulho do tráfego afeta a saúde da familia $\left(\chi^{2}=4,88\right.$; $d f=2$; $p=0,087$ ). 
Tabela 59 - Distribuição da identificação de danos causados pelo ruido do tráfego à saúde da familia do entrevistado por faixa etária.

\begin{tabular}{ccccc}
\hline $\begin{array}{c}\text { Barulho prejudica } \\
\text { a saúde da }\end{array}$ familia & $<40$ & $40-59$ & $>=60$ & \multirow{2}{*}{ Total } \\
\cline { 2 - 4 } Sim & 23 & 18 & 7 & 48 \\
& 33,8 & $21,7 \%$ & $16,7 \%$ & \\
Não & 45 & 65 & 35 & 145 \\
& $66,2 \%$ & $78,3 \%$ & $83,3 \%$ & \\
\hline Total & $68(35,2 \%)$ & $83(43,0 \%)$ & $42(21,8 \%)$ & 193 \\
\hline
\end{tabular}

Os resultados até agora apresentados revelam que o ruído do tráfego urbano provoca incômodo na grande maioria da amostra, entretanto através da Tabela 60 , verifica-se que a maioria $(60,6 \%)$ das pessoas entrevistadas acreditam que esta ainda não é a área residencial de Brasilia em que se tem o pior problema de poluição sonora.

Os dados não revelam qualquer diferença de comportamento, quando avaliado conjuntamente com as variáveis sexo e faixa etária.

Tabela 60 - Distribuição da identificação da existência de áreas residenciais piores, quanto à presença do ruido causado pelo tráfego urbano.

\begin{tabular}{ccc}
\hline $\begin{array}{c}\text { Existência de áreas piores quanto à } \\
\text { Poluição sonora na cidade }\end{array}$ & Freqüência & Percentual \\
\hline Sim & 117 & 60,6 \\
Não & 37 & 19,2 \\
Não sei & 39 & 20,2 \\
\hline Total & 193 & $100,0 \%$ \\
\hline
\end{tabular}

Considerando os resultados da Tabela 61, observa-se que cerca da metade da amostra $(48,7 \%)$ é otimista quanto ao problema e acha que há possibilidade de se reduzir o ruido, mas a maioria já não tem a mesma perspectiva, prevendo não haver alternativa no futuro para que isso aconteça. 
Tabela 61 - Distribuição segundo a existência de perspectiva de redução do nivel de ruído de tráfego na área de estudo.

\begin{tabular}{ccc}
\hline $\begin{array}{c}\text { Perspectiva de redução do nivel de } \\
\text { ruido de tráfego na área de estudo }\end{array}$ & Frequência & Percentual \\
\hline Sim & 94 & $48,7 \%$ \\
Não & 99 & $51,3 \%$ \\
\hline Total & 193 & $100,0 \%$ \\
\hline
\end{tabular}

Os homens são bem mais otimistas que as mulheres, pois $66 \%$ deles têm a expectativa de que o problema possa ser reduzido enquanto apenas $39 \%$ das mulheres apresentam a mesma opinião $\left(\chi^{2}=12,72 ; d f=1 ; \quad p=0,00\right)$. Esta associação é estatisticamente significante como mostra a Tabela 62.

Tabela 62 - Distribuição segundo a existência de perspectiva de redução do nivel de ruido de tráfego na área de estudo por sexo.

\begin{tabular}{cccc}
\hline \multirow{2}{*}{$\begin{array}{c}\text { Perspectiva de redução do } \\
\text { nivel de ruido de tráfego na } \\
\text { área de estudo }\end{array}$} & \multicolumn{2}{c}{ Sexo } & \multirow{2}{*}{ Total } \\
\cline { 2 - 4 } Sim & Masculino & Feminino & \\
\hline & 46 & 48 & 94 \\
Não & $65,7 \%$ & $39,0 \%$ & $48,7 \%$ \\
& 24 & 75 & 99 \\
Total & $34,3 \%$ & $61,0 \%$ & $51,3 \%$ \\
\hline & $70(36,3 \%)$ & $123(63,7 \%)$ & 193 \\
\hline
\end{tabular}

Os dados da Tabela 63 mostram que os maiores de 60 anos vêem menos possibilidades para a redução do ruído na área de estudo do que os demais e esta associação é estatisticamente significante $\left(\chi^{2}=12,94 ; d f=2\right.$; $p=0,001)$

Tabela 63 - Distribuição segundo a existência de perspectiva de redução do nivel de ruido de tráfego na área de estudo por faixa etária

\begin{tabular}{ccccc}
\hline $\begin{array}{c}\text { Perspectiva de redução do } \\
\text { nivel de ruido de tráfego na }\end{array}$ & \multicolumn{4}{c}{ Faixa Etária } \\
\cline { 2 - 4 } área de estudo & $<40$ & $40-59$ & $60>=$ & \\
\hline Sim & 33 & 50 & 11 & 94 \\
& $48,5 \%$ & $60,2 \%$ & $26,2 \%$ & $48,7 \%$ \\
Não & 35 & 33 & 31 & 99 \\
& $51,5 \%$ & $39,8 \%$ & $73,8 \%$ & $51,3 \%$ \\
\hline Total & 68 & 83 & 42 & 193 \\
& $35,2 \%$ & $43,0 \%$ & $21,8 \%$ & \\
\hline
\end{tabular}




\subsection{6 - Caracterização do Grupo Mais Atingido pelo Problema}

Os resultados revelam não haver associação estatisticamente significante entre as pessoas que dariam prioridade à ausência de ruido na escolha de uma área para moradia e o nivel de sensibilidade por elas definido.

A relação entre nivel de sensibilidade e o tempo de exposição da amostra ao ruido, durante os dias úteis, também, não revelou qualquer associação estatística.

$\mathrm{Na}$ Tabela 64, verifica-se que as pessoas que se autodefiniram como de alta sensibilidade ao ruido são, na sua maioria, aquelas que identificaram os apartamentos como muito barulhentos e barulhentos $\left(\chi^{2}=36,14 ; \mathrm{df}=4 ; p=\right.$ 0.000 ), sendo esta associação estatisticamente significante.

Tabela 64 - Distribuição da amostra segundo o nivel de sensibilidade ao ruido e a identificação do nivel de barulho do apartamento.

\begin{tabular}{ccccc}
\hline $\begin{array}{c}\text { Nivel de } \\
\text { sensibilidade }\end{array}$ & \multicolumn{3}{c}{ Nivel de barulho do apartamento } & Total \\
\hline & Muito barulho & Barulhento & $\begin{array}{c}\text { Moderado } \\
\text { /silencioso }\end{array}$ \\
\hline Alta & 47 & 20 & 12 & 79 \\
& $68,1 \%$ & $33,8 \%$ & $18,4 \%$ & $41 \%$ \\
Média & 18 & 30 & 40 & 88 \\
& $26 \%$ & $50,8 \%$ & $61,5 \%$ & $46 \%$ \\
Baixa & 4 & 9 & 13 & 26 \\
& $5.9 \%$ & $15,4 \%$ & $19.1 \%$ & $13 \%$ \\
\hline Total & 69 & 59 & 65 & 193 \\
& $35.7 \%$ & $30.5 \%$ & $33.8 \%$ & $100 \%$ \\
\hline
\end{tabular}

Na Tabela 65. observa-se que a maioria das pessoas que se identificam como mais sensiveis ao ruido tendem a ser, tambèm, as que se sentem incomodadas pelo ruido, entretanto não foi possivel a análise estatistica através do $\chi^{2}$ pelo fato de a tabela apresentar resultados com valores $<5$ 
Tabela 65 - Distribuição segundo o nivel de sensibilidade ao ruído e a identificação de incômodo com o ruído de tráfego.

\begin{tabular}{|c|c|c|c|}
\hline \multirow[t]{2}{*}{ Nivel de Sensibilidade } & \multicolumn{2}{|c|}{ Incomoda com o ruido } & \multirow[t]{2}{*}{ Total } \\
\hline & $\operatorname{sim}$ & não & \\
\hline Alta & 76 & 3 & 79 \\
\hline & $44 \%$ & $14 \%$ & $41 \%$ \\
\hline Média & $\begin{array}{c}80 \\
47 \%\end{array}$ & $\begin{array}{c}8 \\
36 \%\end{array}$ & $\begin{array}{c}88 \\
46 \%\end{array}$ \\
\hline Baixa & $\begin{array}{l}15 \\
9 \%\end{array}$ & $\begin{array}{c}11 \\
50 \%\end{array}$ & $\begin{array}{c}26 \\
13 \%\end{array}$ \\
\hline Total & $\begin{array}{c}171 \\
89 \%\end{array}$ & $\begin{array}{c}22 \\
11 \%\end{array}$ & $\begin{array}{c}193 \\
100 \%\end{array}$ \\
\hline
\end{tabular}

Na Tabela 66, observa-se que os dados indicam que a maioria das pessoas que se auto classificaram como mais sensiveis ao ruido do tráfego são aquelas que sentem um alto nivel de incômodo; entretanto também não foi possivel a análise estatistica através do $\chi^{2}$ diante do fato de a tabela apresentar resultados com valores $<5$.

Tabela 66 - Distribuição segundo o nivel de sensibilidade ao ruído e a identificação do incômodo com o ruido de tráfego.

\begin{tabular}{|c|c|c|c|c|c|}
\hline \multirow{2}{*}{$\begin{array}{c}\text { Nivel de } \\
\text { sensibilidade }\end{array}$} & \multicolumn{4}{|c|}{ Nivel de incômodo } & \multirow[t]{2}{*}{ Total } \\
\hline & Pouco & Médio & Muito & Nenhum & \\
\hline Alta & $\begin{array}{c}8 \\
27 \%\end{array}$ & $\begin{array}{c}18 \\
25 \%\end{array}$ & $\begin{array}{c}50 \\
72 \%\end{array}$ & $\begin{array}{c}3 \\
14 \%\end{array}$ & $\begin{array}{c}79 \\
41 \%\end{array}$ \\
\hline Média & 12 & $\begin{array}{c}51 \\
72 \%\end{array}$ & $\begin{array}{c}17 \\
24 \%\end{array}$ & $\begin{array}{c}8 \\
36 \%\end{array}$ & 88 \\
\hline Baixa & $\begin{array}{c}40 \% \\
10 \\
33 \%\end{array}$ & $\begin{array}{c}72 \% \\
2 \\
3 \%\end{array}$ & $\begin{array}{c}24 \% \\
3 \\
4 \%\end{array}$ & $\begin{array}{c}36 \% \\
11 \\
50 \%\end{array}$ & $\begin{array}{c}46 \% \\
26 \\
13 \%\end{array}$ \\
\hline Total & $\begin{array}{c}30 \\
16 \%\end{array}$ & $\begin{array}{c}71 \\
37 \%\end{array}$ & $\begin{array}{c}70 \\
36 \%\end{array}$ & $\begin{array}{c}22 \\
11 \%\end{array}$ & $\begin{array}{c}193 \\
100 \%\end{array}$ \\
\hline
\end{tabular}

Observa-se, através da Tabela 67 , que embora os resultados indiquem que a maioria das pessoas que se revelam incomodadas pelo ruído são aquelas que avaliam seus apartamentos como muito barulhentos $\mathrm{e}$ barulhentos; não foi também possivel a análise estatistica através do $\chi^{2}$ : a tabela apresenta resultados com valores $<5$ 
Tabela 67 - Distribuição segundo o nivel de barulho do apartamento e a identificação do incômodo com o ruido de tráfego.

\begin{tabular}{lccc}
\hline \multirow{2}{*}{$\begin{array}{c}\text { Nivel de barulho do } \\
\text { apartamento }\end{array}$} & \multicolumn{2}{c}{$\begin{array}{c}\text { Incomoda-se com o } \\
\text { ruido }\end{array}$} & \multirow{2}{*}{ Total } \\
\cline { 2 - 3 } & Sim & Não & \\
\hline Muito barulho & 67 & 2 & 69 \\
& $39 \%$ & $9,1 \%$ & $36 \%$ \\
Barulhento & 55 & 4 & 59 \\
& $32 \%$ & $18,2 \%$ & $31 \%$ \\
Moderado/silencioso & 49 & 16 & 63 \\
& $29 \%$ & $72,7 \%$ & 33 \\
\hline Total & 171 & 22 & 193 \\
& $89 \%$ & $11 \%$ & $100 \%$ \\
\hline
\end{tabular}

Foram realizados cruzamentos entre a variável que identifica o incômodo com o ruído, tanto com a variável tempo de permanência diária como com a variável tempo de moradia na residência. Entretanto em nenhum deles houve identificação de associação estatística, revelando não haver, de forma integral na amostra, a associação entre o tempo de exposição e a reação de incômodo.

Os resultados da Tabela 68 mostram que as pessoas mais sensiveis ao ruído do tráfego urbano são aquelas que mais identificam sua interferência em suas atividades, sendo estatisticamente significantes $\left(\chi^{2}=\right.$ 32,$44 ; d f=2 ; p=0.000$ ).

Tabela 68 - Distribuição segundo a interferência em atividades diárias e o nivel de sensibilidade ao ruido.

\begin{tabular}{ccccc}
\hline Interfere nas & \multicolumn{3}{c}{ Nivel de sensibilidade ao ruido } & \multirow{2}{*}{ Total } \\
\cline { 2 - 4 } atividades & Alta & Média & Baixa & \\
\hline \multirow{2}{*}{ Sim } & 73 & 61 & 10 & 144 \\
Não & $92,4 \%$ & 69,3 & $37,5 \%$ & $76,4 \%$ \\
& 6 & 27 & 16 & 49 \\
& $7,6 \%$ & 30,7 & $61.5 \%$ & $23,6 \%$ \\
\hline Total & 79 & 88 & 26 & 193 \\
& 40,9 & 45,5 & 13,6 & $100 \%$ \\
\hline
\end{tabular}


Considerando os resultados apresentados na Tabela 69 verifica-se também que a maioria das pessoas que revelam incômodo com o ruido do tráfego urbano são aquelas que também identificam comprometimento na realização de suas atividades diárias, sendo esta associação estatisticamente significante $\left(\chi^{2}=24,00 ; d f=1 ; p=0,000\right)$.

Tabela 69 - Distribuição segundo a interferência em atividades diárias e a identificação de incômodo.

\begin{tabular}{cccc}
\hline Interfere nas & \multicolumn{2}{c}{ Incomoda } & \multirow{2}{*}{ Total } \\
\cline { 2 - 3 } atividades & Sim & não & \\
\hline Sim & 137 & 7 & 144 \\
& $80,1 \%$ & $31,8 \%$ & $76,4 \%$ \\
Não & 34 & 15 & 49 \\
& $19,2 \%$ & $68,2 \%$ & $23,6 \%$ \\
\hline Total & 171 & 22 & 193 \\
& 88,6 & 21,4 & $100 \%$ \\
\hline
\end{tabular}

A Tabela 70 revela que existe uma associação, estatisticamente significante $\left(\chi^{2}=53,45 ; d f=3 ; p=0,000\right)$, entre o nivel de incômodo sentido pelas pessoas que percebem o ruido do tráfego e a identificação de interferência na realização das atividades. Portanto as pessoas mais incomodadas pelo ruido são aquelas que sofrem interferência em suas atividades.

Tabela 70 - Distribuição segundo a interferência em atividades diárias e o nivel de incômodo provocado pelo ruido do tráfego urbano.

\begin{tabular}{|c|c|c|c|c|c|}
\hline \multirow{2}{*}{$\begin{array}{c}\text { Interfere nas } \\
\text { atividades }\end{array}$} & \multicolumn{4}{|c|}{ Nivel de incômodo } & \multirow{2}{*}{ Total } \\
\hline & Pouco & Médio & Muito & Nenhum & \\
\hline \multirow[t]{2}{*}{ Sim } & 14 & 54 & 69 & 7 & 144 \\
\hline & 46,6 & $76 \%$ & $98,6 \%$ & $31,8 \%$ & $76,4 \%$ \\
\hline \multirow{2}{*}{ Não } & 16 & 17 & 1 & 15 & 49 \\
\hline & $52,4 \%$ & $24 \%$ & $1,4 \%$ & $68,2 \%$ & $23,6 \%$ \\
\hline Total & $\begin{array}{c}30 \\
15,5 \%\end{array}$ & $\begin{array}{c}71 \\
36,7 \%\end{array}$ & $\begin{array}{c}70 \\
36,2 \%\end{array}$ & $\begin{array}{c}22 \\
11.6 \%\end{array}$ & $\begin{array}{c}193 \\
100 \%\end{array}$ \\
\hline
\end{tabular}




\section{2 - Análise Canônica dos dados}

Para verificar uma inter-relação mais abrangente entre as variáveis em estudo, desenvolveu-se ainda a análise estatistica de multivariância, onde foi utilizada a Análise Canônica. Ela foi desenvolvida entre dois grupos de variáveis: o primeiro compreende as variáveis que definem o perfil da amostra, como tempo de residência, idade, sexo, nivel de escolaridade e opiniões, gostar ou não da área onde vive, avaliação da qualidade ambiental da cidade de Brasilia e, especificamente, a avaliação da qualidade ambiental da área onde reside; o segundo grupo constitui-se de variáveis que identificam qualquer relação com o ruido como: condições do ruído na area onde vive; prioridade da ausência de ruido na escolha de uma nova residência; auto-avaliação do grau de sensibilidade ao ruido; nivel de ruido da área de residência; susto com o ruido; manutenção de janelas fechadas; nivel de incômodo; costume com o ruido; interferência do ruido nas atividades diárias; interferência para ouvir rádio; interferência na leitura; interferência em conversas; interferência no sono; existência de doença no entrevistado decorrente do ruido; existência de doença em membro da familia decorrente do ruido.

Na Tabela 71 são apresentados os dados referentes aos dois pares das variáveis canônicas: correlação entre as variáveis padrōes dos coeficientes, percentual de variância responsável pela variação canônica, redundância e as correlações canônicas (rc).

Adotou-se, de acordo com as recomendaçōes da própria análise, uma correlação com o valor minimo $r c=0,30$ como indicação da existência de uma correlação canônica estatisticamente significante para fins de interpretação.

Embora as cinco primeiras correlações canônicas ( $\mathrm{rc}$ ) tenham atingido indices superiores a 0,30 , apenas a primeira, que foi $r c=0,63$, e a segunda com o valor de $\mathrm{rc}=0,46$ mostraram-se significativas. Considerando a inclusão de todas as sete correlações canônicas, $\chi^{2}(112)=205,055 ; p=$ 0,000 , retirando-se a primeira tem-se ainda $\chi^{2}(90)=121,024 ; p=0,016$ 
sendo, portanto, ambas significativas. As demais não se mostraram estatisticamente significantes. Consequentemente apenas a primeira correlação canônica e a segunda demonstram relações significativas entre os dois grupos de variáveis.

Tabela 71 - Correlações, Coeficientes Canônicos Padrões, Correlaçōes Canônicas, Percentuais de Variância e Redundância entre as variáveis do perfil da amostra e os efeitos do ruido urbano na qualidade de vida.

\begin{tabular}{|c|c|c|c|c|c|}
\hline \multirow{2}{*}{ Grupos } & \multicolumn{2}{|c|}{$1^{\text {a }}$ Variante Canônica } & \multicolumn{2}{|c|}{$2^{\mathrm{a}}$ Variante Canônica } & \\
\hline & Correlação & Coeficiente & Correlação & Coeficiente & \\
\hline \multicolumn{6}{|l|}{ Grupo 1} \\
\hline $\begin{array}{l}\text { Gostar da área } \\
\text { Qual. amb. cidade } \\
\text { Qual. amb. resid. } \\
\text { Tempo residència } \\
\text { Sexo } \\
\text { Idade } \\
\text { Escolaridade }\end{array}$ & $\begin{array}{r}-0,782 \\
-0,249 \\
-0,695 \\
-0,152 \\
0,271 \\
-0,141 \\
0,061 \\
\end{array}$ & $\begin{array}{r}-0,673 \\
0,321 \\
-0,714 \\
-0,007 \\
0.208 \\
0,032 \\
0.078 \\
\end{array}$ & $\begin{array}{r}-0,048 \\
-0,179 \\
0,044 \\
-0,051 \\
\mathbf{0 , 3 6 9} \\
-\mathbf{0 , 8 5 4} \\
0,089 \\
\end{array}$ & $\begin{array}{r}0,137 \\
-0,125 \\
0,195 \\
0,269 \\
0,403 \\
-0,975 \\
0.091 \\
\end{array}$ & \\
\hline$\%$ variància & 0.18 & & 0.13 & & Total $=0.31$ \\
\hline Redundância & 0.07 & & 0.03 & & Total $=0.10$ \\
\hline \multicolumn{6}{|l|}{ Grupo 2} \\
\hline $\begin{array}{l}\text { Ruido } \\
\text { Ausência de ruido } \\
\text { Sensibilidade } \\
\text { Nivel de ruido } \\
\text { Susto } \\
\text { Janelas } \\
\text { Incômodo } \\
\text { Nivel de incômodo } \\
\text { Costume } \\
\text { Interferência } \\
\text { Ouvir som } \\
\text { Ler } \\
\text { Falar } \\
\text { Dormir } \\
\text { Doença própria } \\
\text { Doença na } \\
\text { Familia }\end{array}$ & $\begin{array}{c}-0,719 \\
0,568 \\
0,473 \\
0,801 \\
0,429 \\
0,500 \\
0,260 \\
0,683 \\
-0,540 \\
0,465 \\
0,503 \\
0,543 \\
0,394 \\
0,591 \\
0,627 \\
0,590\end{array}$ & $\begin{array}{r}-0,253 \\
0,280 \\
0,019 \\
0,375 \\
0,010 \\
0,028 \\
0,264 \\
0,412 \\
-0,098 \\
-0,041 \\
-0,193 \\
0,104 \\
-0,106 \\
0,111 \\
-0,152 \\
0,334\end{array}$ & $\begin{array}{r}-0,080 \\
-0,534 \\
0,015 \\
0,032 \\
0,249 \\
-0056 \\
\mathbf{0 , 4 1 1} \\
\mathbf{0 , 3 1 3} \\
0,012 \\
0,083 \\
-0,201 \\
0,055 \\
-0,077 \\
-0,197 \\
0,155 \\
0,278\end{array}$ & $\begin{array}{r}-0,239 \\
-0,506 \\
-0,077 \\
0,007 \\
0,229 \\
-0,100 \\
0,177 \\
0,471 \\
0,033 \\
0,595 \\
-0,668 \\
0,058 \\
-0,036 \\
-0,738 \\
0.092 \\
0,285\end{array}$ & \\
\hline $\begin{array}{l}\text { \% Variância } \\
\text { Redundância }\end{array}$ & $\begin{array}{l}0,31 \\
0,12\end{array}$ & & $\begin{array}{l}0.05 \\
0.01 \\
\end{array}$ & & $\begin{array}{l}\text { Total }=0,31 \\
\text { Total }=0,13 \\
\end{array}$ \\
\hline Correlação & 0,625 & & 0,463 & & \\
\hline
\end{tabular}


As variáveis do grupo 1 que abordam o perfil da amostra e revelam-se correlacionadas com a primeira variante são: atitude de gostar ou não do local de residência $(-0,782)$ e avaliação da qualidade ambiental da área onde vive $(-\mathbf{0 , 6 9 5})$. Já as variáveis do grupo 2 , que identificam os efeitos do ruido, considerados na pesquisa, a maioria delas se mostra correlacionada de forma significativa com a primeira variante canônica como: avaliação das condições de ruído da àrea de residência (- 0,719); prioridade da ausência do ruido na escolha da residência $(0,568)$; auto-avaliação do grau de sensibilidade ao ruido $(0,473)$; nivel de ruido da área de residência $(0,801)$; susto com o ruído $(0,429)$; manutenção de janelas fechadas $(0,500)$; nivel de incômodo $(\mathbf{0 , 6 8 3})$, costume com o ruído $(-\mathbf{0 , 5 4 0})$; ocorrência de interferência do ruido em atividades diárias $(0,465)$; interferência para ouvir som $(0,503)$; interferência na leitura $(\mathbf{0 , 5 4 3 )}$; interferência em conversas $(0,394)$; interferência no sono $(\mathbf{0 , 5 9 1 )}$; existência de doença no entrevistado decorrente do ruido $(\mathbf{0 , 6 2 7})$; existência de doença em membro da familia decorrente do ruido $(\mathbf{0 , 5 9 0})$. Esses resultados revelam que as variáveis significativas de ambos os grupos estão altamente relacionadas entre si Entre outras palavras, a primeira variante canônica sugere que as pessoas que menos gostam da área onde residem e avaliam como baixa sua qualidade ambiental seriam aqueles que pior avaliam as condições de ruido, priorizam a ausência do ruído em sua área residencial, avaliam com niveis altos sua própria sensibilidade ao ruido e o nivel de ruido do local onde moram. São ainda essas pessoas que mantêm as janelas fechadas, demonstram niveis mais altos de incômodo, não se acostumam com o problema, sofrem interferência negativa do ruido em suas atividades diárias - conversar, ler, dormir e ouvir sons provenientes de televisão, radio ou aparelhos de som - e revelam a existência de doenças em si próprio e na familia como resultado da exposição ao ruído.

A segunda variante canônica ( $r c=0,463$ ) revela que as variáveis sexo e idade do Grupo 1 estão correlacionadas com as variáveis pertencentes ao Grupo 2 tais como: comportamento de se sentir incomodado; nivel do incômodo; prioridade dada à ausência do ruido em 
uma futura residência. Os resultados mostram que as pessoas do sexo feminino $(0,37)$ e as mais jovens $(-0,854)$ sejam aquelas, que embora menos priorizem o fator ausência de ruído na escolha da área de uma futura residência $(-0,534)$ são as que mais sofrem incômodos $(0,411)$, e em niveis mais altos $(0,313)$ pelo ruido existente nas proximidades de sua residência.

Foram realizadas, posterior a esta análise, outras tentativas de análise canônica utilizando-se diferentes composições de variáveis nos respectivos grupos mas não foram identificadas alterações significativas nos resultados. As mesmas variáveis identificadas como relevantes e importantes nesta análise se destacaram nas demais tentativas.

\section{3 - Medições do Ruído de Tráfego na Área de Estudo}

As medições foram feitas ao longo do Eixo $R \mathrm{~W}$, onde estão dispostos os blocos residenciais, que apresenta duas pistas, com sentidos opostos, sendo que cada uma delas possui duas faixas de rolamento com $3,5 \mathrm{~m}$ de largura. Essa via compõe, juntamente com o eixo central e o Eixo $\mathrm{RL}$, as vias principais de ligação da Asa Norte à Asa Sul, da cidade de Brasilia, e apresentam um tráfego variado de veículos de passeio e carga e são, também, os principais corredores do Transporte Coletivo.

Foram definidos quatro pontos de medição. Considerando que a pesquisa tem como área de abrangência tanto a Asa sul como a Asa Norte, trabalhou-se com dois pontos em cada uma delas. Na localização dos pontos de medição foram considerados o comportamento diário e semanal do tráfego da via. As medições foram feitas nas quadras 104 e 107, da Asa Sul, e nas quadras de mesmo número da Asa Norte; foram feitas ao longo da pista, nos niveis térreos dos blocos e nos apartamentos com janelas fechadas e em alguns com janelas abertas.

As Tabelas 72 e 73 mostram que a média dos niveis de ruido obtida próxima à pista varia de $76,1 \mathrm{~dB}(\mathrm{~A})$ e $77,7 \mathrm{~dB}(\mathrm{~A})$ e que a obtida no nivel térreo dos blocos já é inferior, estando a variação da média entre $66 \mathrm{~dB}(\mathrm{~A})$ e $69 \mathrm{~dB}(\mathrm{~A})$. Quanto aos niveis de ruido obtidos nos apartamentos observa-se 
que eles variam entre $53 \mathrm{~dB}(\mathrm{~A})$ e $62 \mathrm{~dB}(\mathrm{~A})$ com janelas fechadas e com janelas abertas já se apresentam bem superiores estando entre $67,8 \mathrm{~dB}(\mathrm{~A})$ e $71 \mathrm{~dB}(\mathrm{~A})$

Tabela 72 - Niveis de ruido (leq) medidos na área de estudo - periodo da manhã - $d B(A)$

\begin{tabular}{|c|c|c|c|c|}
\hline \multirow[t]{2}{*}{ 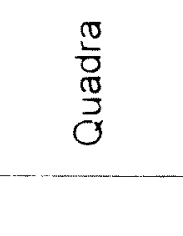 } & \multirow[t]{2}{*}{ Blocos } & \multirow[t]{2}{*}{ Dia } & \multicolumn{2}{|c|}{$\begin{array}{c}\text { Manhã } \\
\text { (7h30min-7h55min) }\end{array}$} \\
\hline & & & Pista & Térreo \\
\hline 104 Norte & $\mathrm{J} / \mathrm{K}$ & $\begin{array}{l}2 a \\
5 a\end{array}$ & $\begin{array}{l}76,6 \\
76,4\end{array}$ & $\begin{array}{l}66,0 \\
68,0\end{array}$ \\
\hline 107 Nonto & $H$ & $4 a$ & 77,2 & 69,1 \\
\hline 1ut None & $\pi$ & $6 a$ & 77.9 & 66,5 \\
\hline 104 Sul & $\mathrm{J} / \mathrm{K}$ & $\begin{array}{l}4 a \\
6 a\end{array}$ & $\begin{array}{l}76,1 \\
77,0 \\
\end{array}$ & $\begin{array}{l}68,9 \\
69,0 \\
\end{array}$ \\
\hline $107 \mathrm{Sul}$ & $J / K$ & $\begin{array}{l}3 a \\
6 a\end{array}$ & $\begin{array}{l}75.5 \\
76.1\end{array}$ & $\begin{array}{l}66.9 \\
68.5\end{array}$ \\
\hline
\end{tabular}

OBS. JA- Janelas abertas JF- Janelas fechadas

Tabela 73 - Niveis de ruido (leq) medidos na área de estudo - período da tarde - $d B(A)$

\begin{tabular}{|c|c|c|c|c|c|c|c|}
\hline \multirow{2}{*}{$\begin{array}{l}\frac{\pi}{0} \\
\stackrel{0}{0} \\
\stackrel{0}{O}\end{array}$} & \multirow[t]{2}{*}{ Blocos } & \multirow[t]{2}{*}{ Dia } & \multicolumn{5}{|c|}{$\begin{array}{c}\text { Periodo - Tarde (unidade - dB(A)) } \\
\qquad(17 \mathrm{~h} 45 \mathrm{~min}-19 \mathrm{~h} 30 \mathrm{~min})\end{array}$} \\
\hline & & & Pista & Térreo & Apt 100 & Apt 300 & Apt 600 \\
\hline & & $2 a$ & 76.5 & 69,0 & $61,9(\mathrm{JF})$ & $55,3(\mathrm{JF})$ & 61,0 (JF) \\
\hline 104 Norte & $J / K$ & $5 a$ & 76.5 & 65,1 & $56,6(\mathrm{JF})$ & $54,2(\mathrm{JF})$ & $\begin{array}{l}61,0(\mathrm{JF}) \\
71.0 \text { (JA) }\end{array}$ \\
\hline & & $4 a$ & 74,6 & 66.9 & & & \\
\hline 107 Norte & $\mathrm{H}$ & $6 a$ & 77.9 & 68,3 & $\begin{array}{l}56.6(\mathrm{JF}) \\
69.8(\mathrm{JA})\end{array}$ & $\begin{array}{l}55,0(\mathrm{JF}) \\
71,0 \text { (JA) }\end{array}$ & $\begin{array}{l}59,8(\mathrm{JF}) \\
70.5(\mathrm{JA})\end{array}$ \\
\hline 104 Sul & $\mathrm{J} / \mathrm{K}$ & $\begin{array}{l}4 a \\
6 a\end{array}$ & 76,1 & 68,0 & $\begin{array}{l}55,0 \text { (JF) } \\
71,0 \text { (JA) }\end{array}$ & $\begin{array}{l}53,0(\mathrm{JF}) \\
70,0(\mathrm{JA})\end{array}$ & $\begin{array}{l}55,7 \text { (JF) } \\
68,8 \text { (JA) }\end{array}$ \\
\hline $107 \mathrm{Sul}$ & $\mathrm{J} / \mathrm{K}$ & $\begin{array}{l}3 a \\
6 a\end{array}$ & 77,1 & 68,2 & $\begin{array}{l}52,0(\mathrm{JF}) \\
67,8(\mathrm{JA}) \\
\end{array}$ & $\begin{array}{l}62,0(\mathrm{JF}) \\
70,0(\mathrm{JA}) \\
\end{array}$ & $\begin{array}{l}52,0(\mathrm{JF}) \\
68,0(\mathrm{JA}) \\
\end{array}$ \\
\hline
\end{tabular}

OBS: JA - Janelas abertas JF- Janelas fechadas 
Considerando que o acréscimo de $3 \mathrm{~dB}(\mathrm{~A})$ a um determinado nivel de ruido compreende a duplicação de sua intensidade, verifica-se que para que para que os apartamentos mantenham-se próximos ao nivel de ruido recomendável é necessário que as janelas sejam conservadas sempre fechadas. A abertura das janelas gera um acréscimo. no nivel de ruído, de 13 a $20 \mathrm{~dB}(\mathrm{~A})$ o que implica em um aumento de sua intensidade em mais de dez vezes justificando, assim, o comportamento dos moradores de manterem suas janelas fechadas permanentemente. 


\section{8 - DISCUSSÃO}

\section{1 - Niveis de Ruído Encontrados na Área de Estudo}

Os resultados das medições dos indices de ruido. realizadas na área de estudo. mostraram valores dos niveis de ruido, com as janelas abertas. superiores em até $15 \mathrm{~dB}(\mathrm{~A})$, aos limites recomendados para os periodos diurno $(55 \mathrm{~dB}(\mathrm{~A}))$ e noturno $(50 \mathrm{~dB}(\mathrm{~A}))$. Os niveis de ruido obtidos com as janelas dos ambientes fechadas mostraram-se também superiores aos recomendados para ambos os periodos, ultrapassando-os em até $7 \mathrm{~dB}(\mathrm{~A})$.

Considerando que o ruido se comporta em uma escala logaritmica, os niveis de ruido detectados significam a ocorrência de uma intensidade muito grande e bem acima dos niveis recomendados nas residências. Esses niveis comprometem as condições de qualidade ambiental e. portanto, verifica-se que o problema de poluição sonora existe na zona residencial lindeira ao eixo RW.

Assim, os resultados comprovam a existência real do problema de poluição sonora na zona residencial lindeira ao Eixo RW. na cidade de Brasilia. Observa-se que a legislação hoje vigente no Distrito Federal recomenda indices de $55 \mathrm{~dB}(\mathrm{~A})$ para os periodos diurnos e $50 \mathrm{~dB}(\mathrm{~A})$ para os periodos noturnos, nas zonas residenciais, sendo que esses indices devem ser alcançados com as janelas abertas.

Conclui-se, então, que os indices de ruido detectados tanto na área externa como nas residências caracterizam uma situação problemática de poluição sonora na área de estudo. Considerando as caracteristicas do plano urbanístico da cidade de Brasilia pode-se prever que este problema atinja a cidade em maior escala. pois há uma grande oferta residencial multifamiliar ao longo de todo o eixo rodoviário $W($ oeste) e, também, ao longo do eixo rodoviário $L$ (leste). 


\section{2 - Qualidade Ambiental da Área de Estudo.}

A amostra revelou gostar da área onde reside e a localização da residência foi considerada como um fator de maior valor dentre as caracteristicas da área. Essa atitude de gostar da àrea è bem mais comum entre as pessoas mais idosas e naquelas que estão residindo na área há mais tempo.

A poluiçäo sonora nas proximidades da residência foi considerada, peia amostra, como a segunda caracteristica negativa da cidade. sendo precedida apenas pelo clima que foi citado por alguns como o elemento mais desagradável.

A qualidade ambiental, tanto da cidade quanto das quadras residenciais em estudo. foi avaliada como boa ou ótima pela maioria. Os homens avaliam a cidade de forma mais favoràel do que as mulheres. As pessoas que residem na àrea há mais tempo avaliam-na, também, de forma mais positiva. Existe ainda uma tendència de as pessoas mais idosas avaliarem a àrea onde moram de uma forma mais positiva e mais benevolente do que as mais jovens.

Das caracteristicas que foram colocadas para análise, foi considerado como pior o ruido do tráfego urbano, sendo péssima a situação da área quanto a este aspecto. A qualidade do tráfego e a segurança não são apresentadas como boas para os residentes da área. Os aspectos, tais como: segurança, nivel de poluição do ar. oferta de espaços de lazer, limpeza urbana e transporte coletivo foram avaliados como razoáveis e bons. caracterizando um atendimento regular aos entrevistados. A oferta de área verde, nos espaços públicos. atende com qualidade as necessidades dos moradores..

$\mathrm{Na}$ escolha de uma nova residência. a garantia de segurança é a primeira prioridade a ser atendida e a ausência de ruído está em segundo lugar sendo seguidas pelas garantias de uma boa qualidade do ar e a assistência dos serviços de limpeza urbana. 
Embora a amostra tenha identificado outros problemas. tanto em sua área residencial como na cidade de Brasilia, os dados revelam que esses não säo ainda relevantes, pois a maioria gosta de onde mora e avalia a qualidade do ambiente como boa e até ótima para se viver. Esse aspecto é comprovado quando se constata que a maioria reside na area há mais de quatro anos e que grande parte das pessoas idosas reside em seus apartamentos há mais de quinze anos.

Portanto os problemas identificados na área não justificam a necessidade de mudança de residência, sendo possivel a convivência com a situaçăo.

O problema do ruido urbano existe. é percebido pelas pessoas que residem na área de estudo e foi avaliado negativamente por todos. Sua presença, na área, é um fator de depreciação dos imóveis de uso residencial, de até $10 \%$ de seu valor, segundo informações obtidas no mercado imobiliário.

\section{3 - Sensibilidade e Percepção do Ruído do Tráfego Urbano}

A maioria da amostra fica pouco tempo em casa no horário útil do dia e o estudo revela que as pessoas que mais ficam em casa neste periodo são as do sexo feminino e as de maior idade.

As pessoas que compōem a amostra mostram-se sensiveis ao ruido e a grande maioria revelou ter uma sensibilidade de média a alta quanto a este aspecto. É revelada uma tendência de que as mulheres e os mais jovens sejam mais sensiveis do que os demais.

O ambiente interno das residências foi considerado, de um modo geral, barulhento. As mulheres são mais severas quanto à avaliação negativa desse aspecto. As pessoas mais idosas apresentam comportamento diverso, pois poucas caracterizam seus apartamentos como barulhentos.

Embora não tenham sido constatadas, nas medições de ruído, grandes diferenças entre as bairros. as pessoas que residem na Asa Sul se 
sentem expostas a uma intensidade de ruido mais alta do que aquelas que residem na Asa Norte.

Grande parte da amostra reside há um tempo razoável na área e já se diz acostumada com o ruido do tráfego urbano nas proximidades de sua residência, não demonstrando ser afetada quando ocorrem variações bruscas do nivel de ruido proveniente do tráfego local. Entretanto este comportamento revela-se mais evidente nos homens, pois as mulheres se mostram menos acostumadas com o problema e ainda se assustam bastante, bem mais do que eles, quando acontecem niveis pontuais intensos de ruido no tráfego.

A maioria da amostra revela ser realmente incomodada em niveis razoaveis, caracterizando o convívio diário como uma situação desagradável quanto ao problema de poluição sonora. Esse comportamento é comprovado pelo fato de a maioria da população manter suas janelas sempre fechadas ao longo de todo o dia, para atenuar o problema, havendo uma tendência de que as pessoas mais jovens adotem mais este comportamento do que as demais.

A grande maioria se mostra incomodada com niveis de médio a alto, sendo que mais de um terço encontra-se altamente incomodada com o problema. As pessoas do sexo feminino e os mais jovens revelam-se mais incomodados que os demais.

Mais uma vez tem-se a comprovação de que as mulheres tem menor tolerância ao ruido pois são incomodadas de forma mais intensa. Já as pessoas idosas mostram um comportamento diferenciado sendo este o grupo que se mostra menos afetado pelo problema.

O ruido do tráfego nesta área não é um problema pontual que acontece em determinados dias ou periodos do dia mas, sim, constante e permanente para essa população. As pessoas sofrem esse incômodo ao longo de todos os dias, principalmente nos dias úteis, sendo mais intenso nos periodos do início da manhã e à noite, que se caracterizam como periodos de pico do tráfego da cidade e também como os periodos em que as pessoas que trabalham fora encontram-se em casa. 
Considerando o aspecto climático da cidade de Brasilia, o problema do ruido nessas áreas gera outro problema ambiental às pessoas nela residentes. As janelas fechadas comprometem a necessidade básica de ventilação direta e permanente nas residências, deixando como opção a utilização de equipamentos para supri-la.

\section{4 - Efeitos do Ruído do Tráfego Urbano}

O ruido do tráfego compromete a qualidade de vida e o bem-estar da população, pois além de gerar incômodos interfere na realização de atividades básicas e rotineiras, tais como: dormir, estudar, assistir televisão. trabalhar e até conversar. As mulheres, mais uma vez, demonstram ser mais sensiveis, reclamando que o barulho interfere mais frequentemente em suas atividades.

Apenas uma minoria. na amostra, não se mostrou incomodada em suas atividades. A maioria. entretanto sente-se prejudicada de alguma forma na realização de suas atividades, identificando, pelo menos uma interferência: o sono foi a atividade considerada como a mais afetada pelo ruido. Levando em conta que uma boa qualidade de sono é primordial para a garantia de uma boa saúde, observa-se ai a ocorrencia de mais um fator de seu comprometimento.

As mulheres se sentem mais incomodadas quando estão ouvindo som, rádio ou TV do que os homens, enquanto os mais jovens são mais afetados na atividade de leitura.

Considerando a discussão teórica (capitulo 6) no que se refere às dificuldades na identificação e na percepção de doenças que podem ser causadas pela exposição ao ruido urbano, ainda assim, foram identificados por uma minoria, ou melhor, por um quarto da amostra, casos de problemas de saúde em membros de uma mesma familia. Esse fato revela que a dimensão dos impactos negativos do ruído urbano, na área de estudo, não é irrelevante e aponta para a necessidade de atenção ao problema. 
A maioria da amostra é de opinião que, na cidade de Brasilia, há áreas residenciais que apresentam uma poluição sonora mais comprometedora para o convivio do que as descritas para a área em que residem. Em sua maioria. è pessimista quanto à possibilidade de melhoria ou solução do problema do ruído do tráfego urbano na área em que vivem há tanto tempo. Entretanto bem mais de um terço da população da amostra revela uma perspectiva otimista, prevendo a possibilidade de que a situação seja contornada. Os homens, em geral, comportam-se de forma mais positiva do que as mulheres quanto a essa questão. Já os mais idosos acham mais difícil a solução do problema .

\section{5 - Caracterização do Grupo que Sofre Maiores Impactos}

Posterior à análise dos resultados especificos das questōes, foi ainda desenvolvido um estudo dos comportamentos apresentados frente ao ruido do tráfego buscando-se identificar a relação entre perfil e comportamento do grupo da amostra mais sensivel ao problema.

As pessoas mais sensiveis ao ruido são aquelas que qualificam seus apartamentos como barulhentos e, também, aquelas que se sentem mais incomodadas por sua interferência no desenvolvimento de suas atividades diárias. Todas essas relações se mostram-se estatisticamente significantes. Considerando que as pessoas do sexo feminino são aquelas que sentem com maior intensidade o barulho em suas residências e são também as mais prejudicadas na realização de suas atividades, elas devem compor este

grupo de forma majoritária. Pode-se também verificar que neste mesmo grupo encontram-se as pessoas mais jovens, considerando os resultados anteriormente apresentados.

Tanto a sensação de incômodo como o nivel de sensibilidade ao ruido, revelados pela amostra, não se mostram relacionados com o tempo de exposição. Analisando o comportamento feminino da amostra que se carateriza como um dos grupos que apresenta uma maior reação negativa ao problema e que, ao mesmo tempo, permanece mais tempo em casa, 
pode-se ter uma associação de tempo de exposição e reações negativas ao ruido. Entretanto o grupo de pessoas mais velhas que permanece mais tempo em casa não revela a mesma associação pois sua reação ao ruído é diversa, isto é, a situação não o incomoda. Portanto, neste estudo, a presença do incômodo ao ruido de tráfego não apresenta relação clara e direta com o tempo de exposição . O tempo de exposição ao ruído do tráfego não se mostra um fator indutor na predisposição de causa de incômodo analisando-se a amostra de forma integral.

Não se obteve, também, qualquer relação entre o tempo de exposição ao ruido e o nivel de sensibilidade a ele, sendo, portanto, estas variáveis independentes entre si.

Aqui cabe uma análise mais precisa quanto à relação do tempo de exposição, reação da amostra ao ruído e faixa etária. De acordo com os resultados, as pessoas que mais ficam em casa são as mais idosas e, considerando a literatura sobre o assunto, é relatada uma redução no nível de audiçăo nessas pessoas. Portanto, se este for um comportamento uniforme, pode-se questionar os efeitos do ruido neste grupo; talvez não seja o menos afetado mas sim o que recebe uma intensidade de ruído inferior aos demais, justificando assim um comportamento mais positivo frente ao problema. Observa-se a necessidade de estudos em que a amostra seja composta de um grupo pessoas que não estejam ainda em idade de sofrerem um processo de redução auditiva.

Outro aspecto a ser discutido, aparentemente paradoxal, é o de ser o grupo de pessoas que se sente incomodado aquele que fica menos tempo exposto ao ruido em sua residência; isso se explica pelo fato de que, embora o tempo de exposição seja menor, estes períodos - inicio da manhã e noite - são, ao mesmo tempo, aqueles em que o nível de ruído é mais intenso e, portanto, menos tolerável. Esses periodos são sua referência do incômodo causado pelo ruido em sua área residencial.

Os resultados da análise canônica possibilitam constatar as associações identificadas na análise estatística anterior e também apresentam resultados que demonstram, de uma forma múltipla, as 
correlações existentes entre determinados grupos de variáveis e entre elas próprias, identificando paralelamente a intensidade em que elas ocorrem . Esta análise possibilitou ainda uma análise da correlação entre os comportamentos revelados pela amostra, permitindo a definição de perfis tanto do grupo que mais identifica e sofre com o problema do ruido como daquele que apresenta o comportamento inverso.

Portanto foi constatado que quanto menos as pessoas gostam da área. pior qualificam a qualidade ambiental do lugar, sendo esperado que essas mesmas pessoas sejam aquelas, em ordem de importância, que identificam maior nivel de ruido, que qualificam mais negativamente a área quanto as condições do ruido, que são mais intensamente incomodadas, mais identificam doenças nelas proprias, que mais sofrem interferência no sono, mais identificam doenças na familia decorrente do problema, mais procuram morar em áreas onde não haja barulho, mais sofrem interferência no ato de leitura, são as que menos se acostumam com o ruido, mais mantém as janelas dos ambientes fechadas, mais sofrem interferências na realizaçăo de suas atividades diárias, ainda se assustam com ruídos pontuais e sentem a interferência até mesmo, embora na menor intensidade, na compreensão de conversas ao telefone.

Esses resultados mostram-se congruentes com outros estudos já realizados por Langdon (1976) e Weinstein (1980) e citados por Staples (1996), onde foi identificada a associação indireta entre o comportamento de satisfaçāo e preferência da área onde reside e a percepção de incômodo ao ruido.

Foi também identificada uma correlação entre sexo e idade e comportamentos tais como: baixa prioridade à ausência de ruido nas proximidades da residência; incômodo proveniente do ruido e o nivel de incômodo. Portanto as pessoas de menor idade e, também, as do sexo feminino, são as que menos priorizam a ausência de ruído nas proximidades de uma futura residência sendo, entretanto, as que mais se sentem incomodadas e em maior intensidade. 
A associação entre pessoas mais jovens e ruido e o fato de sentiremse mais incomodadas com o ruido mostra-se congruente com um dos resultados obtido em estudos realizados por Aguirri et al. (1993), descrito em capitulo anterior.

Portanto ambas as análises apresentaram resultados coerentes, assegurando maior credibilidade às conclusões desta pesquisa. 


\section{9 - CONCLUSÃO}

Diante das discussöes apresentadas conclui-se que a maioria da amostra gosta da área onde reside e a avalia como de boa qualidade ambiental. Entretanto, paraleiamente. essa maioria demonstra ser incomodada, e em niveis relevantes, pela poluição sonora existente nas proximidades de suas residências e sofrem interferências negativas em hábitos diários, comprometendo assim sua qualidade de vida.

Caracteriza-se tambem como os grupos mais afetados pelo problema da poluição sonora, o de pessoas mais jovens e o grupo do sexo feminino.

Considerando a associação constatada neste estudo entre 0 ato de gostar da área e o de ser menos incomodado pelo ruído verifica-se que um determinado grupo da amostra não revela este comportamento. Esta situação pode ser justificada pela boa qualidade e localização dos apartamentos existentes na área $\circ$ que favorece o surgimento de preferências pela localidade onde moram. Este fato, entretanto, mostra-se preocupante pois essas pessoas convivem diariamente com a poluição sonora, como foi comprovado, e já sofrem os efeitos negativos à saúde humana.

Os impactos da presença do ruido nas proximidades de uma zona residencial além de gerar comprometimentos na saúde e na qualidade de vida das pessoas atuam, também, em escala mais abrangente e de modo negativo na qualidade ambiental, reduzindo a preferência de moradia nessas áreas.

Considerando haver sido constatada a presença de poluição sonora como problema na cidade de Brasília. o ruido urbano. com impactos negativos na qualidade de vida e consequentemente na saúde de um determinado grupo da população, deve ser considerado como um dos indicadores de qualidade ambiental.

Constata-se que as reações negativas ao problema do ruido, proveniente do tráfego urbano, estão relacionadas diretamente com a percepção, especialmente com a percepção auditiva individual, e estão, 
tambèm, associadas às especifidades do perfil do indivíduo como sexo, idade e preferéncias do lugar onde moram.

Quanto à cidade de Brasilia, embora possa ser considerada uma cidade nova, inaugurada há apenas quarenta anos, ela já apresenta problemas de caráter ambiental próximos aos das grandes metrópoles brasileiras

O plano de Brasilia. seguindo as vertentes do urbanismo modernista, oferece hoje à população uma boa qualidade de vida. Entretanto identificam-se algumas áreas residenciais urbanas comprometidas, quanto à poluição sonora, em função de a prioridade de fluxos contínuos na circulaçăo de veiculos estar caracterizada na proposta do plano urbanístico da cidade.

Embora a pesquisa tenha se limitado apenas à área de residências das superquadras 102-108, em ambas as Asas, a uniformidade dos projetos das superquadras e a disposição das projeções dos edificios permite prever que o problema seja bem maior considerando-se toda a dimensão espacial da cidade.

Há, ainda, em Brasilia, as quadras de uso residencial 400 e 700 que são dispostas lindeiras à Via L2 e à Via W3 que se caracterizam por apresentarem um fluxo continuo de tráfego razoável e horários de pico definidos. Maiores estudos seriam necessários para caracterizar a real dimensão do problema na cidade.

Considerando ainda que o tráfego urbano é a maior fonte de ruído nas cidades, o planejamento do transporte torna-se um dos instrumentos de maior poder no controle deste problema ambiental. O ruído deve, portanto, ser inserido como uma das variáveis a ser atendida no desenvolvimento do planejamento urbano e do transporte.

\section{1- Análise das Hipóteses.}

As conclusões até aqui apresentadas serão analisadas paralelamente às hipóteses formuladas para o desenvolvimento da pesquisa. 
A primeira hipótese $(\mathrm{H} 1)$ de que "o ruido de tráfego existe como um problema ambiental em áreas residenciais na cidade de Brasilia" é comprovada neste estudo. Os resultados de medições dos niveis de ruído na área de estudo acusam niveis superiores aos recomendados pela legislação local, o que caracteriza a existência do problema no meio urbano.

$\mathrm{Na}$ segunda hipótese $(\mathrm{H} 2)$, em que "o ruído é um problema ambiental nas áreas residenciais da cidade de Brasilia e é percebido pela população que prioriza a sua solução", foi comprovada a veracidade de sua primeira parte no parágrafo anterior.

A segunda parte "a população percebe o problema e prioriza a sua soluçāo" é também verdadeira, pois a grande maioria da amostra revela-se incomodada, em graus de intensidade relevantes, e caracteriza sua residência como desconfortável quanto a esse aspecto. $O$ ruido do tráfego não é ignorado na busca de qualidade em uma zona residencial e é ainda um fator de desvalorização de áreas residenciais que apresentam esse incômodo. Essa atitude reflete a percepção da presença do ruido de tráfego na área como um problema.

Quanto à priorização da identificação da variável presença de ruido como segunda na escala de prioridades, apenas precedida pela variável segurança, para a escolha de uma nova residência, reflete o quanto o ruido urbano afeta as pessoas na escolha de uma área com boa qualidade ambiental.

A terceira hipótese $(\mathrm{H} 3)$ de que "o ruído é um problema ambiental nas áreas residenciais da cidade de Brasilia e gera efeitos negativos na saúde na população", é comprovada, considerando que o conceito de saúde, adotado neste estudo, definido pela Organização Mundial da Saúde. é abrangente e extrapola o conceito de saúde como sendo apenas a inexistência de doenças diagnosticadas; neste conceito está inserida a necessidade de garantia do bem-estar e da qualidade de vida como fatores básicos para assegurar a saúde da população.

Diante dos resultados apresentados, o ruido do tráfego gera a sensação de incômodo à grande maioria e, também. interfere na realização 
de atividades básicas e rotineiras em residências, comprometendo a qualidade de vida das pessoas que residem na área. Analisando as especificidades dos efeitos do ruído urbano, observa-se que há atividades que necessitam de concentração, como no caso de leitura e estudo, e de relaxamento e descanso, como na atividade de dormir. Todos esses efeitos, conforme a discussão apresentada por Burns (1973) e Sutter (1991), fazem parte dos efeitos diretos e indiretos dos ruidos por eles identificados e que, embora năo provoquem doenças especificas, interagem com outros fatores provenientes de outras fontes provocando sérios danos à saúde. Esses efeitos são detectados neste estudo e revelam que contribuem para o comprometimento da saúde humana o que vem acontecendo com pessoas que residem nesta área de estudo.

Considerando as discussões sobre a complexidade do processo da percepção e seu envolvimento com caracteristicas físicas e socioculturais do individuo buscou-se analisar, através da Hipótese $4(\mathrm{H} 4)$, a interferência de variaveis que se referem ao perfil $e$ às preferências individuais no comportamento do grupo frente à exposição ao ruido do tráfego urbano. Através deste estudo comprova-se a veracidade desta hipótese constatando-se que variáveis tais como a preferência pela área onde residem, sexo e faixa etária mostram-se altamente correlacionadas com a atitude de percepção do ruido e com a reação na exposição à poluição sonora.

\section{2 - Recomendações}

Diante da pesquisa apresentada e dos resultados obtidos, observa-se que existe um amplo campo de estudos para a análise de lacunas, ainda inexploradas, quanto aos efeitos do ruido na saúde humana e quanto ao estabelecimento de medidas de controle, ainda inexistentes, que minimizem os efeitos da poluição sonora evitando a existência de áreas de uso urbano incompativeis com o que se considera uma boa qualidade ambiental.

Recomenda-se. diante das conclusões apresentadas neste estudo: 
1 - quanto à saúde:

- sejam desenvolvidas pesquisas, utilizando-se amostras homogêneas quanto à faixa etária. para que sejam obtidos resultados mais precisos quanto a esse aspecto;

- sejam reavaliados os niveis de ruido, atualmente propostos pela legislação, como adequados para as zonas residenciais, considerando os efeitos que possam gerar na saúde humana;

- sejam desenvolvidos estudos que possibilitem a análise da relação entre os niveis de estresse das pessoas e o de tolerância ao ruído.

As recomendações acima propostas são decorrentes de questões e dúvidas que não puderam ser esclarecidas diante das limitações desta pesquisa e. também, da identificaçăo de caracteristicas da poluição sonora urbana que são, ainda hoje, desconsideradas no meio profissional.

2. quanto ao planejamento urbano:

- que o potencial de emissão de ruído seja considerado como referência e adotado como indicador de qualidade ambiental urbano pelos planejadores, na proposição do uso e ocupação do solo em áreas urbanas, inibindo a implantação de edificações para uso inadequado e aquelas que envolvam atividades que possam ser comprometidas pela presença da poluição sonora;

- que sejam realizados estudos que analisem usos e atividades incompativeis com o ruido urbano e favoreçam o desenvolvimento do planejamento com vistas à preservação da qualidade ambiental da cidade;

- que se considere, na elaboração de um projeto de sistema viário, a previsão de fluxo, volume e característica do tráfego nas vias, considerando o seu potencial como emissor da poluiçāo sonora;

- que sejam desenvolvidos e incentivados estudos com propostas alternativas de deslocamento que substituam o veículo particular, tais 
como: bicicletas, transporte coletivo e outros, de modo a reduzir o volume de tráfego hoje presente nas áreas urbanas;

- a adoção de nivel de ruído urbano como um indicador de qualidade ambiental urbana em zonas de uso residencial;

No desenvolvimento desta tese, além do atendimento aos objetivos e estudos das hipóteses, houve o interesse de desenvolver uma metodologia para a intensificação de indicadores de qualidade ambiental próprios e característicos das cidades brasileiras para obter-se referência de qualidade de vida coerente com as necessidades culturais e sociais da realidade brasileira. Espera-se que este estudo tenha contribuido para a elaboração desta metodologia, visando o desenvolvimento de políticas de análise, avaliação e monitoramento da qualidade ambiental em áreas urbanas brasileiras. 


\section{1 - REFERÊNCIAS}

[ABNT] Associação Brasileira de Normas Técnicas. NBR 10151 12/1987a Esta norma fixa condiçōes para avaliaçăo da aceitabilidade do ruido em comunidades. Especifica um método para a medição de ruído e aplicação de correções nos niveis medidos. Atualizada Julho de 2000. [available to http:Iwww. www.abnt.org br/serviços. htm - 08/09/2000]

[ABNT] Associação Brasileira de Normas Técnicas. NBR 10152 12/1987b Esta norma fixa os niveis de ruido compatíveis com o conforto acústico em ambientes diversos. Rio de Janeiro. Dezembro de 1987b.

Aguerri SP, Celma CJ. Effects of noise on the citizen and its repercussions on municipal management In: Sixth International Congress on Noise as a Public Health; 1993 jul 5-9; Nice, France: Editora Michel Vallet: 1993. v 2, p. 323-5.

Albers $\mathrm{P}$, Brandl FK. Vehicle noise reduction strategies. In: $1^{\circ}$ Congresso Brasil/Argentina/15 ${ }^{\circ}$ Encontro do SOBRAC; 1994 abril 11-13; Florianópolis, Brasil: Sociedade Brasileira de Acústica; 1994. p 123-44.

Berglund B. Lindvall T [editors]. Community Noise. Archives of the Center for Sensory Research, 1995: 2(1):1-195.

Beristain S. El ruido es un serio contaminante. In: $1^{\circ}$ Congresso Iberoamericano de Acústica: 1998 abril 4-8; Florianópolis. Brasil: Fabio Francisco Nunes; 1998. p. 135-46.

Bertoni D, Franchini A, Margnoni M, Tartoni P, Vallet M. Reactions of people to urban traffic noise in Modena, Italy. In: 6th International Congress on Noise as a Public Health 1993 Jul 5-9; Nice. France: Michel Vallet; 1993. v 2 p. $503-6$ 
Bonnes M. Secchiaroli G. Environmental Psychology. London: Sage Publications; 1995.

Bonnes $M$, Bonaiuto $M$. Ercolani $P$. Crowding and residential satisfaction in the urban environment. Environ Behav 1991; 23(5): 531-52.

Branco S M. Ecossistêmica. São Paulo: Edgard Blücher; 1989..

Brugmann J. Managing urban ecosystems. The International Agency for Local Governments, jan 1992.p.1-20. [Review Copy]

Burns W. Noise and man. London: J B Lippincott Company;1969

Cohen S. Glass DC. Singer JE. Apartment noise auditory discrimination, and reading ability in children. J Exp Soc Psychol.1973; 9: 407-22.

Cohen S, Krantz DS, Evans GW, Stokos D. Cardiovascular and behavioral effects of community noise. Am Sci. 1981: 69: 528-35.

[CONAMA] Conselho Nacional de Meio Ambiente. Resolução no 001, de 08 de março de 1990. Estabelece critérios e padröes para a emissão de ruidos em decorrência de quaisquer atividades industriais. Diário Oficial da União. Brasilia, 2 abr 1990a. Seção 1, p. 6408.

[CONAMA] Conselho Nacional de Meio Ambiente. Resolução $n^{\circ} 002$, de 08.de março de 1990. Institui o Programa Nacional de Educação e Controle da Poluição Sonora. Diário Oficial da União, Brasilia, 2 abr 1990b. Seção 1, p. 6408 .

[CONAMA] Conselho Nacional de Meio Ambiente. Resolução nº 001, de 11 de fevereiro de 1993. Estabelece para os veículos nacionais e importados, 
exceto motocicletas, motonetas, ciclomotores. bicicletas com motor auxiliar e veículos assemelhados. limites máximos de ruido com veículos em aceleração e na condição parado. Diário Oficial da União. Brasilia, 15 fev 1993a. p. $2037-44$

[CONAMA] Conselho Nacional de Meio Ambiente. Resolução $n^{\circ} 8$, de 31 de agosto de 1993. Atualiza o Programa de Controle da Poluição do Ar por Veículos Automotores - PROCONVE com relação a veículos pesados pesados e dá outras providências. Proconve/Ministério do Meio Ambiente- IBAMA. 2 ed. Brasília:IBAMA, 1998.p88-102. [Coleção Meio Ambiente - Série Diretrizes - Gestão Ambiental, n.2].

Cutter LS. Rating places, a geographer's view on quality of life. Washington: Association of American Geographers; 1985.

Distrito Federal. Decreto lei $n^{\circ} 380$, de 11.12.92. Disciplina o uso de carros de som e dá outras providências. Diário Oficial do Distrito Federal, Brasilia. DF, 14 dez 1992.

Distrito Federal. Decreto lei $n^{\circ} 1065$. de 06 de maio de 1996. Dispõe sobre normas de preservação ambiental quanto à poluição sonora, e dá outras providências. Diário Oficial do Distrito Federal, Brasília, DF,10 abril 1996.

Durand M, Harff Y. La qualité de la vie. Paris: Mouton \& Co; 1977.

[ECC] European Community Commission. Green book about the urban environment. Bruxelas; Julho,1990. (Publicações Oficiais da Comunidade Européia)

Evans GW, Hygge S, Bullinger M. Chronic noise and psychological stress. Am Psychol Sci 1995; 6 : 333-8. 
Exline $\mathrm{CH}$, Peters GL, Larkin RP. The city, patterns and processes in the urban ecosystem. Colorado: Westview Press ; 1982.

Fidell S. Nationwide urban noise survey. J Acoust Soc Am 1978; 64: 198206

Fidell S. Baber DS, Schultz TJ. Updating a dosage-effect relationship for the prevalence of annoyance due to general transportation noise. J Acoust Soc Am 1991; 89: 221-33.

Fisher D. Bell A. Baum A. Environmental Psychology. New York: Holt Rinehart \& Winston. 1984

Forattini OP. Ecologia, epidemiologia e sociedade. São Paulo: EDUSP; 1992.

Frick D. The quality of urban life. New York: Walter de Gruyter; 1986.

Goldstein EB. Sensation and perception. Belmont: Wasworth Publishing Company; 1984.

Golledge R. Environmental congnition. In: Stokols D. Aitman I. Handbook of environmental psychology. New York:: Wiley; 1987. p.131-174

Gouveia W. Survey pelo correio sobre percepção do barulho ambiental: variáveis técnicas e de conteúdo. Brasilia: 1991. [ Dissertação de Mestrado - Faculdade de Psicologia da UnB].

[IBAMA] Instituto Brasileiro do Meio Ambiente e dos Recursos Naturais Renováveis. Programa de controle de poluição do ar por veículos automotores-PROCONVE. Brasilia: IBAMA: 1998 
Ishiyama TA. Social survey of community responses to road traffic noise. In: 6th International Congress - Noise as a Public Health; 1993 Jul 5-9; Nice, France: Michel Vallet; 1993. v 2, p. 375-8.

Job SRF. Psychological factors of community reaction to noise. In: 6th International Congress - Noise as a Public Health; 1993 Jul 5-9; Nice, France. França: Michel Vallet; 1993. v.3. p. 48-59.

Lapoix F. Urbanistes et architectes ont pourtant bien réflechi. In: Sauver la ville-ecologie du milieu urbain. Paris: Sang de la Terre; 1991. p. 60-144.

Lawrence $R$ J. Can human ecology provide an integrative framework? In: Steiner D, Nauser M, editors. Human ecology. London: Routledge; 1993. p. 213-28

Lopez RM. Estudio subjetivo del ambiente acústico en los municipios de la comunidade autonoma de Madrid. In: $1^{\circ}$ Congresso Iberoamericano de Acústica; 1998; abr 4-8: Florianópolis, Brasil: Fabio Francisco Nunes; 1998. p. 60-69.

Murgel E. Medidas de controle de ruido em rodovias. In: $1^{\circ}$ Congresso Iberoamericano de Acústica; 1998 abr 4-8; Florianópolis, Brasil: Fabio Francisco Nunes: 1998. P. 267-278 08-13.

Marans R. Bechtel R, Willian M. Methods in environmental and behavior research. New York: Van Nostrand Reinhold Company; 1987. p.52

Mendez MA, Basso JG, Stornini JA, Velis GA, Beorlegui HD. Investigaciones sobre el ruido del transito en La Plata. In: $1^{\circ}$ Congresso Iberoamericano de Acústica; 1998 abr 4-8; Florianópolis, Brasil: Fabio Francisco Nunes; 1998. p. 208-13. 
Ohrstrom E. Long term effects in terms of psychosocial wellbeing, annoyance and sleep disturbance in areas exposed to high levels of road traffic noise. In: 6th International Congress - Noise as a Public Health; 1993 Jul 5-9; Nice, France: Michel Vallet; 1993. v 2, p. 209-11

[OSHA]- Occupational Safety and Health Administration. Noise Control. Washington; 1980.

Palhares AGD, Pavaneilo GL, Vecci AMM. Ruido em ambiente urbano do tráfego veicular. Resultados iniciais da apiicação de uma metodologia de mapeamento sonoro para áreas urbanas e residenciais. In: $1^{\circ}$ Congresso Iberoamericano de Acústica; 1998 abril 4-8; Florianópolis, Brasil: Fábio Francisco Nunes; 1998. p 459-62.

Perloff SH. La Calidad del medio ambiente urbano. Espanha, OikosTau. In: Simposio sobre Poluição Ambiental; 1973. v. 3

Preston V, Taylor SM, Hodge DC. Adjustment to natural and technological hazards; a study of an urban residential community. Environ Behav 1983; 15: $143-63$.

Proshansky HM, Fabian AK. Psychological aspects of the quality of urban life. In Frick D. The quality of urban life. Berlim: Walter de Gruyter; 1986. p. 19-24.

Rapoport A. Aspectos humanos de la forma urbana. Barcelona: Editorial Gustavo Grill S.A; 1977.

Renew W D. Attitudes to road traffic in Brisbane. In: 6th International Congress - Noise as a Public Health; 1993 Jul 5-9; Nice, France: Michel Vallet; 1993. v 2. p. 213-1. 
Russo I. Behlau M. Percepção da fala: análise acústica do português brasileiro. São Paulo: Lovise; 1993.

Serva M. Gestão urbana e qualidade de Vida. Rev Adm Pública 1991; 25 : 219-23

Sobral H R. O meio ambiente e a cidade de São Paulo. São Paulo: McGraw-Hill; 1996.

Solórzano MI. Padrões de resposta e taxa de participação em levantamento de campo: aplicação ao problema do ruido urbano. Brasilia: 1991. Dissertaçăo de Mestrado - Facuidade de Psicologia da UnB].

Stanfeid SA, Sharp D. Gallacher J, Babish W. Road traffic noise, noise sensitivity and psychological disorder. Psychol Med 1993a; 23: 977-85.

Stansfeld S, Gallacher, J, Babisch W, Elwood P. Road traffic noise, noise sensitive and psychiatric disorder preliminary prospective finding from the Caerphilly. In: 6th International Congress - Noise as a Public Health; 1993 Jul 5-9; Nice, France: Michel Vallet; 1993b. v 3. p. 268-71.

Staples SL. Human response to environmental noise. Am Psychol 1996: 2: 143-50.

Stephens $C$. The urban environment. poverty and health in developing countries. Health Policy Plan 1995; 10: 109-21.

Sugden FG. Health protection in the urban Environment. London: Press Redwood Burn; 1980.

Sutter HA. Noise and its effects: [on line] 1991. [available to http:Iwww. nonoise.org/library/suter/suter.htm\#road - 14/12/1999] 
Szwarc A. Shimidt DE. Melo O. Impacto do programa de controle do ruido veicular. São Paulo: CETESB;1992.

Tabachnick BG. Fidell LS. Using muitivariate statistics. New York: Harper Collins Publisher: 1989.

Valadares VM, Nunes NTR. Correlaçōes entre a resposta estimada na comunidade devido ao ruido de tráfego veicular em vias arteriais em Belo Horizonte - MG e seus respectivos niveis de serviço. In: $1^{\circ}$ Congresso Iberoamericano de Acústica; 1998 abr 4-8; Florianópolis, Brasil: Fábio Francisco Nunes; 1998. p. 587-598.

Vera MN, Vila J, Godoy JF. Cardiovascular effects of traffic noise: the role of negative self-statements. Psychol Med. 1994; $24:$ p. 817-27.

Vernier J. O Meio Ambiente. Campinas: Papirus;1992.

Villaschi A. Medeiros AC. O Brasil urbano. perspectiva politico institucional da urbanizaçāo brasileira. Rev Adm Pública 1990; 24: p. 88-121.

Weinstein ND. Community noise problems: evidence against adaptation. $\mathbf{J}$ Environ Psychol 1982; 2: p. 87-97.

[WHO] World Health Organization. Development of environmental health criteria for urban planning. Geneva: 1972. (WHO - Technical Report Series, 511) 
[WHO] World Health Organization. Indoor environment: health aspects of air quality, thermal environment, light and noise. Geneva; 1990. (WHO/EHE/RUD/90.2).

[WHO] Word Health Organization. Epi Info. Epidemiologia em microcomputadores: um sistema de processamento de texto, banco de dados e estatistica [programa de computador]. Atlanta: OPASMHO; $1994 a$

[WHO] World Health Organization. Quality of life assessment. Geneva; 1994b. (WHO/MNH/PSF/9).

[WHO] World Health Organization. Environmental health in urban development; Geneva; 1991. (WHO Environmental Health Newsletter). 
Anexo 1 - Brasília, Setorização 


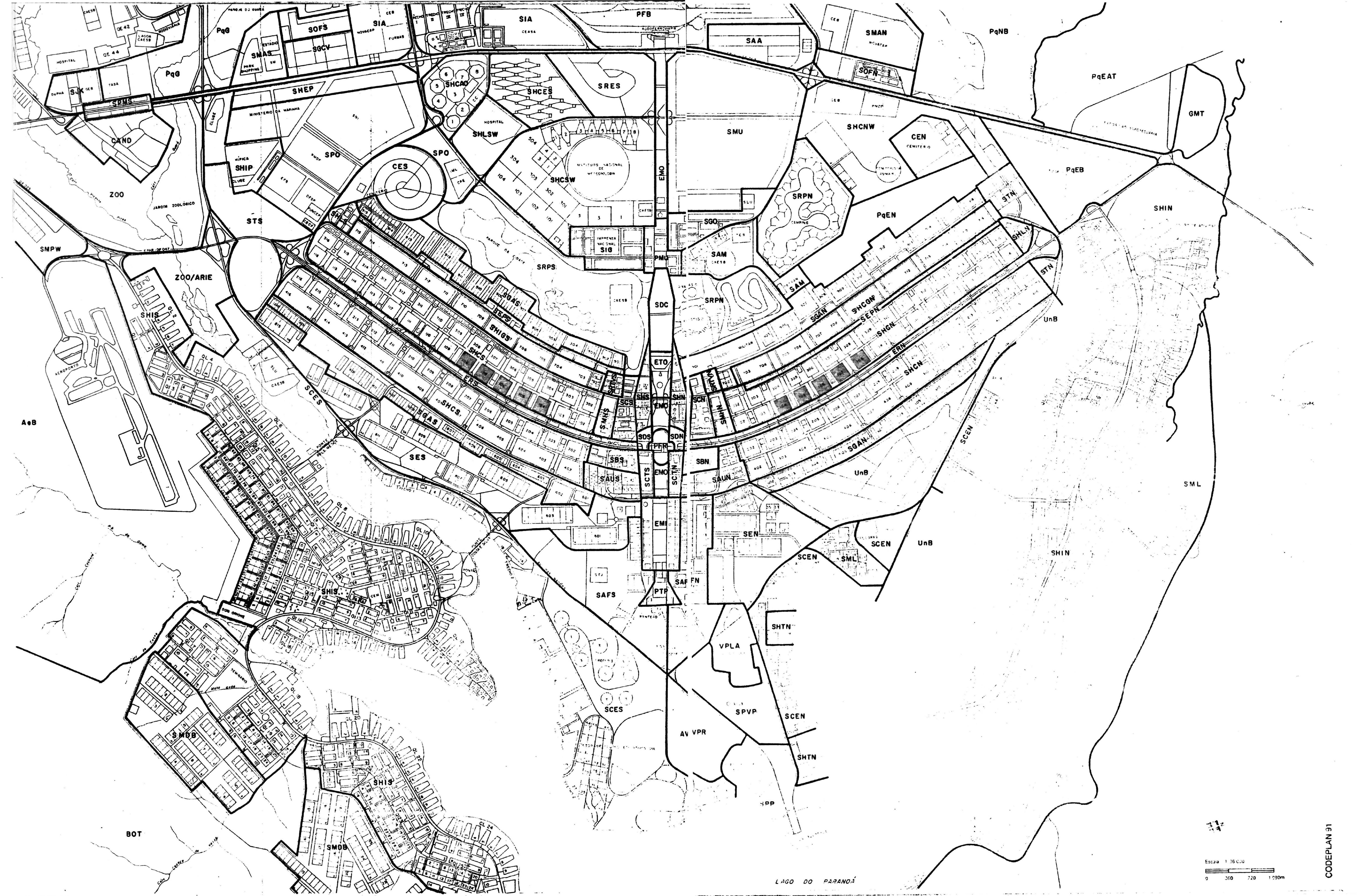


Anexo 2 - Questionário de Pesquisa - Ruído e a Qualidade Ambiental Urbana na Cidade de Brasilia - DF

1 - Você gosta de morar neste apartamento?

1) Eu gosto daqui

2) Tanto faz

3) Eu gostaria de mudar

4) Eu gostaria de mudar daqui o mais rápido possivel

2 - Quais os aspectos que você mais gosta nesta área em que mora atualmente?
1) Boa localizaçäo
2) Clima
3) Vista
4) Área Verde
5) Oferta de comércio
6) Ambiente da quadra
7) Segurança
8) Espaço urbano
9) Transporte coletivo
10) Limpeza
11) Tranquilidade do trânsito
12) Qualidade do apartamento
13) Outras
14) A cidade

3 - Quais os aspectos que você menos gosta nesta cidade?

1) falta de segurança

2) barulho

3) baixa qualidade dos serviços de transporte

4) clima

5) falta de espaço para andar 
6) dificuldade de entrosamento entre as pessoas

7) trânsito

8) violência

9) falta de praias

10) pouca opção de lazer

11) rigidez do plano da cidade

12) outras

13) não tem

4 - Como você avaliaria a qualidade do meio ambiente de sua cidade?
1) ruim
2) média
3) boa
4) ótima

5 - Como você avaliaria a qualidade do meio ambiente da área residencial ou bairro em que vive?
1) ruim
2)média
3)boa
4)ótima

6 - Como você avaliaria a qualidade do meio ambiente da área ou bairro que vocè vivia anteriormente comparando com a atual?

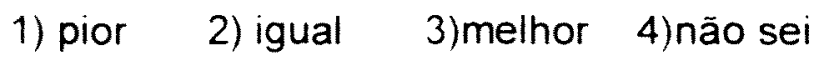

7- Avalie a situaçāo das caracteristicas abaixo relacionadas do bairro ou àrea que reside atualmente.

$\begin{array}{cccc}\text { Péssimo } & \text { Razoável } & \text { Bom } & \text { Ótimo } \\ 1 & 2 & 3 & 4 \\ 1 & 2 & 3 & 4 \\ 1 & 2 & 3 & 4 \\ 1 & 2 & 3 & 4 \\ 1 & 2 & 3 & 4 \\ 1 & 2 & 3 & 4 \\ 1 & 2 & 3 & 4 \\ 1 & 2 & 3 & 4\end{array}$

( ) Segurança

( ) Oferta de transporte

( ) Poluição do ar

( ) Ruido/barulho

( ) Tráfego

( ) Oferta de áreas verdes

( ) Oferta de espaços de lazer

( ) Limpeza urbana 
8 - Classifique os itens abaixo, em ordem numérica, segundo a prioridade que gostaria que fosse atendida, em uma área escolhida para morar.

( ) Segurança

( ) Ausência de Ruido/barulho

( ) Oferta de Transporte

( ) Qualidade do Ar

( ) Bom Tráfego

( ) Oferta de Áreas Verdes

( ) Oferta de Espaços de Lazer

( ) Limpeza Urbana

9 - Nos dias úteis da semana, quanto tempo em média você fica em casa durante o dia (entre as 8 e as $21 \mathrm{~h}$ )?
1) quatro a seis horas
2) sete a dez horas
3) mais de dez horas
4) todo o dia

10 - Nos dias de final de semana quanto tempo em média você fica em casa ou no seu bairro?
1) 4 a 6 horas
2)7 a 10 horas
3) mais de 10 horas
4)praticamente todo o dia

11 - Qual a sua sensibilidade ao baruiho/ruido?
1) alta
2) média
3) baixa

12 - Como você qualificaria seu apartamento quanto ao baruiho da rua?
1) muito baruihento
2) barulhento
3) moderado
4) silencioso

13- $O$ barulho do tráfego o assusta ?
1) $\operatorname{sim}$
2) não 
14 - O baruiho da rua faz com que você mantenha as janelas fechadas?
1) $\operatorname{sim}$
2) não

15 - O barulho do tráfego te incomoda?
1) $\operatorname{sim}$
2)กão

16 - Qual o nivel de incômodo?
1) pouco
2) médio
3) muito
4) nenhum

17 - Quais os dias em que você se sente mais incomodado pelo barulho do tráfego?
1) segunda a sexta
2) finais de semanas
3) todos os dias

4) nenhum

18 - Tem algum periodo especifico do dia em que 0 barulho 0 incomoda?
1) $\operatorname{sim}$
2)ทão

19 - Qual o periodo do dia que você se sente mais incomodado pelo barulho?
1) manhã
2) hora do almoço
3) final da tarde
4) noite
5) todos
6) nenhum

20 - Você diria que já esta acostumado com a intensidade do barulho do tráfego existente em sua residência?
1) $\operatorname{sim}$
2) nāo

21 - O ruido interfere em qualquer das atividades abaixo relacionadas? (dormir, assistir televisão, ouvir som, conversar, estudar, trabalhar)
1) $\mathrm{sim}$
2) não 
Caso tenha respondido sim na questão 21 responda às questōes 22 a 26 .

22 - Qual a atividade em que você se sente mais incomodado pelo ruido?
1) dormir
2) assistir TV
3) ouvir som
4) conversar
5) estudar
6) trabaihar
7) todas as atividades
8) outras
9) nenhuma

23 - Qual a freqüência com que o ruido interfere em ouvir rádio, TV ou som?
1) sempre
2)algumas vezes
3) nunca

24 - O barulho do tráfego atrapalha alguém quando esta lendo ou estudando?
1) $\mathrm{sim}$
2) não

25 - O barulho do tráfego faz com que aumente o tom de voz quando está falando com alguém no telefone?
1) $\mathrm{sim}$
2) não

26 - O barulho do tráfego atrapalha-o quando está tentando dormir ?
1) $\operatorname{sim}$
2) não

27- Você acha que o nivel de barulho/ruído que existe nesta área tenha causado alguma doença ou piorado de alguma forma a sua saúde?
1) $\operatorname{sim}$
2) não 
28 - Você acha que o nivel de barulho/ruído da rua que existe em sua área tenha atingido de alguma forma a saúde de alguém de sua familia?
1) $\operatorname{sim}$
2) não

29 - Como você acha que o nível de ruído/barulho da rua estará, no futuro, na área ou bairro em que mora atualmente?
1) maior e pior
2) mesmo nivel
3) reduzido e melhor
4) não sei

30 - Você acha que existem áreas residenciais em sua cidade que apresentam situações piores de barulho do que nesta em que vive?
1) $\operatorname{sim}$
2) nāo
3) não sei

31- Você acha que tem alguma forma de reduzir o nivel de barulho desta área em que reside?
1) $\operatorname{sim}$
2) não

Finalmente, eu gostaria de fazer algumas perguntas para caracterizar a amostra selecionada, sem fazer qualquer identificação pessoal.

32 - Há quanto tempo mora nesta área?
1) meses
2) 1 a 2 anos
3) 2 a 4 anos
4) 4 a 7 anos
5) > 7anos

33 - Andar do apartamento
1) $1^{\circ}$
2) $2^{\circ}$
3) $3^{\circ}$
4) $4^{\circ}$
5) $5^{\circ}$
6) $6^{\circ}$

34 - Quantos cômodos tem este apartamento (sem contar banheiros)?
1) $1 \mathrm{a} 3$
2) 4 a 6
3) 7 a 9 4) $>9$

35 - Quantos cômodos têm janelas para esta via de maior tráfego?
1) 1
2) 2
3) 3
4) 4
5) $>4$ 
36 - Quais são esses cômođos?

$\begin{array}{llll}\text { 1) sala 2) sala e quartos } & \text { 3) quartos 4) área de serviço } & \text { 5) outros }\end{array}$

37- Quantas pessoas residem neste apartamento?
1) 1 a 3
2) $4 a 6$
3) 7 a 8
4) $>8$

38 - Você trabalha em que periodo?
1) manhã
2) tarde
3) noite
4) integral
5) nenhum

39 - Ano de nascimento

19

40 - Nivel escolar?
1) primário
2) secundário
3) nivel superior
4) outros

41- Sexo
1) Masculino
2) Feminino 